UNIVERSIDADE DO EXTREMO SUL CATARINENSE (UNESC) UNIDADE ACADÊMICA CIÊNCIAS SOCIAIS APLICADAS

PROGRAMA DE PÓS-GRADUAÇÃO EM

DESENVOLVIMENTO

SOCIOECONÔMICO (PPGDS)

\author{
JANIR DE QUADRA PAIM
}

\title{
CONTRIBUIÇÕES DAS UNIVERSIDADES COMUNITÁRIAS DE SANTA CATARINA PARA O DESENVOLVIMENTO REGIONAL NA SOCIEDADE DO CONHECIMENTO
}
Dissertação apresentada ao Programa de Pós-Graduação em Mestrado da Universidade do Extremo Sul Catarinense - UNESC, como requisito parcial para a obtenção do título de Mestre em Desenvolvimento Socioeconômico.

Orientadora: Profa. Dra. Cristina Keiko Yamaguchi

Coorientador: Prof. Dr. Miguelangelo Gianezini 
Dados Internacionais de Catalogação na Publicação

P143c Paim, Janir de Quadra.

Contribuições das universidades comunitárias de Santa Catarina para o desenvolvimento regional na sociedade do conhecimento / Janir de Quadra Paim. - 2017.

159 p. : il.; $21 \mathrm{~cm}$.

Dissertação (Mestrado) - Universidade do Extremo Sul Catarinense, Programa de Pós-Graduação em

Desenvolvimento Socioeconômico, Criciúma, 2017.

Orientação: Cristina Keiko Yamaguchi.

Coorientação: Miguelangelo Gianezini.

1. Universidades comunitárias. 2. Universidades e faculdades. 3. Desenvolvimento regional. 4. Sociedade do conhecimento. I. Título.

CDD 23. ed. 378.155

Bibliotecária Eliziane de Lucca Alosilla - CRB 14/1101

Biblioteca Central Prof. Eurico Back - UNESC 


\section{JANIR DE QUADRA PAIM}

\section{CONTRIBUIÇÕES DAS UNIVERSIIADES COMUNITÁRIAS DE SANTA CATARINA PARA O DESENVOLVIMENTO REGIONAL NA SOCIEDADE DO CONHECIMENTO}

Esta dissertação foi julgada e aprovada para obtenção do Grau de Mestre em Desenvolvimento Socioeconômico no Programa de Pós-Graduação em Desenvolvimento Socioeconômico da Universidade do Extremo Sul Catarinense.

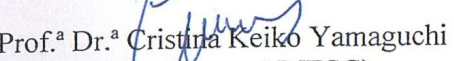

(Orientadora - UNESC)

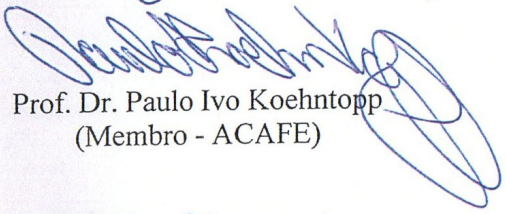

rof. Dr. Miguelangeto Gianezini

KELCY GIANEETIN

Prof. ${ }^{\text {a }}$. ${ }^{a}$ Kelly Gianezini

(Membro - UNESC)

Prof. ${ }^{\text {a Dr. }}{ }^{\text {a }}$ Adriana Carvalho Pinto Vieira (Coorientador -(UNESE)

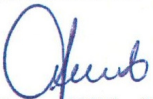

Prof. Dr. Gildo Volpato

(Membro - UNESC)

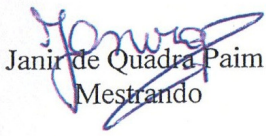

(Membro Suplente- UNESC)

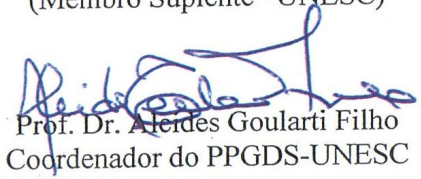



Este trabalho tem uma dedicatória a todos que de uma maneira ou de outra contribuíram para que pudesse concluí-lo. Mas de maneira especial à minha esposa pela paciência e tolerância em vários momentos que concedeu tempo necessário, abrindo mão de momentos de lazer, $e$, compreendendo a necessidade de término da pesquisa. Por ter se disponibilizado a me acompanhar em todas as viagens pelo estado para realização das entrevistas. Assim, com muito carinho dedico esta conquista à minha parceira de vida há mais de 20 anos, minha esposa Fabiana e aos meus filhos Jhenifer e Carlos Henrique. 



\section{AGRADECIMENTOS}

Agradeço à UNESC, ao ex-Reitor Prof. Dr. Gildo Volpato e à exPró-reitora Prof ${ }^{a}$. Kátia Aurora Dalla Libera Sorato, por oportunizar o curso de Mestrado nesta Instituição, onde trabalho com muita dedicação há treze anos, concedendo-me liberdade e flexibilização de horário para concluir com êxito o curso.

Aos professores do Mestrado em Desenvolvimento Socioeconômico que conheci nas disciplinas cursadas e que contribui para o meu aprendizado. Dentre eles destaco, de maneira muito especial, a professora Cristina Keiko Yamaguchi - minha orientadora - e ao professor Miguelangelo Gianezini - meu coorientador - por todas as contribuições e aprendizados que tivemos durante a execução do trabalho, pela paciência que tiveram comigo como orientando, compreendendo o meu tempo e meu trabalho profissional, como obstáculos de uma conclusão mais breve do trabalho.

E ainda, agradeço a todos os gestores das IES que visitei e que conseguiram abrir um espaço em suas agendas para me receber, e assim me concederam tempo para uma conversa e repasse de informações que contribuíram muito para o meu trabalho. Também não posso esquecer os dirigentes das ACI's que me receberam. Em quase todas as cidades que visitei fui recebido por um grupo de membros da associação, os quais me atenderam para as entrevistas, fato que enriqueceu grandemente a pesquisa.

E, por último, da mesma forma, agradeço aos membros da banca de avaliação da dissertação, aos Prof. Dr. Paulo Ivo, Prof. Dr. Gildo Volpato e Prof ${ }^{a}$. Dra. Kelly Gianezini, que aceitaram o convite para avaliar o trabalho e, contribuíram para a conclusão da dissertação.

Agradeço a todos com um Muito Obrigado. 

$O$ conhecimento e a informação são os recursos estratégicos para o desenvolvimento de qualquer país. Os portadores desses recursos são as pessoas.

Peter Drucker

Aprender $e$ difundir o conhecimento e a educação como agentes de mudança $e$ desenvolvimento social, é uma responsabilidade e obrigação de todo cidadão consciente.

Altivo Ferreira Filho 



\section{RESUMO}

PAIM, Janir de Quadra. Contribuições das universidades comunitárias de Santa Catarina para o desenvolvimento regional na sociedade do conhecimento. 2017, 108 f. Dissertação (Mestrado em Desenvolvimento Socioeconômico) - Programa de Pós-Graduação em Desenvolvimento Socioeconômico, UNESC, Criciúma, 2017.

As Instituições Comunitárias do Ensino Superior (ICES) do estado de Santa Catarina têm suas origens, a partir de uma política de Estado de interiorização do ensino superior, com o objetivo de promover o desenvolvimento local. Essas Instituições são reconhecidas como agentes propulsores do desenvolvimento regional, devido à interação com as comunidades regionais. Possuem um papel importante como agentes de desenvolvimento, por meio de ações que vão além da formação de qualidade, pois, formam cidadãos comprometidos com o desenvolvimento local e regional. As ICES contribuem para que o conhecimento $\mathrm{e}$ as informações compartilhadas promovam o desenvolvimento e crescimento econômico e social na sociedade do conhecimento. A dissertação objetivou evidenciar e avaliar a percepção da comunidade organizada sobre as ações desenvolvidas pela universidade e sua interação para o desenvolvimento regional catarinense. $\mathrm{O}$ estudo foi realizado junto as ICES caracterizadas como comunitárias, por meio de levantamento das ações de interação com a comunidade, bem como entrevistas com representantes das associações empresariais dos municípios onde estas ICES estão inseridas. A pesquisa foi caracterizada como uma pesquisa de natureza interdisciplinar e quanto aos procedimentos metodológicos foi classificada como descritiva, exploratória, de métodos mistos (qualiquanti), com concepções construtivistas. Fez-se uso do Índice de Inserção Regional das Universidades Catarinenses (IIR), para identificar o caráter comunitário das ICES catarinenses escolhidas, avaliando suas características e suas ações perante a comunidade onde estão inseridas. Constatou-se que, de maneira indireta, as ICES promovem o seu entorno com novos empreendimentos comerciais e imobiliários. As entrevistas com gestores de seis universidades do sistema ACAFE, mostraram que as universidades interagem com sua comunidade por meio de atividades esportivas, culturais e de saúde, necessitando melhorar as relações com o setor empresarial. Do outro lado, o setor empresarial reconhece as instituições de ensino por suas atividades de ensino, porém, afirmam 

que estas devem ultrapassar seus muros e se aproximar do setor produtivo para que juntos possam promover o desenvolvimento e o crescimento econômico das regiões onde atuam, para assim contribuírem com mudanças na sociedade, principalmente no tocante ao processo produtivo. Nesse contexto, a maior contribuição dessa pesquisa ocorreu pela constatação da pouca visibilidade das ações de extensão com o compromisso social para a sociedade do conhecimento. Há a necessidade de melhorar o processo de parceria entre a universidade e empresa, por meio de diálogos e convivência, até alcançar a identificação cultural e a confiança. Constata-se que parte das universidades focam na pesquisa, na extensão assistencialista, e não resolvem as reais necessidades para o desenvolvimento produtivo e mudanças tecnológicas.

Palavras-chave: Universidades comunitárias. Sociedade do conhecimento. Desenvolvimento regional. 



\section{ABSTRACT}

PAIM, Janir de Quadra. Contribuições das universidades comunitárias de Santa Catarina para o desenvolvimento regional na sociedade do conhecimento. 2017, 108 f. Dissertação (Mestrado em Desenvolvimento Socioeconômico) - Programa de Pós-Graduação em Desenvolvimento Socioeconômico, UNESC, Criciúma, 2017.

The Community Institutions of Higher Education (ICES) of the State of Santa Catarina, have their origins from a state policy, internalization of higher education with the objective of promoting the development of the interior of the state. These institutions are recognized as agents of regional development due to interaction with regional communities. They have an important role as agents of development, through actions that go beyond technical quality training, because they are citizens committed to local and regional development. The ICES contributes to shared knowledge and information promoting economic and social development and growth in the knowledge society. Thus, the present work aims to evidence and evaluate the perception of the organized community about the actions developed by the university and its interaction for the regional development of Santa Catarina. The study was carried out with ICES characterized as community, by means of a survey of community interaction actions, as well as interviews with representatives of the Business Associations of the municipalities where these ICES are inserted. Characterized as a research of an interdisciplinary nature, as far as the methodological procedures is classified as descriptive, exploratory, of mixed methods (quali-quanti), with constructivist conceptions. The Regional Insertion Index of the Catarinenses Universities (IIR) will be used to identify the community character of the chosen ICAS from Santa Catarina, evaluating their characteristics and their actions before the community where they are inserted. It was found that, indirectly, the ICES promote their surroundings with new ventures, be they commercial and real estate. In the interviews with managers of 06 universities of the ACAFE system, they show that universities interact through sports, cultural and health activities, needing to improve relations with the business sector. On the other hand, the business sector recognizes educational institutions for their teaching activities; however, they affirm that educational institutions must go beyond their walls and approach the productive sector so that together they can promote the development and economic 

growth of regions where They act. In order to contribute to changes in society, especially in relation to the productive process. In this context, the greatest contribution of this research is given by the lack of visibility of the extension actions with the social commitment to the knowledge society. There is a need to improve the partnership process between the university and the company, through dialogues and coexistence until cultural identification and trust are achieved. It is noticed that a great part of the universities focus on the research and extension in the assistencialismo, and they do not solve the real necessities for the productive development and technological changes.

Keywords: Community universities. Knowledge society. Regional development. 



\section{LISTA DE QUADROS}

Quadro 01 - Instituições de Ensino da ACAFE.................................... 46

Quadro 02 - Eixos de avaliação do SINAES ........................................ 66

Quadro 03 - Composição do IDMS ................................................. 91

Quadro 04 - Classificação do IDMS ................................................. 92

Quadro 05 - Média dos Índices IDMS dos Municipios ........................ 93

Quadro 06 - IDEMS das messoregiões de Santa Catarina.................... 93

Quadro 07 - Características dos municípios visitados .......................... 95

Quadro 08 - Indicadores dos municípios visitados ...............................96

Quadro 09 - Índice calculado das ICES do Sistema ACAFE ............... 98

Quadro 10 - Categoria 01- Contribuição da Pesquisa a Inovação

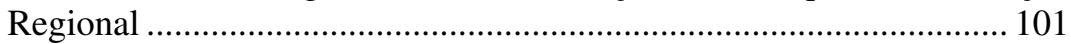

Quadro 10.1 - Categoria 01- Contribuição da Pesquisa a Inovação

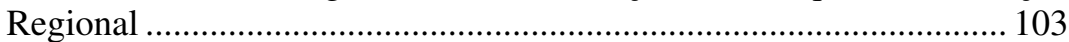

Quadro 10.2 - Análise da Categoria 01- Contribuição da Pesquisa a

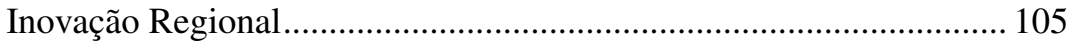

Quadro 11 - Categoria 02 - Contribuição do Ensino e Aprendizado ao Mercado de Trabalho e à Profissionalização. 106

Quadro 11.1 - Categoria 02 - Contribuição do Ensino e Aprendizado ao Mercado de Trabalho e à Profissionalização....................................... 107 Quadro 12 - Análise da Categoria 03 - Contribuição do Ensino e Aprendizado ao Mercado de Trabalho e à Profissionalização ............ 108 Quadro 13 - Categoria 03 - Contribuição ao Desenvolvimento Social, Cultural e Ambiental ..................................................................... 110

Quadro 13.1 - Categoria 03 - Contribuição ao Desenvolvimento Social, Cultural e Ambiental

Quadro 13.2 - Análise Categoria 03 - Contribuição ao Desenvolvimento Social, Cultural e Ambiental ............................................................ 113

Quadro 14 - Categoria 4 - Capacitação para a Cooperação Regional. 114 Quadro 14.1 - Categoria 4 - Capacitação para a Cooperação Regional

Quadro 14.2 - Análise Categoria 04 - Capacitação para a Cooperação Regional 



\section{LISTA DE FIGURAS}

Figura 01 - Abordagem sistêmica da responsabilidade social das IES. 55

Figura 02 - Impactos regionais de uma universidade 56

Figura 03 - IES multimodais e multiescalares comprometidas regionalmente.

Figura 04 - Modelo teórico - inserção da tríade ensino pesquisa

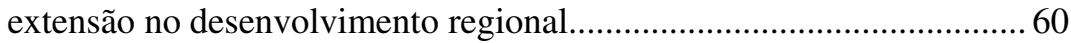

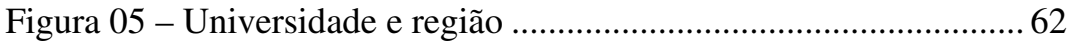

Figura 06 - Relação entre universidade e região................................... 68

Figura 07 - Mapa do estado de Santa Catarina com as universidades da

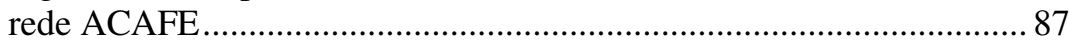

Figura 08 - Distribuição dos índices em relação à Média Calculada.... 99 Figura 09 - Abordagem sistêmica da responsabilidade social das IES121

Figura 10 - Impactos regionais de uma universidade ......................... 122

Figura 11 - Modelo teórico - inserção da tríade ensino, pesquisa e extensão no desenvolvimento regional............................................... 123

Figura 12- Universidade e região .................................................. 124

Figura 13 - Relação entre universidade e região................................ 124 



\section{LISTA DE ABREVIATURAS E SIGLAS}

ABIEE Associação Brasileira de Instituições Educacionais Evangélicas ABRUC Associação Brasileira das Universidades Comunitárias ACAFE Associação Catarinense das Fundações Educacionais AMESC Associação dos Municípios do Extremo Sul Catarinense

AMFLIAssociação dos Municípios da Região da Foz do Rio Itajaí AMREC Associação dos Municípios da Região Carbonífera AMUREL Associação de Municípios da Região de Laguna AMURES Associação dos Municípios da Região Serrana ANEC Associação Nacional de Educação Católica do Brasil ANUP Associação Nacional das Universidades Particulares CAPESCoordenação de Aperfeiçoamento de Pessoal de Nível Superior CDL Câmara de Dirigentes Lojistas

COMUNG Consórcio das Universidades Comunitárias Gaúchas CONSAD Conselho Superior de Administração IBAMA Instituto Brasileiro do Meio Ambiente e dos Recursos Naturais Renováveis

ICES Instituições Comunitárias de Educação Superior IDEMSÍndice de Desenvolvimento Econômico Municipal Sustentável IES

IIR Instituição de Ensino Superior INEP Instituto Nacional de Estudos e Pesquisa

LDB Lei de Diretrizes e Bases da Educação

MEC Ministério da Educação e Cultura

NIT Núcleo de Inovação Tecnológica

OMS Organização Mundial de Saúde

ONU Organização das Nações Unidas

P\&D Pesquisa e Desenvolvimento

PPGDSPrograma de Pós-graduação em Desenvolvimento Socioeconômico

PPGs

PUC

SINAES

SUS
Programa de Pós-graduação Stricto Sensu

Pontifícia Universidade Católica

Sistema Nacional de Avaliação da Educação Superior Sistema Único de Saúde 



\section{SUMÁRIO}

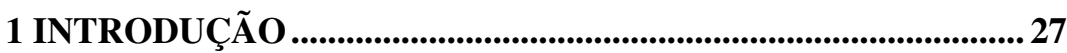

1.1 TEMA, PROBLEMA E QUESTÃO DE PESQUISA ………….......2 28

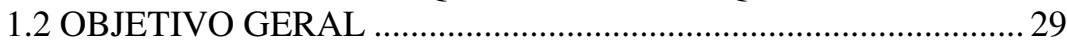

1.2.1 Objetivos específicos .........................................................................30

1.3 JUSTIFICATIVA .................................................................. 30

2 UNIVERSIDADE E DESENVOLVIMENTO.................................33

2.1 CONSTITUIÇÃO E CARACTERÍSTICAS DAS ICES NO BRASIL E EM SANTA CATARINA …………………………......... 33

2.1.1 As universidades comunitárias Catarinenses ............................. 43

2.1.2 Reconhecimento como universidade comunitária .....................49

2.2 AÇÕES DAS INSTITUIÇÕES COMUNITÁRIAS DE ENSINO SUPERIOR QUE PROMOVEM O DESENVOLVIMENTO SOCIOECONÔMICO REGIONAL ……………………………….....52

2.2.1 Desenvolvimento Regional...............................................................52

2.2.2 Ações promovidas pelas ICES que contribuem com o desenvolvimento regional .........................................................................64

2.3 SOCIEDADE DO CONHECIMENTO.......................................... 70

3 PROCEDIMENTOS METODOLÓGICOS ………………............... 78

3.1 ENQUADRAMENTO METODOLÓGICO …………………......... 78

3.2 CÁLCULO DO ÍNDICE DE INSERÇÃO REGIONAL DAS ICES

.

3.3 METODOLOGIA DE CÁLCULO DO IIR APLICADO ………...... 84

3.4 PROCEDIMENTOS DE COLETA DE DADOS ……………......... 87

3.4.1 Os percalços e dificuldades no caminho ....................................... 88

3.5 CATEGORIAS DE ANÁLISE ……………………………....... 99

3.6 JUSTIFICATIVA DA ESCOLHA DOS LOCAIS DE PESQUISA90

4 APRESENTAÇÃO DOS DADOS......................................................98

4.1 ANÁLISE DASS ENTREVISTAS …………………….............. 99

4.2 ANÁLISE DOS DADOS DA PESQUISA ……………………...... 121

5 CONSIDERAÇÕES FINAIS ............................................................. 127

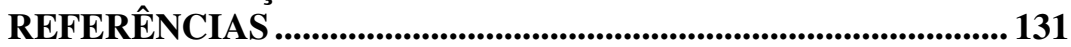

APÊNDICE(S) ........................................................................................ 139

APÊNDICE A: CARACTERÍSTICAS E PERCEPÇÕES DETECTADAS NAS ENTREVISTAS .............................................. 141

ANEXOS …............................................................................................ 155

ANEXO A …….............................................................................................. 157

ANEXO B........................................................................................ 158

ANEXO C: PLANILHA DE COLETA DE INFORMAÇÕES..... 159 



\section{INTRODUÇÃO}

As Instituições de Ensino Superior exercem papel importante para o desenvolvimento da sociedade atuando como agentes de formação, não apenas na questão técnica, mas, formando cidadãos comprometidos com o crescimento e a melhoria das relações de vida em sociedade.

As Universidades Comunitárias passaram a existir, a partir do resultado de um esforço de comunidades regionais para construírem seus espaços de ascensão social, tendo em vista a não oferta por parte do Estado de condições para tal. Com as transformações econômicas, políticas e sociais, têm-se a expectativa de mobilização de setores da sociedade para uma melhor qualidade de vida, por meio da educação (FRANTZ, 2004).

No Brasil, a origem das instituições de ensino foi diversificada e de acordo com as características regionais em que surgiram. Durante o período de sua evolução, passaram por diversas formatações. No sul do Brasil, em decorrência do espírito comunitário, nasceram no Rio Grande do Sul, as Escolas Comunitárias, Instituições de Ensino estas, que tiveram raízes religiosas, porém não se restringiram somente aqueles interesses e nem foram assistidos financeiramente pelas instituições religiosas (VOGT, 2009).

No estado de Santa Catarina, as universidades comunitárias foram constituídas a partir de preocupações dos diversos segmentos sociais em alavancar o desenvolvimento regional. Sendo estes empreendimentos resultados da associação de esforços dos segmentos sociais, que envolvem o poder público municipal e as entidades organizadas da sociedade civil, que mantinham preocupação em proporcionar o desenvolvimento regional na área social, econômica e cultural, devido à sua localização ser em regiões pouco assistidas pelos poderes públicos estaduais e federais (MACHADO, 2009).

As universidades comunitárias foram criadas pela sociedade civil ou por leis municipais, com gestão democrática e participativa, em favor da inclusão social e do desenvolvimento regional. Exercem um papel significativo na difusão do conhecimento nas regiões onde atuam; seja por intermédio dos cursos de graduação, pós ou extensão, conseguem contribuir com o desenvolvimento da região em que estão inseridas.

Cavichioli (2011) entende que as universidades podem agir e ser um dos agentes facilitadores do desenvolvimento, por intermédio das diversas maneiras de interação com a comunidade em seu entorno. Podem contribuir de maneira significativa para que o conhecimento e as 
informações compartilhadas consigam promover o desenvolvimento e o crescimento econômico, ambiental e social, das regiões em que atuam.

Atualmente, se vivencia o momento de valorização do conhecimento, o qual permite o entendimento da evolução das organizações sociais, políticas e econômicas. Assim, o sucesso neste cenário permeia em saber capturar as informações, questioná-las, organizá-las e tecer críticas, bem como, saber empregá-las, de modo a responder a algum problema atual, papel que as instituições de ensino superior devem contribuir de maneira significativa para que aconteça (GUIMARÃES; MAGALHÃES, 2016).

Para Bernheim e Chauí (2008), a universidade deve retribuir o investimento que recebe da comunidade, desenvolvendo em estudos, pesquisas e projetos de extensão, compatíveis com as reais necessidades da população, em benefício comum e, contribuir para solucionar os atuais problemas da sociedade. Outra função da universidade é auxiliar os alunos para que eles tenham uma opinião formulada e crítica diante da realidade social, para que haja um avanço científico, tecnológico e cultural.

Da mesma forma, Silva e Melo (2010), mostram que a universidade desenvolve várias ações de extensão com compromisso social. No entanto, a extensão ainda é uma função que não tem tanta visibilidade quanto o ensino e a pesquisa, necessitando de mais apoio, consciência da comunidade universitária, reconhecimento e incentivos, para que as três funções se tornem realmente um tripé da universidade. Ainda que nem toda a extensão seja uma ação de compromisso social, há projetos de destaque, que incorporam o sentido de transformação da sociedade, de desenvolver emancipação social, de melhora da qualidade de vida da população.

\subsection{TEMA, PROBLEMA E QUESTÃO DE PESQUISA}

As universidades comunitárias estão centradas na missão acadêmica e de prestação de serviços à comunidade do seu entorno, para que possam justificar sua existência e o crescimento nos dias atuais. E para consolidar uma identidade própria que as auxilie a desempenhar com eficiência a missão educacional a que se propõem, enfatizam o trabalho em ações sociais que seriam de responsabilidade das instituições públicas, ações estas que as universidades comunitárias vêm desempenhando (VENANZI; SANDANO, 2014).

As universidades comunitárias procuram fortalecer seus ideais, voltados para as questões de responsabilidade social, tanto na formação 
de cidadãos (objetivo maior das universidades) quanto na identificação de problemas da comunidade e desenvolvimento regional. Nesse sentido, tem papel fundamental na interação com as comunidades locais e regionais, bem como de auxiliar na busca por resultados mais concretos para o desenvolvimento institucional e social (VENANZI; SANDANO, 2014).

Distintos autores (ROSA-CASTRO; MARQUES JUNIOR; MARQUES, 2014; VENANZI; SANDANO, 2014) afirmam que o papel principal das universidades comunitárias é a relação do ensino com a aprendizagem, um processo de "humanização do conhecimento", na medida em que se propõe a compartilhar os conhecimentos produzidos com a comunidade ao seu redor. As universidades comunitárias possuem o compromisso social e precisam redobrar os esforços, em parceria com as comunidades, para avançar em seu fortalecimento e prestar um serviço para a comunidade. A identidade das universidades comunitárias vem sendo construída como segmento diferenciado e, ao mesmo tempo, inovador, sempre com o intuito de se tornarem conhecidas como um modelo alternativo de Educação Superior.

A partir da Lei das Comunitárias, ${ }^{1}$ as ICES são alçadas para uma nova condição, com novas oportunidades e novos desafios, os quais podem ser considerados em suas estratégias de desenvolvimento e continuidade, como agentes promotores do desenvolvimento regional, pela sua origem social e relação histórica e conceitual com a comunidade. Assim, questiona-se, como a comunidade organizada percebe a interação regional das ICES catarinenses para o desenvolvimento regional na sociedade do conhecimento?

Para alcançar a reposta ao problema proposto, se estabeleceram os objetivos a seguir:

\subsection{OBJETIVO GERAL}

Compreender a percepção da comunidade organizada acerca da interação regional das ICES catarinenses para o desenvolvimento regional na sociedade do conhecimento.

\footnotetext{
${ }^{1}$ Lei no 12.881 , Lei das Instituições Comunitárias de Educação Superior publicada em 12 de novembro de 2013.
} 


\subsubsection{Objetivos específicos}

1) Caracterizar as ICES, incluindo o seu histórico de constituição em Santa Catarina;

2) Descrever as diferentes ações realizadas pelas ICES, que podem contribuir com o desenvolvimento socioeconômico regional;

3) Avaliar as percepções da comunidade organizada sobre as atuações das ICES para o desenvolvimento socioeconômico regional na sociedade do conhecimento; e,

4) Investigar se as universidades da ACAFE possuem características semelhantes e se estão correspondendo às expectativas de interação da sociedade regional em que atuam.

\subsection{JUSTIFICATIVA}

As ICES em sua maioria estão localizadas no sul do País, principalmente nos estados de Santa Catarina e Rio Grande do Sul. E em Santa Catarina estão associadas à ACAFE, na qual conseguem conduzir suas estratégias comuns, para a sustentabilidade econômica e financeira das instituições.

No ano de 2012, após a luta de mobilização nacional, as instituições conseguiram aprovar a lei $\mathrm{n}^{\circ} 12.881$, chamada de Lei das Comunitárias, a qual as reconheceu como Instituições de Educação Superior (IES) voltadas ao desenvolvimento socioeconômico regional. Porém, para que possam alcançar o termo de outorga, necessitam da comprovação de uma série de exigibilidades descritas na referida Lei. Algumas ICES conseguiram com facilidade tais critérios. Cabe destacar que a UNESC, Instituição em que trabalho há mais de treze anos, foi uma delas.

Assim, o fato de trabalhar em uma ICES e ter, desta maneira, acompanhado o crescimento não apenas estrutural, mas de maturação na forma de gestão da IES, e, ainda, por ter acompanhado parte das demandas da ACAFE em conjunto com o Consórcio das Universidades Comunitárias Gaúchas (COMUNG), a Associação Brasileira das Universidades Comunitárias (ABRUC) e outras entidades que representaram as instituições na luta junto ao congresso nacional, e, posterior aprovação do senado, do reconhecimento das ICES, fez surgir o interesse de pesquisar mais sobre estas universidades que representam um elo para o crescimento e o desenvolvimento regional. 
As ICES desenvolvem um conjunto de atividades voltadas ao ensino, pesquisa e extensão, com envolvimento na comunidade regional. Por intermédio destas instituições, muitas pessoas passam a ter acesso aos serviços sociais com mais qualidade - como exemplo citam-se os atendimentos realizados nas clínicas de saúde e odontológicas, as quais são mantidas pelas ICES como local de estágios dos cursos da área da saúde. Também promovem atendimentos na área jurídica, assessorias, prestações de serviços e diversas atividades de extensão, que envolvem a comunidade local, das mais variadas classes sociais.

Os programas de pós-graduação stricto sensu, os quais possuem grupos de pesquisa nas mais variadas áreas do conhecimento e nos quais desenvolvem-se os mais diversificados tipos de pesquisa. Tais grupos são liderados por professores qualificados, que produzem seus trabalhos de pesquisa com a contribuição dos alunos bolsistas (iniciação científica, mestrado e doutorado) para a promoção do desenvolvimento regional, social, econômico e ambiental.

As ICES são reconhecidas como instituições filantrópicas, por não terem como objetivo fim, a obtenção de ganhos financeiros para distribuição entre sócios. Por serem fundações criadas pelo poder público municipal, todos os resultados econômicos financeiros são revertidos para ampliação e manutenção do patrimônio existente, e, em caso de solvência da instituição, o patrimônio é destinado ao poder público.

$\mathrm{Na}$ instituição em que trabalho se visualiza a interação da universidade e a comunidade, seja ela local ou regional, por intermédio das diversas ações promovidas via projetos de pesquisa e extensão, além de atividades promovidas abertas à comunidade em geral. ${ }^{2}$ Característica esta, que se encontra na missão de quase todas as ICES da ACAFE, pois existe um esforço conjunto para desenvolver estratégias direcionadas para que cada vez mais estejam se integrando ao meio social, no qual estão estabelecidas.

Porém, apesar de todas as atividades e esforços empregados pelas ICES para promoção da integração com a comunidade e com o desenvolvimento do seu entorno, permanece a dúvida se realmente o que estão fazendo é o que a comunidade espera. Se as estratégias de interação estão alcançando o resultado esperado pela comunidade e pelas próprias ICES.

O trabalho está dividido em capítulos, de modo a caracterizar, primeiramente, a origem das universidades brasileiras e suas influências,

${ }^{2}$ Para saber mais vide a dissertação de mestrado de Fabrizio Guinzani. 
bem como a origem e formação das ICES, de maneira a conhecer um pouco sobre as características originárias destas instituições que aparentemente tanto fazem pela comunidade regional. Na segunda parte do trabalho foi demonstrado, por intermédio de pesquisas já publicadas, quais são as formas de interação das Instituições de Ensino Superior, assim como a importância estratégica, como agentes contribuintes para o desenvolvimento socioeconômico regional. No capítulo final foi apresentado um resumo descritivo das informações coletadas nas entrevistas e, o resultado da pesquisa com as percepções em relação à importância das ICES para o desenvolvimento regional, no qual constatou-se que são comuns para os gestores das universidades e para a comunidade organizada, destacando-se as principais características encontradas no conjunto de instituições visitadas. 


\section{UNIVERSIDADE E DESENVOLVIMENTO}

Neste capítulo consta o histórico da origem e formação das ICES em Santa Catarina, por meio de referências bibliográficas. A trajetória histórica destas instituições localizadas no Sul do Brasil, em especial em Santa Catarina, até a aprovação da Lei $\mathrm{n}^{\circ} 12.881$, de 12 de novembro de 2013, que reconhece oficialmente as ICES.

\subsection{CONSTITUIÇÃO E CARACTERÍSTICAS DAS ICES NO BRASIL E EM SANTA CATARINA}

O ensino superior possui papel relevante no desenvolvimento socioeconômico de uma nação. Por meio do conhecimento é possível alcançar melhores alternativas de vida em comunidade e condições sociais mais uniformes à sociedade. As IES, presentes nas comunidades regionais são responsáveis pela formação de profissionais técnicos, com bom nível de conhecimento, também pensadores, cientistas, empreendedores e governantes do futuro, formuladores de inovação e inventores de utopias (MELO, 2011).

O Brasil teve o desenvolvimento do ensino superior caracterizado pelas influências trazidas por estes colonizadores. Volpato (2011, p. 680), afirma que "até 1808, os lusos brasileiros faziam seus estudos superiores na Europa, principalmente em Coimbra, Portugal." Com a chegada de D. João VI ao Brasil, foram instituídas as faculdades isoladas, nascendo assim, os cursos, as academias, com objetivo de dar respostas às necessidades da colônia, advindas da corte no Rio de Janeiro (VOLPATO, 2011).

Do período colonial até a primeira república, o Brasil não manifestava qualquer sinal de interesse em oferecer educação superior pública e gratuita para o seu povo. Isso forçou o surgimento das comunidades religiosas, as quais, por sua vez, criaram escolas com objetivo de ensinar a ler e escrever. Embora esta dissertação possua foco em Santa Catarina, há que se destacar, que esta foi uma das características da origem das universidades no estado do Rio Grande do Sul, pois com a falta de um sistema educacional gratuito, os imigrantes alemães, a partir de 1824 , começaram a criar o seu próprio sistema, o qual foi marcado pela religião e pela vivência em comunidade. $\mathrm{O}$ espírito comunitário é parte integrante da história de colonização do Sul do Brasil (SCHNEIDER, 2008).

A iniciativa comunitária na educação está vinculada às necessidades que os imigrantes de origem alemã enfrentaram no Brasil, 
numa época em que o ensino primário não era prioridade. Oriundos dos países da Reforma Protestante, esses imigrantes traziam a concepção luterana, firmada desde o século XVI, segundo a qual, a educação era encarada como obrigação em dois sentidos: do Estado, pela garantia da oferta; e da família, pelo envio dos filhos à escola. Uma vez aqui, num país sem escolas, os grupos que formaram as colônias teuto-brasileiras, ressentindo-se dessa ausência, lançaram mão da criação das escolas comunitárias, temendo que seus filhos crescessem "como caboclos" (BITTAR, 2009).

Em 1900, o ensino superior brasileiro possuía faculdades ou escolas superiores. Neste período a criação de universidades enfrentava dificuldades, devido ao ideário positivista que orientava a fase política daquele momento. Mas, no final da primeira república, o Brasil possuía cerca de 200 estabelecimentos de ensino superior, considerando as escolas de formação militar e teológica e duas universidades. Porém, devido ao processo de desenvolvimento econômico, iniciado a partir de 1920, e acelerado nas décadas seguintes, propiciou que no início de 1960 ocorresse grande demanda de mão de obra especializada. Assim, ocorreu uma expansão do ensino superior, e, no período de 1945 a 1960 foram criadas mais de 223 IES (VOLPATO, 2011).

Ainda de acordo com Volpato (2011, p. 684):

Durante a nova república, 22 novas universidades federais foram criadas, onde cada um dos estados da federação passou a contar com pelo menos, uma universidade federal localizada na capital, e neste período também foram criadas oito universidades católicas e uma presbiteriana.

Em 1968, o governo militar que comandava o Brasil, tendo os estudantes universitários como um foco de oposição, acabou por destruir o movimento estudantil da época, e encaminhou proposta de reforma do ensino superior do país. A proposta continha: extinção da cátedra; fim da autonomia das faculdades; criação de institutos, faculdades e/ou escolas; introdução do sistema de créditos; ciclo básico antes da formação profissional; garantia da representação discente e docente; ingresso contínuo por carreiras e currículos mínimos fixados pelo MEC (não à flexibilização) (SANTOS; CERQUEIRA, 2009).

Com a reforma de 1968, o ensino superior no Brasil passou a sofrer influência do modelo estadunidense, e, a partir de então, os três fins da universidade - a investigação, a cultura e a verdade, foram 
redefinidos e passaram a ser: a investigação, o ensino e a prestação de serviço (VOLPATO, 2011). Para Volpato (2011 p. 686), "a reforma de 1968 refletiu o alinhamento da educação superior ao modelo econômico, vinculado à internacionalização do capital sustentado pelo governo militar."

No período após a reforma proposta pelos militares ocorreu, a ampliação de acesso nos cursos já tradicionais e na organização de rede federal e estimulou a pesquisa e qualificação pela CAPES e CNPQ. Também foi criado um programa modular de apoio à pós-graduação e à pesquisa e a introdução do regime de tempo integral para docentes (SANTOS; CERQUEIRA, 2009).

De acordo com Santos e Cerqueira (2009, p. 6):

Apesar da proposta, a reforma foi incompleta; não houve verdadeira reforma curricular e a ampliação do sistema se deu simplesmente através da multiplicação da matrícula nos mesmos cursos tradicionais. A reforma tentou organizar todo o sistema federal em universidades e de promover a pesquisa, o que ia ao encontro das reivindicações dos estudantes e constava do ideário modernizador desde 1930.

Com o que ficou conhecido como milagre econômico na década de 1970, devido aos resultados ocasionados pelo desenvolvimento da economia no país, a classe média conseguiu ser beneficiada diretamente, ocasionando o aumento pela demanda ao ensino superior e o aumento do orçamento da união destinado à educação. No Brasil, a repressão política ocasionou o crescimento da demanda pelo ensino superior, e os números de matrículas em vinte anos passaram de 95.961, em 1960, para 134.500, em 1980 (SANTOS; CERQUEIRA, 2009).

De acordo com Santos e Cerqueira, (2009, p. 6):

O aumento da demanda por ensino superior está associado ao crescimento das camadas médias e às novas oportunidades de trabalho no setor mais moderno da economia e da tecnoburocracia estatal. O setor público não se preparou para esse momento do ensino superior. Já o setor privado foi capaz de absorvê-lo, porque se concentrou na oferta de cursos de baixo custo e no estabelecimento de exigências acadêmicas 
menores, tanto para o ingresso como para o prosseguimento dos estudos até a graduação.

Assim devido à reforma no sistema de educação do país, ocorreu o crescimento desordenado de instituições de ensino superior, tendo em vista que o Conselho Federal de Educação (CFE) reduziu as exigências. Volpato (2011, p. 687) explica que, "esta expansão fez com que, no ano de 1980, mais da metade dos alunos de terceiro grau estivesse matriculada em estabelecimentos isolados de ensino superior, sendo $86 \%$ em faculdades privadas". Neste contexto, ocorreram evoluções nas IES na última metade do século $\mathrm{XX}$, tanto no que diz respeito ao seu significado social, quanto às suas estruturas internas, e em suas relações com os outros agentes sociais econômicos, ocorrendo modificações nestes aspectos (ZABALZA, 2004).

Os aspectos conjunturais contribuíram para que o segmento comunitário encontrasse ressonância junto à força de sua organização. A própria diversificação e a heterogeneidade das instituições componentes do sistema de ensino superior brasileiro, possibilitaram as bases para que as IES comunitárias buscassem o seu próprio espaço. A isso acrescenta-se o fato do governo federal ter desencadeado sucessivos cortes na ajuda financeira que até a década de 1970 eram beneficiárias as universidades comunitárias, especialmente as confessionais-católicas (BITTAR, 2009).

Dentre as iniciativas, nasceu e se estruturou uma organização 'nova', contendo novas forças e novos significados sociais, que as diferencia das demais universidades, autodenominada de universidade comunitária, experiência fundante de uma natureza pública não estatal (FRANTZ, 2004). Assim, buscando diferenciar-se do chamado ensino privado "empresarial" ou "comercial", os representantes das universidades comunitárias passaram a denominar suas instituições como "públicas não-estatais", indicando que este seria o aspecto inovador de suas propostas: pelo fato de prestarem um serviço público caracterizado pelos trabalhos sociais desenvolvidos junto às populações de baixa renda - buscando aproximar-se do setor público estatal, distanciando-se do segmento estritamente particular (BITTAR, 2009).

Além disso, algumas dessas instituições, detentoras de significativas experiências na educação e, tendo consolidados programas de pós-graduação reconhecidos nacionalmente - como a PUC de São Paulo, PUC do Rio Grande do Sul e a PUC do Rio de Janeiro necessitavam garantir a sua própria sobrevivência institucional; portanto, a necessidade de uma luta mais corporativa se tornava uma 
questão premente. Desta maneira, na primeira metade da década de 1980, a denominação universidade comunitária começou a ser divulgada por representantes desse segmento, imbuídos de criar uma nova organização, já que, até então, a Associação Nacional das Universidades Particulares (ANUP) congregava todas as instituições não pertencentes ao setor público (BITTAR, 2009).

A denominação de públicas não-estatais, fez com que as universidades comunitárias buscassem um espaço que não pertencia exclusivamente ao público, e nem seria exclusivo do privado. Nesta tensão, em que as instituições possuem características de instituições públicas, devido às atividades de pesquisa, extensão, possuindo interação com a comunidade, apresentam também, características de privadas, devido à cobrança de mensalidades. É por essa razão que se configura o processo de construção da identidade das universidades comunitárias (BITTAR, 2009).

A Constituição Federal contemplou a demanda das entidades católicas, quando inseriu a categoria das escolas comunitárias no texto constitucional com a possibilidade de transferências de recursos públicos para escolas comunitárias, confessionais ou filantrópicas que comprovem finalidade não lucrativa, e que apliquem os resultados financeiros na educação. Como exigência se fazia necessário assegurar que o patrimônio seria da escola congênere em caso de encerramento de suas atividades, e, para a educação superior, existia a exigência de que os recursos deveriam ser aplicados em pesquisa e extensão (SCHIMDT, 2010).

Deste modo, o uso para definir universidades comunitárias é empregado na prática, tanto pelo grupo das universidades confessionais, quanto pelas oriundas da organização de comunidades regionais, enquanto iniciativas da sociedade civil, sem vinculação às Instituições de Igrejas ou grupos privados. Ocorre que a experiência como universidade comunitária ainda é relativamente nova, estando-se ainda na busca por definição e caracterização, pois se trata de um termo muito aberto partindo da ideia de comunidade, sendo algo novo que está em construção, num espaço de ampliação da esfera pública, porém ainda pouco conhecido da sociedade brasileira (FRANTZ, 2004).

Segundo Follmann (2009, p. 114):

a Constituição Federal de 1988 é clara em seu artigo 213, quando afirma como dever do estado, o repasse de recursos para as instituições de ensino comunitárias, confessionais e filantrópicas 
que prestam o seu serviço à sociedade sem fins lucrativos.

Mas, na história recente, as instituições privadas são consideradas todas iguais, com base da leitura da lei maior, sendo consideradas junto com as empresas de fins lucrativos atuantes na área do ensino.

Porém, apesar do termo "comunitária" na Constituição Federal, reconhecendo a existência destas universidades, não lhes foi permitido o livre acesso de concorrência para serem beneficiárias de recursos federais, nos mesmos moldes de instituições estatais, fazendo com que a luta destas instituições continuasse, tendo em vista que precisam subsidiar todas as suas atividades de extensão e pesquisa com recursos oriundos de mensalidades.

Follmann (2009 p. 114), afirma que:

[...] para fazer justiça aos esforços históricos e aos esforços presentes, são necessárias medidas urgentes que reconheçam, de direito e de fato a natureza comunitária e pública não estatal, dessas instituições, como já sinalizava, com pertinência, o debate em meados da década de 1980.

Um segundo momento do debate aconteceu na década de 1990 e teve sentido contrário ao anterior. A Lei de Diretrizes e Bases da Educação (LDB), promulgada em 1996 conforme a Lei nº 9.394/1996, teve uma redação prejudicial às comunitárias, pois as considerava como uma modalidade das instituições privadas (SCHIMDT, 2010). O art. 19, da LDB, estabelece apenas duas categorias de instituições de ensino: públicas e privadas, na linha da clássica dicotomia público/privado:

I - Públicas - assim entendidas as criadas ou incorporadas, mantidas e administradas pelo Poder Público;

II - Privadas - assim entendidas as mantidas e administradas por pessoas físicas ou jurídicas de direito privado.

No art. 20, a LDB explicita as modalidades de instituições privadas:

I - Particulares em sentido estrito, entendidas as que são instituídas e mantidas por uma ou mais 
pessoas físicas ou jurídicas de direito privado que não apresentem as características dos incisos abaixo;

II - Comunitárias, entendidas as que são instituídas por grupos de pessoas físicas ou por uma ou mais pessoas jurídicas, inclusive cooperativas de pais, professores e alunos, que incluam em sua entidade mantenedora representantes da comunidade;

III - Confessionais, entendidas as que são instituídas por grupos de pessoas físicas ou por uma ou mais pessoas jurídicas que atendem a orientação confessional e ideologia específicas e ao disposto no inciso anterior;

IV - Filantrópicas na forma da lei.

De acordo com Frantz (2004, p. 10) o artigo 20,

Reconhece e define esse marco jurídico da sociedade brasileira diferentes níveis e categorias de instituições de ensino superior: universidades públicas estatais e universidades privadas, sendo estas particulares em sentido estrito, confessionais, comunitárias e filantrópicas, conforme os Artigos 19 e 20 da Lei no 9.394.

Segundo o artigo $3^{\circ}$ do Decreto $\mathrm{n}^{\circ}$ 2.306/1997, as entidades mantenedoras de instituições privadas de ensino superior, comunitárias, confessionais e filantrópicas ou constituídas como fundações, não poderão ter finalidade lucrativa. E conforme o artigo $2^{\circ}$ do mesmo Decreto, as entidades mantenedoras de instituições de ensino superior, sem finalidade lucrativa, deverão:

$>$ Ser certificadas por auditores independentes, com o parecer do conselho fiscal, ou órgão similar;

$>\quad$ Manter escrituração completa e regular de todos os livros fiscais, na forma da legislação pertinente, bem como de quaisquer outros atos ou operações que venham a modificar sua situação patrimonial, em livros revestidos de formalidades que assegurem a respectiva exatidão; 
$>$ Conservar em boa ordem, pelo prazo de cinco anos, contados da data de emissão, os documentos que comprovem a origem de suas receitas e a efetivação de suas despesas, bem como a realização de quaisquer outros atos ou operações que venham a modificar sua situação patrimonial;

$>\quad$ Submeter-se, a qualquer tempo, à auditoria pelo Poder Público;

$>\quad$ Destinar seu patrimônio a outra instituição congênere ou ao Poder Público, no caso de encerramento de suas atividades, promovendo, se necessário, a alteração estatutária correspondente;

$>$ Comprovar, sempre que solicitada:

a) a aplicação dos seus excedentes financeiros para os fins da instituição de ensino superior mantida;

b) a não-remuneração ou concessão de vantagens ou benefícios, por qualquer forma ou título, a seus instituidores, dirigentes, sócios, conselheiros ou equivalentes;

c) a destinação, para as despesas com pessoal docente e técnico-administrativo, incluídos os encargos e benefícios sociais, de pelo menos $60 \%$ (sessenta por cento) da receita das mensalidades escolares provenientes da instituição de ensino superior mantida, deduzidas as reduções, os descontos ou bolsas de estudo concedidas e excetuando-se, ainda, os gastos com pessoal, encargos e benefícios sociais dos hospitais universitários.

Com as características exigidas no Decreto $n^{\circ}$ 2.306/1997, das instituições não possuírem finalidade lucrativa e precisarem aplicar o excedente dos recursos disponíveis na área da educação e em suas atividades acadêmicas, estarem voltadas aos serviços da comunidade, são características inerentes às universidades comunitárias, pois elas não buscam a remuneração pelo capital investido. Segundo Franz (2004 p. 10) "tanto a Constituição de 1988, como a Lei de Diretrizes e Bases da Educação Nacional de 1996 e o Decreto No 2.306, de 19 de agosto de 1997, consagram o conceito e as responsabilidades das universidades comunitárias, no contexto do ensino superior brasileiro".

O Consórcio das Universidades Comunitárias Gaúchas (COMUNG) elaborou um documento que caracteriza e define as 
universidades comunitárias. O documento entende as comunitárias como públicas não estatais, permitindo apontar diferenças fundamentais com as outras categorias de organizações do ensino superior e Frantz (2004, p. 11) escreve que "no texto do referido documento, podem-se verificar os argumentos e as razões que fundamentam, sob o ponto de vista das próprias universidades, portanto, uma auto definição, a sua natureza pública não estatal e comunitária”.

De acordo com o documento:

a) As universidades acima identificadas são instituições públicas não-estatais, surgidas de iniciativas essencialmente comunitárias, e definidas como não confessionais, nãoempresariais, e sem alinhamento políticopartidário ou ideológico de qualquer natureza.

b) Desenvolvem um serviço educativo e científico sem fins lucrativos sendo todos os seus excedentes financeiros reaplicados em educação, só em território nacional.

c) $\mathrm{O}$ patrimônio dessas instituições não pertence a um dono, grupo privado ou confissão religiosa, mas a fundações comunitárias, cuja totalidade dos bens tem, conforme o explicitado em seus estatutos, destinação pública, revertendo, em caso de dissolução para o controle do Estado. Os dirigentes dessas fundações não são remunerados no exercício de sua função. Seus balanços são de domínio público - após análise e aprovação internas, são submetidos a auditores independentes, a um conselho de curadores e à aprovação do Ministério Público.

d) No que se refere à gestão, caracterizam-se pela eleição democrática de seus dirigentes, de que participam todos os segmentos da comunidade acadêmica e representantes da comunidade regional. Ressalta-se que de seus conselhos superiores, participam também representantes da comunidade externa.

e) As atividades de ensino, pesquisa e extensão, desenvolvidas por essas 
instituições, têm uma vinculação privilegiada com a comunidade regional, destacando-se projetos ligados à promoção humana e social de segmentos excluídos ou de camadas da população de menor poder aquisitivo: menores, idosos, deficientes, analfabetos, moradores de periferia, pequenos agricultores, indígenas, doentes, presidiários etc.

f) Sua localização geográfica e vinculação social permitem o acesso ao ensino superior dos alunos que, a princípio, tem dificuldade de ingressar nas universidades públicasestatais. Nesse sentido, as públicas nãoestatais são a única possibilidade de democratização do ensino superior em sua região de abrangência, não apenas pela proximidade geográfica de seus alunos, mas também por praticarem custos de manutenção compatíveis com a realidade regional.

g) Estas instituições, valendo-se dos incentivos fiscais derivados da filantropia, implantaram, de forma criativa, mecanismos para a manutenção de alunos oriundos de classes menos privilegiadas, instalando programas de bolsas, fundos de apoio e, especialmente políticas de mensalidades acessíveis às possibilidades econômicas das famílias da região. (COMUNG, 1998 apud FRANTZ, 2004, p. 11-12).

As universidades comunitárias podem ser entendidas como a ampliação dos espaços do setor público por meio da mobilização cultural e política da população, que se sente excluída pelas políticas públicas, onde os deveres e direitos da educação devem ser discutidos. Podendo ter como função, a de preencher a ausência da ação do Estado, fazendo o papel do Estado e governo, a característica essencial das universidades comunitárias (FRANTZ, 2004).

O terceiro momento de debate das instituições comunitárias ocorreu no processo de Reforma Universitária iniciado em 2004, o qual fez com que as universidades comunitárias viessem a reivindicar a substituição da díade público/privado pela tríade público/comunitário/privado, e no projeto de Reforma Universitária 
enviado pelo Congresso que estabelece no art. $8^{\circ}$ três categorias de instituições de ensino superior: públicas, comunitárias e particulares (SCHMIDT, 2010).

Assim, na primeira década do século XXI, com o processo de discussão da reforma Universitária desencadeado em 2004, as universidades comunitárias pedem a substituição da díade público/privado pela tríade público/comunitário/privado e obtiveram êxito parcial. O projeto encaminhado estabelece três categorias de instituições de ensino superior: públicas, comunitárias e particulares, instituindo conforme o art. 20 da Lei $\mathrm{n}^{\circ} 9.394$ explicita, as modalidades de instituições privadas: I - particulares, II - comunitárias, III confessionais e IV - filantrópicas (SCHMIDT 2010).

De acordo com Schimdt (2010, p. 32),

$\mathrm{O}$ anteprojeto apresentado pelos juristas considerou "altamente relevante" incluir no instrumento que trata da organização da administração pública o tratamento a ser dado aos entes de colaboração, entidades que "embora instituídas no âmbito não estatal - ainda que, em alguns casos, com impulso estatal - desenvolvem atividades de interesse público, que as habilitam a atuar como parceiras do Estado. Elas estão a meio caminho entre o estatal e o não estatal, gerindo, muitas delas, verbas públicas". Os entes de colaboração indicados no documento são as organizações não governamentais, mas a lógica dos juristas é plenamente compatível com os pressupostos de um marco legal das comunitárias.

A seguir, será apresentado o histórico de formação e as características das universidades catarinenses, as quais tiveram sua origem, por meio das fundações educacionais criadas pelo poder público municipal no final da década de 1950 e início da década 1960.

\subsubsection{As universidades comunitárias Catarinenses}

No final da década de 1950, o estado de Santa Catarina não possuía universidades, assim, a maioria dos jovens que pretendiam cursar o ensino superior, deslocavam-se para os estados vizinhos, para o Rio de Janeiro e São Paulo. Naquele período, em Florianópolis, existia a oferta de alguns cursos superiores, sendo os cursos de direito, ciências 
econômicas, odontologia, medicina, farmácia, filosofia, serviço social e engenharia industrial. Estes cursos eram lecionados em faculdades isoladas, os quais, mais tarde se constituíram na Universidade Federal de Santa Catarina (UFSC), criada em 1960 (LIMA, 2009).

Em Santa Catarina as universidades comunitárias começaram a ser constituídas, a partir do final da década de 1950, tendo como objetivo, a interiorização do ensino superior. Suas atividades tiveram início via fundações educacionais criadas pelos municípios, pois nesse período, o ensino superior era ofertado apenas na capital do estado ou nos estados vizinhos (Paraná e Rio Grande do Sul). No estado de Santa Catarina, o estoque de capital social foi um dos fatores fundamentais do suprimento e fortalecimento das universidades comunitárias. Sendo peculiar no modelo comunitário catarinense, a presença do poder público local, em especial das prefeituras municipais (SCHMIDT, 2010).

De acordo com Gumbowaky (2014, p. 93), a Lei Federal $\mathrm{n}^{\circ}$ 4.024/61, em seu artigo 107, concedeu estímulo às fundações educacionais ao mencionar que:

O poder público estimulará a colaboração popular em favor das fundações e instituições culturais e educativas de qualquer espécie, grau ou nível sem finalidades lucrativas, e facultará aos contribuintes do imposto de renda a redução dos auxílios ou doações comprovadamente feitas a tais entidades.

A Lei Federal $\mathrm{n}^{\circ}$ 5.540/68, no seu artigo $2^{\circ}$, dispõe que "o ensino superior indissociável da pesquisa será ministrado em universidades e, excepcionalmente, em estabelecimentos isolados, organizados como instituições de direito público ou privado".

Apesar das Leis Federais $n^{\circ}$. 4.024/61 e $n^{\circ}$. 5.540/68 estabelecerem na reforma universitária que o ensino superior deveria ser ministrado em universidades, no contexto catarinense, prevaleceu o crescimento das instituições isoladas de ensino superior. Então frente a esse contexto, começou-se a delinear as primeiras iniciativas com vistas à criação de instituições de ensino superior isoladas em Santa Catarina, sendo uma das primeiras a Fundação das Escolas Unidas do Planalto Catarinense, atual Universidade do Planalto Catarinense (UNIPLAC) (GUMBOWAKY, 2014). 
Segundo Gumbowaky (2014), esse processo teve seu início com mais ênfase em 1964, desencadeando iniciativas irreversíveis de:

a) interiorização da oferta de ensino superior;

b) democratização das oportunidades de acesso a cursos superiores de formação profissional;

c) formação de quadros vocacionados para o atendimento das necessidades locais;

d) constituição de um corpo de professores capacitados, selecionados segundo os critérios exigidos pelo Conselho Federal de Educação;

e) instalação de uma infraestrutura de ensino qualificada; $\mathrm{e}$,

f) disseminação, por todo o estado, de equipamentos laboratoriais e de bibliotecas especializadas.

Diversos municípios do estado criaram suas fundações educacionais de ensino superior, e o seu patrimônio na maioria das vezes, se resumia a uma área de terra para a futura construção de instalações. Para Lima (2009, p. 93),

Apesar de certo centralismo conservador, presente em boa parcela dos governantes e das pessoas ligadas ao ensino, aos poucos as comunidades regionais e microrregionais começaram a se organizar, dando vida a um sistema fundacional de educação superior totalmente diferenciado de qualquer outra experiência vivida nos demais estados da federação brasileira.

Com o avanço das fundações, em 1974, nasceu a Associação Catarinense das Fundações Educacionais (ACAFE), pensada como entidade capaz de congregar e integrar as fundações educacionais na busca do fortalecimento, ordenação, das articulações e do planejamento de um sistema de ensino superior regionalizado. A sede da ACAFE fica em Florianópolis e atualmente congrega dezesseis instituições de ensino, as quais estão distribuídas por todo o estado de Santa Catarina (LIMA, 2009).

Entre as instituições vinculadas a ACAFE estão as que foram criadas pelas fundações educacionais e que tiveram origem, a partir dos poderes públicos municipais, a UDESC criada pelo governo do estado de Santa Catarina e um Centro Universitário Municipal público e 
gratuito. Destaca-se que o Centro Universitário é o primeiro do País a ser público e gratuito.

No quadro 01, apresenta-se a relação das Instituições vinculadas à ACAFE, com o seu respectivo ano de criação.

Quadro 01 - Instituições de Ensino da ACAFE

\begin{tabular}{|c|c|c|}
\hline & Fundação / Universidade & $\begin{array}{l}\text { Ano de } \\
\text { criação das } \\
\text { Fundações } \\
\end{array}$ \\
\hline 1 & \begin{tabular}{lccr} 
Fundação das & \multicolumn{2}{c}{ Escolas Unidas } & do Planalto \\
Catarinense & - & Fundação & UNIPLAC \\
Universidade & do & Planalto & Catarinense \\
(UNIPLAC) & & &
\end{tabular} & 1959 \\
\hline 2 & $\begin{array}{l}\text { Fundação UNIVALI } \\
\text { Universidade do Vale do Itajaí (UNIVALI) }\end{array}$ & 1962 \\
\hline 3 & $\begin{array}{l}\text { Fundação Universidade Regional de } \\
\text { Blumenau } \\
\text { Universidade Regional de Blumenau (FURB) }\end{array}$ & 1964 \\
\hline 4 & $\begin{array}{l}\text { Fundação Universidade do Estado de Santa } \\
\text { Catarina } \\
\text { Universidade do Estado de Santa Catarina } \\
\text { (UDESC) }\end{array}$ & 1964 \\
\hline 5 & $\begin{array}{l}\text { Fundação Universidade do Sul de Santa } \\
\text { Catarina } \\
\begin{array}{l}\text { Universidade do Sul de Santa Catarina } \\
\text { (UNISUL) }\end{array}\end{array}$ & 1965 \\
\hline 6 & $\begin{array}{l}\text { Fundação Educacional do Alto Vale do Itajaí } \\
\text { (FEDAVI) /Centro Universitário para o } \\
\text { Desenvolvimento do Alto Vale do Itajaí } \\
\text { (UNIDAVI) }\end{array}$ & 1966 \\
\hline 7 & $\begin{array}{l}\text { Fundação Educacional da Região de Joinville } \\
\text { (FURJ) } \\
\begin{array}{l}\text { Universidade da } \\
\text { (UNIVILLE) }\end{array}\end{array}$ & 1967 \\
\hline 8 & $\begin{array}{l}\text { Fundação Universidade do Oeste de Santa } \\
\text { Catarina (FUNOESC) Universidade do Oeste } \\
\text { de Santa Catarina (UNOESC) }\end{array}$ & 1968 \\
\hline 9 & $\begin{array}{l}\text { Fundação Educacional de Criciúma (FUCRI) } \\
\text { Universidade do Extremo Sul Catarinense } \\
\text { (UNESC) }\end{array}$ & 1968 \\
\hline
\end{tabular}


Quadro 01 - Instituições de Ensino da ACAFE

(Conclusão)

\begin{tabular}{|c|c|c|}
\hline & Fundação / Universidade & $\begin{array}{l}\text { Ano de } \\
\text { criação das } \\
\text { Fundações }\end{array}$ \\
\hline 10 & $\begin{array}{l}\begin{array}{l}\text { Fundação Universidade do Contestado } \\
\text { (FUnC) } \\
\text { Universidade do Contestado (UNC) }\end{array} \\
\end{array}$ & 1970 \\
\hline 11 & $\begin{array}{l}\text { Fundação de Ensino do Desenvolvimento do } \\
\text { Oeste (FUNDESTE) } \\
\text { Universidade Comunitária Regional de } \\
\text { Chapecó (UNOCHAPECÓ) }\end{array}$ & 1972 \\
\hline 12 & $\begin{array}{l}\text { Fundação Educacional do Alto Vale do Rio do } \\
\text { Peixe (FEARPE) Universidade Alto Vale do } \\
\text { Rio do Peixe (UNIARP) }\end{array}$ & 1971 \\
\hline 13 & $\begin{array}{l}\text { Fundação Educacional de } \text { Brusque (FEBE) } \\
\text { Centro Universitário de } \\
\text { (UNIFEBE) }\end{array}$ & 1973 \\
\hline 14 & $\begin{array}{l}\text { Centro Universitário Catarinense de Santa } \\
\text { Catarina }\end{array}$ & 1973 \\
\hline 15 & $\begin{array}{lll}\text { Fundação Educacional } & \text { Barriga } & \text { Verde } \\
\text { (FEBAVE) } & & \\
\text { Centro Universitário } & \text { Barriga } & \text { Verde } \\
\text { (UNIBAVE) } & & \end{array}$ & 1974 \\
\hline 16 & $\begin{array}{l}\text { Fundação Educacional de São José } \\
\text { (FUNDESJ) } \\
\text { Centro Universitário Municipal de São José } \\
\text { (USJ) }\end{array}$ & 2005 \\
\hline
\end{tabular}

Fonte: ACAFE (2017).

Com relação à direção das universidades, o controle administrativo e financeiro é realizado pela mantenedora que são as fundações criadas pelo poder público municipal, consideradas instituições de direito privado, de associação ou sociedade civil, e os seus dirigentes são eleitos pela comunidade acadêmica etou por representantes da comunidade regional, e, a direção eleita é constituída por docentes da universidade (SCHMIDT, 2010).

As fundações educacionais existentes no estado e, por consequência, as universidades delas originadas, têm como mola propulsora e como base de atuação o envolvimento com sua região e a intenção/missão de agente de desenvolvimento regional. As 
universidades com o passar dos tempos vêm sendo parceiras constantes das comunidades de suas regiões, em todo o processo de melhoria da qualidade de vida e de desenvolvimento, em todos os âmbitos das realidades microrregionais, seja no setor econômico propriamente dito, seja na ambiência humana e social (LIMA, 2009).

Com base em Lima (2009) pontua-se que é necessário destacar algumas atitudes e atividades que podem ser decisivas no momento presente e no futuro da vida e atuação das instituições de ensino associadas à ACAFE:

$\checkmark$ Utilização com efetividade dos laboratórios existentes para prestar serviços de qualidade à comunidade empresarial da região do estado e do Brasil. Aprender a vender os serviços que pode prodigalizar. Ter os poderes públicos também como parceiros a quem vender esses serviços, com ênfase especial na área ambiental;

$\checkmark$ É sumamente necessário dar visibilidade ao que precisa ser visto, o marketing institucional é primordial;

$\checkmark$ Manter um banco de dados dinamicamente atualizado para possibilitar as instituições esse bom falar de si;

$\checkmark$ Efetuar um estudo acurado de viabilidade para implantar qualquer curso. Esta decisão não pode se atribuir simplesmente na vontade discricionária de alguém ou de alguns poucos. Nem na beleza do projeto.

$\checkmark$ Afastar-se da prática de amontoar tijolos sobre tijolos, construindo imobilizados que podem fazer sucumbir no meio onde interagem, devido às diversas dificuldades econômicas e sociais do sistema. Investir e investir nas pessoas, chamando-as a exercer suas lideranças e assim, ter delas, o seu melhor em termos de dedicação, trabalho e fidelização;

$\checkmark$ Desenvolver o processo de internacionalização como uma das estratégias básicas de gestão universitária;

$\checkmark$ Dar ênfase aos programas institucionais de Iniciação Cientifica que podem ser a base de uma futura e decisiva ação na pesquisa; 
$\checkmark$ Buscar incessantemente a integração inter pares. Abrir canais de uma comunicação verdadeira, às claras, sem peias nem meias verdades. Participar de projetos conjuntos com as associadas nas áreas de ensino, da pesquisa e da prestação de serviços.

Talvez, prepararem-se todas as instituições da ACAFE para num futuro não muito distante, se transformarem numa grande e única universidade, presente em todo o estado e, capaz de atuar plenamente como o grande pilar do ensino superior, tendo a indissociabilidade entre a investigação, intervenção, extensão e ensino (LIMA, 2009).

Atualmente, as instituições vinculadas ao sistema ACAFE já buscam estratégias comuns para soluções das demandas administrativas que surgem nas ICES distribuídas no estado. Reúnem-se com frequência na busca de compartilhamento dos problemas comuns nas áreas jurídicas, marketing, desenvolvimento, tecnologia da informação e gestão administrativa financeira, por meio de câmeras de discussão e busca de soluções coletivas.

\subsubsection{Reconhecimento como universidade comunitária}

O discurso das instituições comunitárias gaúchas e catarinenses quanto à sua origem e identidade é pública e não-estatal, são fatos reafirmados de maneira insistente nos documentos das universidades e pelas entidades representativas. Para algumas vertentes de instituições comunitárias este discurso é apenas um acessório, porém, nas comunitárias regionais é o elemento central, estando este caráter comunitário expresso nas diversas formas de relação das universidades com a sociedade civil e o poder público, como exemplo, na participação de integrantes da comunidade regional nas decisões da universidade e na gestão democrática das instituições (SCHMIDT, 2010).

Assim, a luta constante das associações das universidades, para serem reconhecidas pelo seu trabalho e sua condição especial, quanto a sua natureza jurídica, foi intensa e vêm ao longo de sua história de formação. Resulta que nas últimas décadas, surgiram diferentes iniciativas, apoiadas no marco jurídico constitucional e legal, com a função de promover a educação universitária.

Em 2008, as entidades representativas das universidades comunitárias gaúchas e catarinenses, o COMUNG e a ACAFE, tomaram a iniciativa de formular e propor ao Governo Federal e ao Congresso 
Nacional um projeto de lei das instituições comunitárias. Com isso, a Associação Brasileira das Universidades Comunitárias (ABRUC), em 2009, e outras entidades representativas das universidades comunitárias brasileiras, incluindo a Associação Nacional de Educação Católica do Brasil (ANEC) e a Associação Brasileira de Instituições Educacionais Evangélicas (ABIEE), tiveram seus discursos unificados em uma ação, em favor do marco legal pelo qual o Estado e a sociedade passassem a reconhecê-las, como instituições com características distintas das privadas (SCHMIDT, 2010).

Em 2009, as entidades representativas das instituições comunitárias de ensino superior, fizeram um manifesto conjunto direcionado às autoridades brasileiras, especialmente aos parlamentares, que integravam a Frente Parlamentar Mista de Defesa das Universidades Comunitárias, para manifestar sua posição em favor da formulação de um Marco Legal das Instituições Comunitárias. A partir deste documento, ocorreram movimentações no Congresso Nacional, com o apoio de diversos parlamentares, e então, foi construída a proposta de Lei. O dia 13 de julho de 2010, é a data oficial do protocolo oficial na Câmara dos Deputados do projeto de Lei das Instituições Comunitárias PL $n^{\circ}$ 7639/2010, que passou a ser conhecido PL DAS COMUNITÁRIAS.

Após passar pelas diversas comissões, o referido Projeto de Lei foi aprovado na Câmara dos Deputados, em 2012. Em todas as comissões obteve apoio unânime, ficando evidenciado que se tratava de um assunto de interesse de toda a sociedade. Em seguida o Projeto foi encaminhado ao Senado com a expectativa de conclusão dos tramites em 2013 (PLC 01/2013 APROVADO NO SENADO). Finalmente, em outubro de 2013, o Projeto de Lei das Comunitárias foi aprovado no Senado Nacional.

Ocorreram duas audiências na casa civil, em 30 de outubro e 12 de novembro de 2013, e a Lei das Comunitárias foi publicada em edição extra do Diário Oficial da União, no dia 12 de novembro de 2013, conforme notícia publicada na página da ABRUC.

O Diário Oficial da União, na edição (extra) $\mathrm{n}^{\circ}$ 221-A, de 12 de novembro de 2013, publica a Lei 12.881, a Lei das Instituições Comunitárias de Educação Superior. Assinada pela Presidenta Dilma Roussef e os ministros Guido Mantega, Aloisio Mercadante, Miriam Belchior e Luis Inácio Adams. Com três vetos pontuais (inciso $3^{\circ}$ 
do art. $2^{\mathrm{o}}$ e art. 11 e 13), a lei aprovada corresponde em mais de $95 \%$ ao texto formulado pelas entidades representativas das instituições comunitárias.

Segundo noticiado pela ABRUC,

É, pois, uma autêntica lei elaborada pela sociedade civil e avalizada pelo Estado, através do Congresso Nacional e do Executivo. Uma lei que inaugura uma nova era para as universidades comunitárias na sua relação com o Estado brasileiro, que abre as portas para um processo de cooperação marcado pela complementaridade e sinergia.

A lei $\mathrm{n}^{\mathrm{o}}$ 12.881, de 12 de novembro de 2013, dispõe sobre a definição, qualificação, prerrogativas e finalidades das ICES, disciplina o Termo de Parceria e dá outras providências. Com a aprovação da Lei das Comunitárias, as instituições, a outorga da qualificação de Instituição Comunitária de Educação Superior é ato vinculado ao cumprimento dos requisitos instituídos por esta Lei. Conforme o artigo $2^{\circ}$ da lei as Instituições Comunitárias de Educação Superior contam com as seguintes prerrogativas:

I - ter acesso aos editais de órgãos governamentais de fomento direcionados às instituições públicas; e

II - receber recursos orçamentários do poder público para o desenvolvimento de atividades de interesse público;

Com o reconhecimento como universidades comunitárias, por meio da lei $\mathrm{n}^{\circ} 12.881$, as instituições passaram a ter novas perspectivas de sustentabilidade econômica e financeira, para poderem continuar suas atividades, e assim conseguir cumprir o papel de relevante importância para o desenvolvimento regional, pois com o devido reconhecimento, passam a ter condições de acesso aos editais públicos de fomentos à pesquisa e extensão que até então, eram exclusividade das Universidades Públicas.

Assim, as ações encaminhadas pelas universidades comunitárias, fizeram com que fossem reconhecidas de maneira diferenciada, pela sua 
especificidade e características próprias, como àquela criada e mantida pela sociedade civil e contribuindo para o desenvolvimento do país, por meio da oferta de uma educação de boa qualidade. As universitárias comunitárias têm vocação pública: estão voltadas para o desenvolvimento das comunidades, e não, para o interesse pessoal ou particular (VENANZI; SANDANO, 2014).

\subsection{AÇÕES DAS INSTITUIÇÕES COMUNITÁRIAS DE ENSINO SUPERIOR QUE PROMOVEM O DESENVOLVIMENTO SOCIOECONÔMICO REGIONAL}

Nesta seção, por intermédio de publicações existentes, pretendese demonstrar evidências das ações que as IES realizam, de maneira a contribuir para o desenvolvimento regional, entendendo as Instituições de Ensino Superior como agentes propulsores do desenvolvimento regional, pois suas ações vão além de formar mão de obra especializada, já que as universidades possuem um papel maior do que apenas a formação.

\subsubsection{Desenvolvimento Regional}

A relação existente entre educação e desenvolvimento, já era evidenciada pela literatura econômica, a qual demonstra que a educação é fator relevante para o crescimento e desenvolvimento de uma nação. Suas evidências têm origem em Adam Smith no livro "A riqueza das nações", publicado em 1776, no qual consta que a acumulação de conhecimento era o instrumento que propiciava o aumento de produtividade ao trabalhador, e este conhecimento foi denominado de capital social (ROLIM; SERRA, 2013).

As instituições de ensino superior estão inseridas nos contextos do desenvolvimento das regiões como agentes fundamentais do processo, devido a serem agentes geradores de novos conhecimentos e da formação de capital humano. Por intermédio das funções principais das universidades, formação educacional e pesquisa, as quais estão atreladas as suas demais funções secundárias, é que as IES assumem o papel de agentes dinamizadores no processo de desenvolvimento regional (SIRQUEIRA; FERRAZ, 2014).

De acordo com Fleck (2011, p. 274), 
contínuas, intensamente complexo, que envolve transformações não somente de ordem econômica como transformações de ordem política e, fundamentalmente, de ordem humana e social.

As universidades promovem diversas interações com a comunidade, o que ocasiona efeitos que contribuem para o desenvolvimento regional. Esses efeitos se fazem sentir por intermédio da geração de capital humano por meio do ensino, da difusão do conhecimento por meio da pesquisa, da prestação de serviços realizados à sociedade e por meio da extensão (BOVO, 2003).

Sirqueira e Ferraz (2014, p. 3), também esclarecem que,

Os efeitos de uma universidade vão muito além dos tradicionais impactos na criação do capital humano e do conhecimento. Decorre também de sua influência fatores outros, tais como, o volume de investimentos em capital físico, em construção e manutenção de edifícios, laboratórios nas regiões onde estão inseridas.

Quando se buscam respostas para a competitividade de uma região, um dos fatores que surge de maneira consensual nos diversos estudos, é a importância que possui o capital humano, na contribuição para o desenvolvimento socioeconômico da região, por possuir diferenciais competitivos. A sociedade vive em um meio caracterizado por cobranças e pressões externas para que ocorram práticas sociais que demonstrem a responsabilidade social das empresas. E neste meio, estão as Instituições de Ensino Superior (IES), focadas na educação, e são vistas como formadoras de competências, possuindo o papel de formar seus acadêmicos para aspectos tanto sociais quanto econômicos (REIS; BANDOS, 2012).

Em função das transformações ocorridas, as universidades vêm ganhando mais importância, constituindo-se em agentes de promoção do desenvolvimento, além de ofertarem conhecimento nas diversas áreas, formando profissionais que possam atuar no mercado de trabalho, possibilitando à população, o acesso às inovações científicas (SIRQUEIRA; FERRAZ, 2014).

Reis e Bandos (2012, p. 424) entendem que,

[...] cabe às universidades trazerem ao conhecimento dos seus alunos os problemas da 
sociedade em geral, e de forma particular da sua região ou cidade, para que através destes possam ser criadas soluções viáveis, inovações e a responsabilidade com a sociedade de forma geral.

Nos últimos anos, as universidades vêm recebendo crescente atenção, no que diz respeito a serem agentes do desenvolvimento regional, sendo consideradas como elemento chave no processo. E com a compreensão, nas últimas décadas, de que as inovações têm papel relevante no processo de desenvolvimento econômico, houve uma preocupação crescente com os condicionantes dessas inovações (ROLIM; SERRA, 2009b).

Assim, no atual contexto social, de envolvimento das instituições de ensino com o desenvolvimento regional, o professor não pode mais se preocupar apenas com teorias. Precisa contribuir com práticas sociais, preocupando-se em oferecer ao mercado, ou ao mundo, um profissional com melhor preparação, com capacidade de solucionar problemas sociais (REIS; BANDOS, 2012).

Para que as Instituições de Ensino Superior possam contribuir com o desenvolvimento regional, não podem ficar apenas na questão do educar. Devem engajar-se na busca deste objetivo de crescimento e de melhorias socioeconômicas da região, fortalecendo os pilares que as identificam como fontes geradoras de desenvolvimento, na tríade ensino-pesquisa-extensão (FLECK, 2011).

Com isto, visando refletir a Responsabilidade Social das IES sob um prisma sistêmico e tendo em vista o desenvolvimento da comunidade local, apresenta-se a seguir na figura 01, para uma melhor compreensão, um sistema e seus componentes. Visualizam-se os componentes do sistema, as entradas, suas interações, relacionamentos e saídas e o processo de feedback (REIS; BANDOS, 2012). 
Figura 01 - Abordagem sistêmica da responsabilidade social das IES.

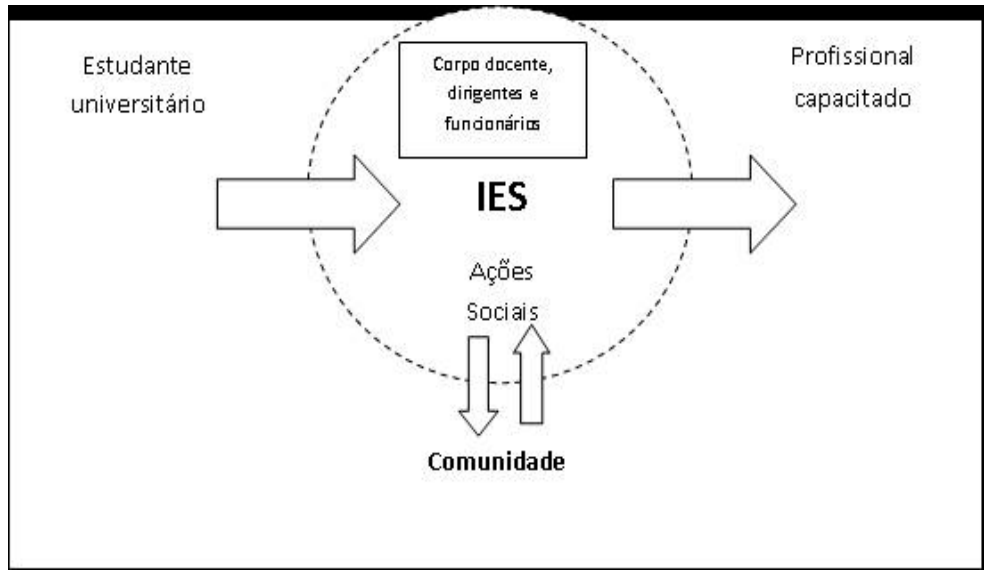

Fonte: Reis e Bandos (2012).

No sistema exposto na figura 01 , as entradas são representadas pelos estudantes que procuram uma formação profissional nas universidades, de maneira a conseguir melhor se posicionar no mercado de trabalho. É nesse processo que ocorre a interação e o relacionamento dos alunos com as faculdades. Momento em que surge o papel das Instituições de Ensino Superior, as quais sustentadas por seus pilares do ensino, pesquisa e extensão, desenvolvem em seus alunos competências de suas respectivas áreas, possibilitando o contato com desafios reais da comunidade, tornando possível o desenvolvimento das cidades onde estão localizadas (REIS; BANDOS, 2012).

A moderna concepção de desenvolvimento considera que as regiões com maior possibilidade de desenvolver-se são aquelas que conseguem estabelecer um projeto político de desenvolvimento congregando os seus diferentes atores. Faz parte desse projeto político, na sua vertente econômica, a utilização intensiva e coordenada do conjunto de conhecimentos existentes na região para aumentar a sua competitividade (ROLIM; SERRA, 2009b).

A interação dos alunos nos aspectos sociais, políticos, econômicos e culturais da comunidade local, possibilitada pela universidade, desenvolve a responsabilidade social destes e, indiretamente, a melhora das condições diversas das pessoas menos favorecidas (REIS; BANDOS, 2012). Na figura 02, verifica-se a representação de como ocorrem os impactos das ações das 
universidades, para a promoção do desenvolvimento regional onde atuam.

Figura 02 - Impactos regionais de uma universidade

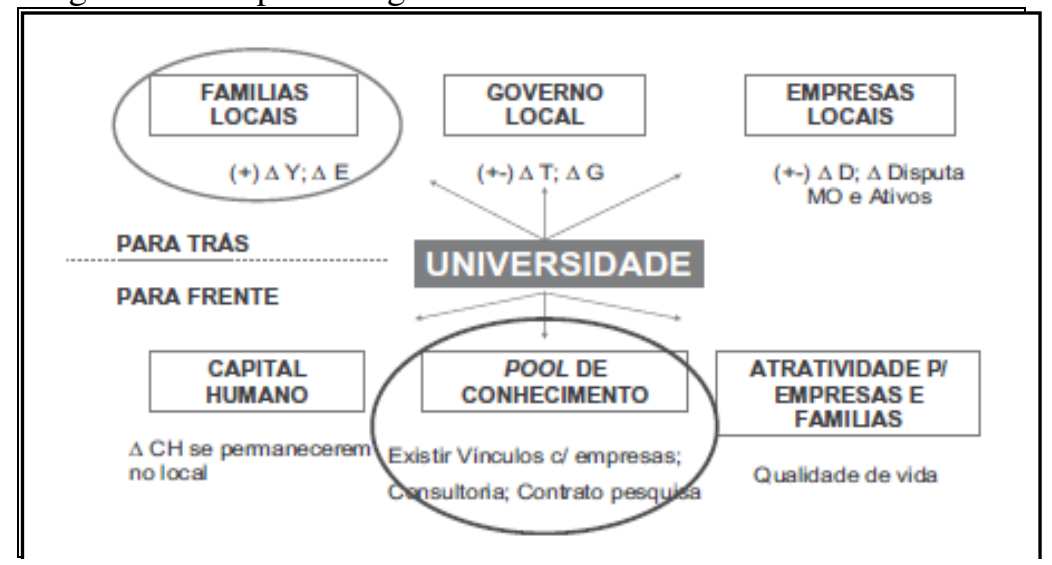

Fonte: Rolim e Serra (2009a).

A figura 02 demonstra a universidade como um agente central para o desevolvimento regional, pois, por trás das universidades existem as famílias, o governo e as empresas da região. Com as atividades das universidades, existem uma melhor capacitação das pessoas, que denomina-se capital humano, podendo existir polos de conhecimento e assim estabelecer atratividade para o estabelicimento de empresas e novas famílias.

Embora as universidades contribuam para o desenvolvimento de suas regiões, o surgimento de uma agenda de desenvolvimento regional requer a necessidade da ocorrência do engajamento regional, formalmente reconhecida como um "terceiro papel" pelas universidades. Esse "terceiro papel" vai além do que é denominado no Brasil de extensão universitária, pois as respostas para as novas demandas exigem novos tipos de recursos e novas formas de gerenciamento que permitam que as universidades façam uma contribuição dinâmica ao processo de desenvolvimento regional (ROLIM, 2009).

A interação de um sistema institucional nos territórios é caracterizada por densas redes de relacionamentos, que envolvem as universidades, as entidades de classes organizadas e o governo local, de maneira que consigam aplicar com eficiência os recursos disponíveis. Cabe às (IES) um papel fundamental para que ocorra este desenvolvimento, pois são uma das fontes de suporte para à construção 
de regiões e países desenvolvidos. Esta ação é constituída por características muito particulares do ambiente em que estão inseridas, apresentando estrutura, objetivo, e inserção comunitária distinta (FLECK, 2011).

Para que as instituições possam trabalhar como agentes propulsores do desenvolvimento, tendem a incentivar novos investimentos na região em que atuam, atraindo novos empreendimentos motivados pela atmosfera de inovação que produzem, ocasionando um impacto econômico ao seu redor, gerando novos fluxos de renda locais (ROLIM, 2009). Também contribuem com o desenvolvimento, por meio de ações que, às vezes, não são mensuradas, como organização de eventos e acesso aos acervos bibliográficos que geralmente são os mais expressivos da região. Ainda, existe a contribuição na vida cultural da região, mas nas cidades de pequeno porte estas atividades geralmente são limitadas, vinculadas às atividades culturais, como as exposições de obras de arte e o incentivo à preservação do patrimônio cultural (GUMBOWAKY, 2014).

$\mathrm{Na}$ figura 03 demonstram-se os impactos que as universidades podem gerar para o meio onde estão localizados, seu padrão acadêmico e sua capacidade de geração de conhecimento estão a serviço de soluções dos problemas regionais, posicionando a universidade como um motor propulsor do desenvolvimento regional.

Figura 03 - IES multimodais e multiescalares comprometidas regionalmente

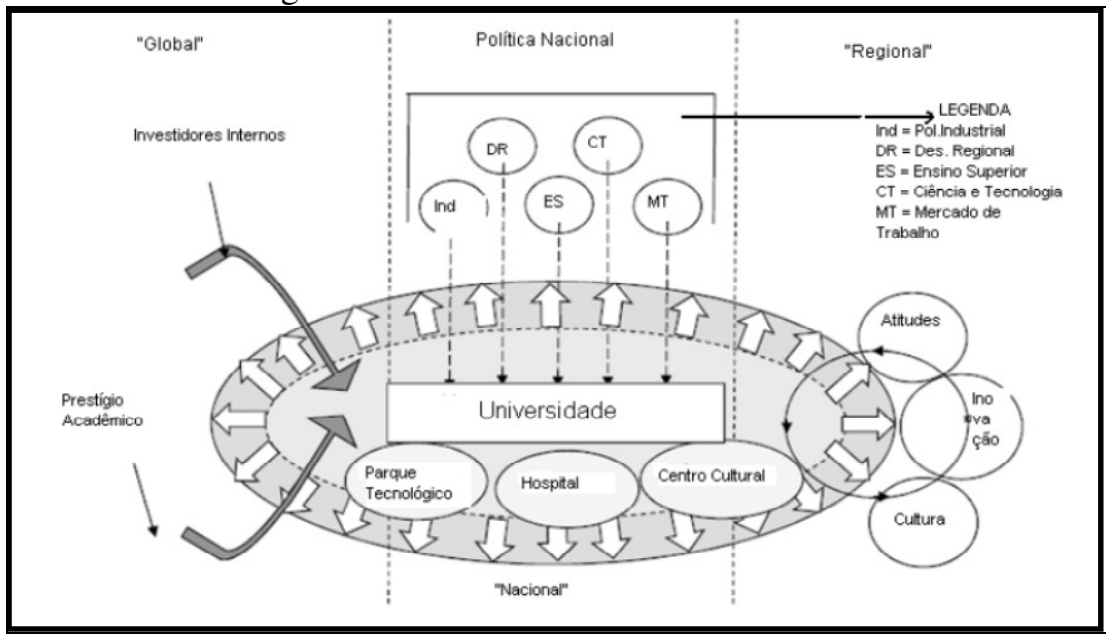

Fonte: Arbo e Benneworth (2007); Rolin (2009). 
Na figura 03 evidencia-se que por intermédio do reconhecimento, valorização acadêmica e dos investidores internos de uma região, existe a contribuição para que a presença da instituição permita que ocorram atividades vinculadas aos parques tecnológicos, hospitais e à cultura da região; como a promoção do desenvolvimento de polos industriais, do ensino superior, de centros de ciência e tecnologia e do mercado do trabalho, conseguindo dessa maneira, promover o desenvolvimento regional.

A movimentação de renda regional, ocasionada pela geração de renda, que é oportunizada pelas ações das instituições de ensino, nas cidades de pequeno e médio porte, é de grande importância socioeconômica, pois devido aos pagamentos dos salários dos funcionários e professores e demais demandas operacionais que as instituições necessitam como obras, equipamentos e despesas de manutenção, proporcionam uma grande circulação de renda local e regional, o que contribui com o desenvolvimento (GOEBEL; MIURA, 2004).

O desenvolvimento local das atividades comerciais gerado pelo aumento do consumo de alunos, docentes e funcionários, bem como o aumento dos negócios imobiliários no entorno das universidades, também pode constituir-se numa contribuição da universidade para o desenvolvimento regional ou local (GUMBOWAKY, 2014). Para Rolim (2009, p. 694), "esses trabalhos levam em conta os gastos realizados pelas universidades com o pagamento de professores e funcionários, as compras de material e toda a sorte de pagamentos realizados por elas sobre a economia da região em que estão instaladas".

Estes impactos podem ser subdivididos da seguinte maneira:

$>$ impactos sobre as famílias (acréscimos de rendas em decorrência de pagamentos diversos e dos efeitos multiplicadores decorrentes);

$>$ impacto sobre os governos locais (aumento da arrecadação, mas também maior demanda sobre bens públicos de infraestrutura); e

$>$ impacto sobre as empresas locais (aumento da demanda, mas também concorrência no mercado de compra de fatores de produção).

Pode-se concluir que para o êxito territorial, ou seja, o pleno desenvolvimento da região, é fundamental que se trabalhem questões como: quadros coletivos de ações sólidas; constituição de redes internas e externas; visão consensuada de futuro e, como resultante, densidade e 
qualidade das interações entre atores. Segundo Fleck (2011 p. 272), "para se conseguir um melhor desempenho de uma região seja em termos econômicos, sociais ou humanos, é necessário que exista um sistema institucional evoluído e complexo, para que assim consigam-se resultados positivos.".

A universidade, por meio de seu papel vinculado ao ensino, pesquisa e extensão, possui em suas mãos, elementos para promoção do desenvolvimento, e o setor produtivo demanda para as IES recursos humanos qualificados e tecnologia, que permite que o setor enfrente um ambiente de alta competitividade e globalizado. Outro fator de promoção do desenvolvimento é a geração de empreendimentos aos seus arredores, promovendo a geração de emprego e renda, o que colabora para o crescimento de desenvolvimento das cidades (GOEBEL; MIURA, 2004).

Para Fleck (2011), os vetores para o desenvolvimento regional que estão vinculados às Instituições de Ensino Superior, são:

$>\quad$ qualificação, que somente se dá a partir de um ensino de qualidade;

$>$ progresso que somente será constituído com direcionamento forte para a pesquisa; e

$>\quad$ mudança que se dá com projetos de extensão bem direcionados para o conjunto de necessidades da região e da universidade.

O modelo estruturado por Fleck (2011) sugere que por existir no país e no mundo, regiões heterogêneas tanto em termos de composição como em termos de desenvolvimento, as necessidades com relação à qualificação, progresso ou mudança tende a variar, e esse modelo somente pode se apresentar como um ciclo que se mantém em constante desenvolvimento, no qual as necessidades das regiões irão determinar qual terá maior ênfase inicial. Este modelo pode ser visualizado na figura 04: 
Figura 04 - Modelo teórico - inserção da tríade ensino pesquisa extensão no desenvolvimento regional

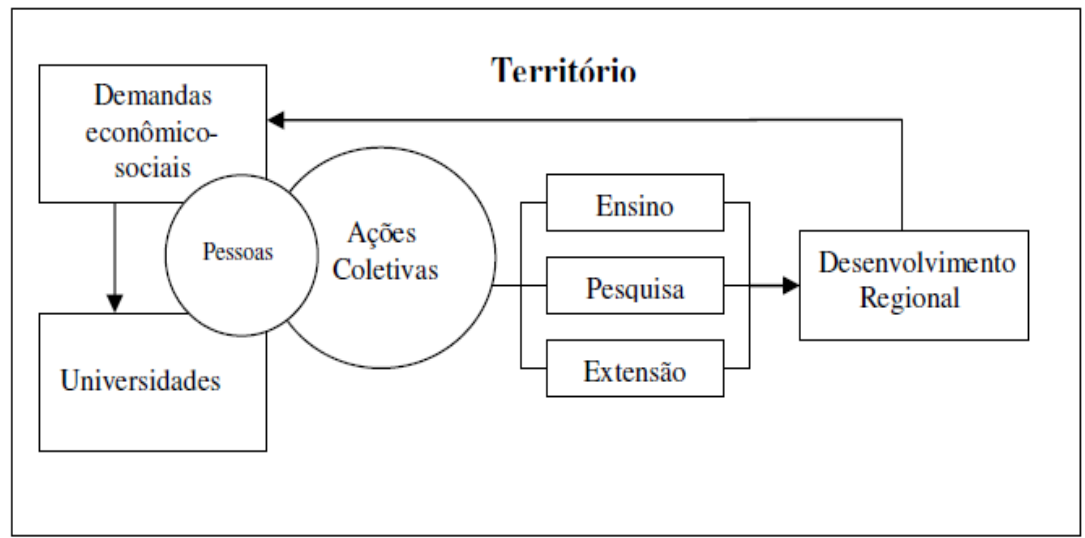

Fonte: Fleck (2011).

De acordo com o modelo proposto, a força estruturante das competências para o êxito territorial se dá a partir do indivíduo, e as universidades tornam-se instituições pela ação individual, na ação coletiva que as legitima como fonte apta a auxiliar no desenvolvimento de uma região. Essa ação individual é o ponto fundamental, portanto, os três vetores - qualificação, progresso e mudança - somente se desenvolvem com indivíduos que trabalhem por eles (FLECK, 2011).

Nesse sentido, as IES devem tornar-se interativas e vinculadas com as questões socioeconômicas da região onde estão inseridas, criando mecanismos que facilitem a relação com o meio empresarial e a sociedade. A universidade deve ser uma organização com vínculo no setor produtivo, de modo que as necessidades socioeconômicas locais e regionais façam parte dos objetivos institucionais, pois são locais próprios para o desenvolvimento e transferência de conhecimento e tecnologia gerados no meio acadêmico e nos laboratórios (GOEBEL; MIURA, 2004).

As demandas econômicas e sociais de um determinado território devem ser diagnosticadas pela universidade. E, a partir dos indivíduos pertencentes à IES e à sociedade, definem-se ações coletivas que irão nortear a tríade ensino-pesquisa-extensão, e suas prioridades para atingir o desenvolvimento regional. Os resultados obtidos com as ações coletivas, e consequentemente, com a qualificação, progresso e mudança, gerarão um novo cenário territorial, do qual emergirão novas 
demandas a serem diagnosticadas, as quais necessitarão de diferentes ações da tríade, formando um fluxo contínuo de demandas e ações de desenvolvimento (FLECK, 2011).

Neste contexto, de ambiente institucional e a partir da interação dos diversos atores sociais, reflete-se nos diferentes graus de desenvolvimento das regiões. Não se deve pensar apenas na instalação da universidade ou simplesmente a instalação de uma empresa isolada. Deve-se pensar na forma como os atores interagem, formando uma rede de cooperação, fortalecendo o surgimento de um ambiente favorável à instalação de novos negócios, de um governo eficiente e eficaz, e de uma universidade sintonizada com as questões locais (MAGALHÃES et al., 2012).

Um sistema regional de inovação pode ser caracterizado por uma região onde existem meios de ligações e comunicação interativas entre os agentes propulsores do desenvolvimento, compreendendo que este conjunto de agentes é construído por universidades, laboratórios de pesquisa básica, laboratórios de pesquisas aplicadas, agências de transferência de tecnologia, organizações regionais de governança, públicas privadas, (p. ex., associações comerciais, câmeras de comércio), organizações de treinamento vocacional, bancos, empresários dispostos a desenvolver novos produtos em parcerias de risco, pequenas e grandes empresas interagindo (ROLIM; SERRA, 2009b).

Na figura 05, demonstra-se a formação de um sistema regional de inovação, o qual é composto pelos subsistemas: aprendizado, ambiente inovador e financeiro que pode ser proporcionado com a contribuição das universidades regionais. 
Figura 05 - Universidade e região

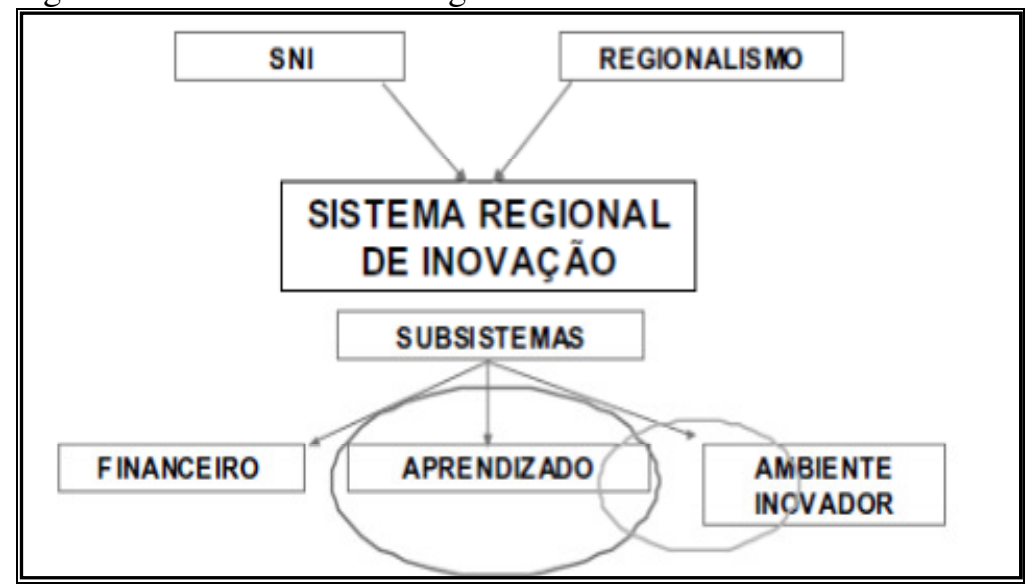

Fonte: Rolim e Serra (2009a).

Para Rolim e Serra (2009a, p. 91), "podem-se distinguir duas trajetórias claras que envolvem o papel das universidades como agentes que desempenham o desenvolvimento regional, e a distinção entre ser e estar na região faz diferença para o desenvolvimento regional."

$>\mathrm{Na}$ primeira, a universidade simplesmente se localiza na região, se caracteriza por um reduzido número de vínculos e compromissos com a região e com o seu desenvolvimento e o produto do seu trabalho está direcionado para o contexto nacional e/ou internacional. e

$>$ na segunda trajetória, a universidade demonstra ter um forte impacto no processo de desenvolvimento regional, estabelece vínculos e compromissos intensos com o futuro da região e o produto do seu trabalho, além de ter como referência a qualidade acadêmica universal, está voltado para a superação das questões da região.

Com relação à atividade do ensino, deve-se ter a preocupação da aderência das matrizes curriculares com as necessidades locais, de modo que possam estar adequadas às necessidades locais e possam contribuir com a inserção no mercado do trabalho dos formandos, e estes possam buscar constante formação por meio de cursos de pós-graduação e extensão (GUMBOWAKY, 2014).

Nesse caminho, as iniciativas individuais dos professores, como entrevistas, aconselhamento de governos, estudos tecnológicos e análises socioeconômicas são iniciativas que podem contribuir no 
atendimento das necessidades regionais. As universidades devem manter diálogos com os segmentos que são responsáveis pelo desenvolvimento regional; as autoridades eleitas locais e regionais; os empregadores e as organizações patronais; as organizações culturais; os meios de comunicação regionais; os níveis inferiores do sistema educativo; os recém-diplomados e, os estudantes atuais e futuros (GUMBOWAKY, 2014).

Os atores deste modelo (universidade-empresa-governo) protagonizam ações cívicas, educacionais e de desenvolvimento, em que a universidade tem a função de formar agentes que multipliquem as atitudes inovadoras e mudanças e o governo fomente essas ações por intermédio de criação de políticas públicas e que as empresas se tornem parceiras dos outros dois atores nas ações para o desenvolvimento (MAGALHÃES et al., 2012).

O desenvolvimento de instituições que possuem o comportamento cooperativo acontece de maneira cumulativa, o que permite alcançar-se com mais facilidade soluções cooperativas, quando se mantém uma relação de confiança. As instituições que garantem o crescimento econômico e promovem a cooperação não surgem de maneira espontânea, desta maneira não se consegue copiar modelos prontos de instituições eficientes (BUENO, 2004).

A interação das universidades com a comunidade regional pode se dar devido:

\footnotetext{
$\checkmark$ ao número de vagas de cursos de graduação e pós graduação que atende aos anseios locais/regionais;

$\checkmark$ pela formação de recursos humanos;

$\checkmark$ pelo estímulo a interação universidadeempresa;

$\checkmark$ pela intensificação de pesquisas em áreas estratégicas do desenvolvimento regional; $\mathrm{e}$

$\checkmark$ pela ampliação das atividades de extensão. (GUMBOWAKY, 2014).
}

Para Fleck (2011, p. 287) as universidades podem ser vistas como fonte geradora de qualificação para o desenvolvimento do mercado de trabalho, sendo que:

A necessidade de qualificação destacada pelas pesquisas em gestão de pessoas volta-se para um objetivo mais amplo, que se dá na forma 
como um maior número de pessoas qualificadas é capaz de transformar-se em competência territorial e consequentemente em êxito territorial.

$>\mathrm{O}$ progresso vem do desenvolvimento da pesquisa dentro das universidades. Atualmente, as universidades passam por um processo de exigência constante para o desenvolvimento de pesquisas e os órgãos de fomento apenas reconhecem aquelas que conseguem habilitar-se com grupos e projetos estabelecidos.

Outro ponto importante com implicância no desenvolvimento regional, é que as políticas institucionais são aprovadas pelos colegiados das universidades, e estas podem estar com maior ou menor articulação aos programas que visem o desenvolvimento regional. Considerando que a sociedade possui assento nestes colegiados, se faz necessário que ocorra uma participação efetiva de modo a levar aos colegiados, as necessidades da comunidade local (GUMBOWAKY, 2014).

Possuindo a universidade uma estrutura de gestão com a colaboração de colegiados, a tomada de decisão quanto à priorização de projetos de ensino, pesquisa e extensão, pode gerar seus efeitos, na região, a partir das prioridades estabelecidas. Por outro lado, também, as instituições regionais podem não demonstrar de modo claro à universidade, as necessidades da região, principalmente àqueles docentes cuja incumbência está na aplicação dos programas de ensino, pesquisa e extensão. A falta de entrosamento da universidade com a sociedade pode trazer prejuízos significativos para ambas as partes (GUMBOWAKY, 2014).

\subsubsection{Ações promovidas pelas ICES que contribuem com o desenvolvimento regional}

As IES por necessidade dos critérios de avaliação do Sistema Nacional de Avaliação da Educação Superior (SINAES) são avaliadas sob a ótica de dez dimensões, as quais foram estabelecidas na Lei $\mathrm{n}^{\circ}$ 10.861/2004. De acordo com o artigo terceiro da lei, a avaliação das instituições de educação superior tem por objetivo identificar o seu perfil e o significado de sua atuação, por meio de suas atividades, cursos, programas, projetos e setores, considerando as diferentes dimensões institucionais, dentre elas obrigatoriamente as seguintes: 
1 A missão e o Plano de Desenvolvimento Institucional - Peso 5

2 A política para o ensino, a pesquisa, a pósgraduação, a extensão e as respectivas normas de operacionalização, incluídos os procedimentos para estímulo à produção acadêmica, as bolsas de pesquisa, de monitoria e demais modalidades Peso 30

3 A responsabilidade social da instituição, considerada especialmente no que se refere à sua contribuição em relação à inclusão social, ao desenvolvimento econômico e social, à defesa do meio ambiente, da memória cultural, da produção artística e do patrimônio cultural. - Peso 10

4 A comunicação com a sociedade. - Peso 05

5 As políticas de pessoal, de carreiras do corpo docente e corpo técnico-administrativo, seu aperfeiçoamento, desenvolvimento profissional e suas condições de trabalho - Peso 20

6 Organização e gestão da instituição, especialmente o funcionamento $\mathrm{e}$ representatividade dos colegiados, sua independência e autonomia na relação com a mantenedora, e a participação dos segmentos da comunidade universitária nos processos decisórios. - Peso 05

7 Infraestrutura física, especialmente a de ensino e de pesquisa, biblioteca, recursos de informação e comunicação. - Peso 10

8 Planejamento e avaliação, especialmente em relação aos processos, resultados e eficácia da autoavaliação institucional. - Peso 05

9 Políticas de atendimento aos estudantes. Peso 05

10 Sustentabilidade financeira, tendo em vista o significado social da continuidade dos compromissos na oferta da educação superior Peso 05

Assim, verifica-se que as dimensões de número dois, três, quatro e seis, são as que mais envolvem a interação das IES com a comunidade e representam $50 \%$ do peso da avaliação institucional. Entre as 
dimensões citadas, estão as atividades de extensão e pesquisa e o envolvimento da comunidade organizada nos conselhos representativos das instituições de ensino superior.

Em 2014, com a reorganização do processo avaliativo do SINAES, as dimensões foram agrupadas em cinco eixos, conforme quadro 02:

Quadro 02 - Eixos de avaliação do SINAES

\begin{tabular}{|c|l|c|c|}
\hline Eixos & \multicolumn{1}{|c|}{ Descrição } & Dimensões & Peso \\
\hline 1 & Planejamento e Avaliação Institucional & 8 & 5 \\
\hline 2 & Desenvolvimento Institucional & 1 e 3 & 15 \\
\hline 3 & Politicas Acadêmicas & 2,4 e 9 & 40 \\
\hline 4 & Politicas de Gestão & 5,6 e 10 & 30 \\
\hline 5 & Infra estrutura Fisica & 7 & 10 \\
\hline & & & \\
\hline
\end{tabular}

Fonte: dados da pesquisa.

No quadro 06 (mais adiante) demonstra-se que os maiores pesos nas avaliações das IES, estão nos eixos 03, referente às políticas acadêmicas e no eixo 04 políticas de gestão que quando somadas, representam $70 \%$ do peso da avaliação das instituições de ensino superior. Nestes eixos encontram-se as dimensões que contribuem para caracterizar as ações praticadas pelas ICES no seu dia a dia, que podem contribuir para o desenvolvimento regional, conforme descreve as dimensões a seguir:

No eixo 03 contemplam-se as seguintes dimensões:

Dimensão 2 - A política para o ensino, a pesquisa, a pós-graduação, a extensão e as respectivas normas de operacionalização, incluídos os procedimentos para estímulo à produção acadêmica, às bolsas de pesquisa, de monitoria e demais modalidades;

Dimensão 4 - A comunicação com a sociedade;

Dimensão 9 - Políticas de atendimento aos estudantes. 
No eixo 04 encontram-se:

Dimensão 5 - As políticas de pessoal, de carreiras do corpo docente e corpo técnicoadministrativo, seu aperfeiçoamento, desenvolvimento profissional e suas condições de trabalho;

Dimensão 6 - Organização e gestão da instituição, especialmente o funcionamento e representatividade dos colegiados, sua independência e autonomia na relação com a mantenedora, e a participação dos segmentos da comunidade universitária nos processos decisórios;

Dimensão 10 - Sustentabilidade financeira, tendo em vista o significado social da continuidade dos compromissos na oferta da educação superior;

As dimensões destes dois eixos principais, conforme exposto, demonstram características que são evidenciadas nas ICES em sua maioria, no cotidiano, principalmente no que tange às políticas de interação com a comunidade, nas ações de pesquisa e extensão, representatividade nas decisões e comunicação com a sociedade.

Os procedimentos de interação com a comunidade regional segundo Caldarelli, Câmara e Perdigão (2015, p. 88),

[...] podem ser simples, como a associação do nome de determinada instituição a uma ação regional, prestação de serviços à comunidade, iniciativas de extensão, como também podem ser de base complexa, em que se destaca pesquisa, geração de capital humano, interação para a formação de bases industriais regionais e mecanismos de geração de difusão de inovações.

Na figura 06, demonstra-se que a universidade por meio do ensino, pesquisa e extensão promovem a interação com a região onde tem atuação, gerando o bem-estar, inovações e valorizando a cultura. 
Figura 06 - Relação entre universidade e região

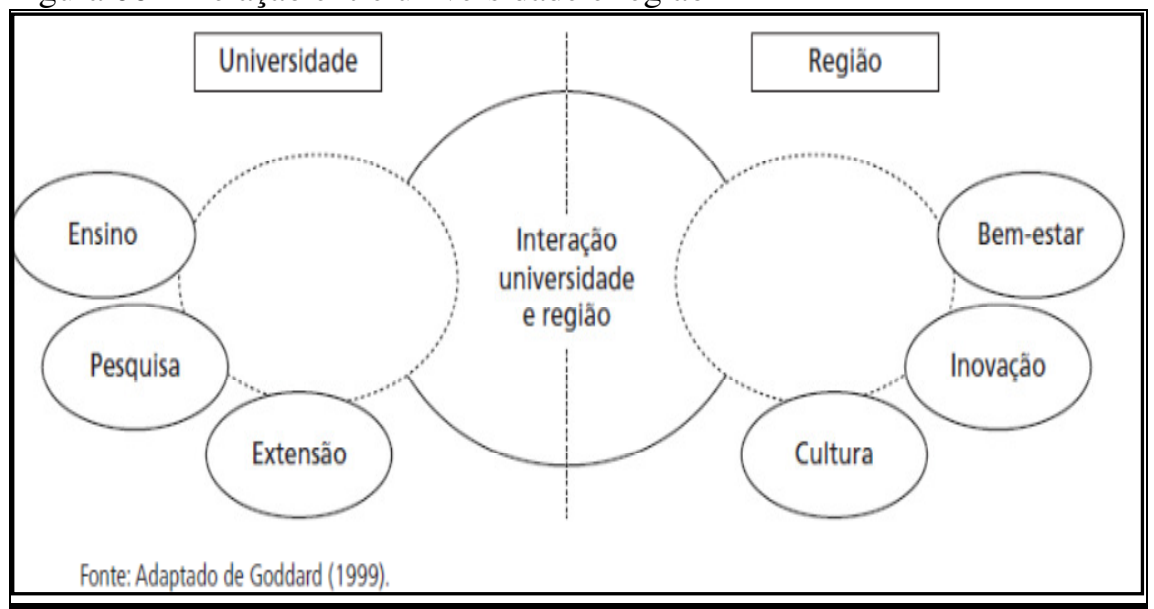

Fonte: Caldarelli, Camara e Perdigão (2015).

Conforme demonstrado na figura 06, entende-se que as atividades de pesquisa e extensão desenvolvidas pelas instituições de ensino, fazem com que se torne mais visível as evidências da inserção das instituições junto à comunidade regional de atuação, demonstrando a responsabilidade social destas IES com desenvolvimento regional.

Juntamente com a missão institucional as universidades incorporam o seu tripé pesquisa, ensino e extensão, que gira em torno da produção e transmissão do conhecimento, com objetivo da formação dos cidadãos. As atividades de extensão permitem a intervenção direta na realidade regional, sendo capazes de articular pesquisa e ensino num único processo, com vias à libertação do indivíduo num cenário marcado por intensa globalização e, por conseguinte, passível de perder os genuínos valores culturais (BRASILEIRO; GONÇALVES; TARGINO, 2014).

As instituições comunitárias, por meio das atividades de extensão e de pesquisa, também demonstram interação com a comunidade em que atuam, pois promovem diversas atividades que passam pela prestação de serviço como atividades culturais e de atendimentos dos mais diversos. Porém, a extensão universitária pode ser realizada de diversas maneiras, podendo ser via de ações de prestação de serviços à comunidade universitária e de seu entorno; oferecendo atendimento à comunidade; levando seu conhecimento por meio de cursos, seminários, laboratórios; 
e contribuindo para a melhoria da qualidade de vida da população (RIBEIRO, 2011, p. 87).

A relação entre a universidade e a sociedade se viabiliza por meio da extensão. Com a extensão ocorre a aproximação, a integração e a parceria da universidade e da comunidade, da ciência e dos saberes populares e culturais, resultando em novos conhecimentos para a sociedade (SANTOS JUNIOR, 2013).

Conforme o documento de Correa (2007, p. 36), denominado Extensão Universitária: Organização e Sistematização, elaborado em 2007, as ações de extensão universitária podem ser classificadas nas seguintes áreas temáticas: comunicação; cultura; direitos humanos e justiça; educação; meio ambiente; saúde; tecnologia e produção; trabalho. Quanto às ações de extensão, elas podem ser classificadas como:

$\checkmark$ Programas: Trata-se de um conjunto articulado de projetos integrados (ações, eventos, etc.), geralmente de médio-longo prazo, envolvendo ensino e pesquisa;

$\checkmark$ Projetos: Pode ou não ser vinculado a um programa. Deve ter objetivo específico e prazo determinado, além do caráter "educativo, social, cultural, científico, tecnológico";

$\checkmark$ Cursos: São caracterizados pela ação pedagógica (teórica e/ou prática), o que pressupõe planejamento e organização sistemática e critérios de avaliação definidos, além de carga horária mínima de 8 horas (presencial ou na modalidade a distância);

$\checkmark$ Eventos: congressos, seminários, ciclos de debates, exposições, espetáculos, eventos esportivos, festivais, entre outros;

$\checkmark$ Prestação de Serviço: É a "realização de trabalho oferecido pela Instituição de Educação Superior [...], se caracteriza por intangibilidade, inseparabilidade processo/produto e não resulta na posse de um bem" (BRASIL, 2007, p. 36). São exemplos: atendimentos jurídicos e judiciais, atendimentos psicopedagógicos, consultas ambulatoriais, exames laboratoriais, etc. 
Com base no apresentado até o momento, tentou-se evidenciar as maneiras e formas de interações que podem ocorrer entre as IES e as comunidades regionais em que atuam, demonstrando alguns reflexos das ações das universidades na contribuição do desenvolvimento regional. Entende-se, portanto, que as universidades também podem estar inseridas no que, atualmente, está se denominando como sociedade do conhecimento. Desta maneira, na seção seguinte, tentar-se-á demonstrar como as IES podem contribuir na sociedade do conhecimento.

\subsection{SOCIEDADE DO CONHECIMENTO}

As universidades comunitárias exercem um papel de significativa expressão na difusão do conhecimento nas regiões onde exercem suas atividades, por intermédio de seus cursos de graduação, pós ou extensão e vêm ao longo dos anos, contribuindo com conhecimento desenvolvido e criado nos municípios e arredores onde estão sediadas. Suas atividades de pesquisa e extensão contribuem com o conhecimento disseminado nas comunidades locais.

No cenário atual em que a sociedade se encontra, surgem, constantemente, novos grupos sociais e novos modelos econômicos, e neste contexto temos as IES, as quais podem contribuir com o entendimento e a organização destes grupos sociais. $\mathrm{O}$ mundo está interligado tecnologicamente e o conhecimento e a habilidade com as novas tecnologias são essenciais para a vida cotidiana, seja no ambiente do trabalho, ou no ambiente pessoal e familiar. Mas, apenas ter o acesso à informação, não é suficiente, faz-se necessário transformar as informações em conhecimento, o que implica em uma gestão criativa de informações na concepção de contextos globais, na compreensão do seu caráter multidimensional e nas relações entre o todo e cada uma das partes (CAVICHIOLI, 2011).

Segundo Mota (1999, p. 01) "no final da década de 1990, o processo de mudança tecnológica atingiu uma velocidade e importância nunca antes vista na história humana." Os meios de informações, o avanço tecnológico da dinâmica em um processo acelerado de novas descobertas e novas invenções e, o conhecimento transmitido nas instituições de ensino voltadas à pesquisa, vem contribuir com o processo.

Para Bernheim e Chauí (2008, p. 07), "uma das características da sociedade contemporânea é o papel central do conhecimento nos processos de produção, ao ponto do termo qualificativo mais frequente hoje empregado ser o de sociedade do conhecimento" (está cada vez 
mais, ficando em segundo plano e passando a se dar maior importância à obtenção e o uso do conhecimento e informação).

Vivencia-se atualmente, o momento de valorização do conhecimento, o qual permite o entendimento da evolução das organizações sociais, sejam elas políticas ou econômicas. Assim, o sucesso neste cenário permeia em saber capturar as informações, questioná-las, organizá-las e tecer críticas, bem como, saber empregá-las de modo a responder a algum problema atual, papel que as IES devem contribuir de maneira significativa para que aconteça (GUIMARÃES; MAGALHÃES, 2016).

Neste cenário pode se entender que as universidades podem agir e serem um dos agentes facilitadores, por intermédio das diversas maneiras de interação que atuam com a comunidade em seu entorno, podendo contribuir de maneira significativa para que o conhecimento originado pelo universo de informações compartilhadas, possa contribuir com o desenvolvimento e crescimento, seja econômico ou social das regiões em que atuam (CAVICHIOLI, 2011).

Ainda segundo Cavichioli (2011, p. 148), aprender é um processo complexo, no qual o ser humano deve ser o sujeito ativo na construção do conhecimento, e a ação do sujeito sobre a realidade é de extrema importância na sociedade da aprendizagem. Neste sentido, as ações das universidades por intermédio de suas atividades de pesquisa e extensão possam contribuir com a formação desse sujeito ativo na sociedade em que vive.

Para Cabelleira (2007, p. 01), enquanto soluções tecnológicas ditam a velocidade dos mecanismos de controle da gestão, as pessoas passam a configurar um valor de capital intangível de alto valor agregado nas estruturas organizacionais. A gestão de grupos de trabalho com maior autonomia se revela uma estratégia complexa, que pode causar mudanças profundas nas estruturas hierárquicas das organizações, porém pode contribuir de maneira significativa para o seu crescimento e desenvolvimento.

Com essas características, em que o conhecimento e a informação se tornam partes integrantes do capital, a hegemonia econômica deixa de pertencer apenas para o capital financeiro. Segundo Bernheim e Chauí (2008, p. 07), a informação prevalece sobre o conhecimento, pois o capital financeiro funciona com a riqueza puramente virtual, cuja existência corresponde à própria informação. Fato este que vem ocasionar que o poder econômico seja determinado pela detenção de mais ou menos informações, tornando o acesso às informações, cada vez mais difícil. 
Desta maneira, segundo Bernheim e Chauí (2008, p. 07),

[...] em lugar de prometer significativo progresso e desenvolvimento autônomo das universidades como instituições sociais, comprometidas com a vida das suas sociedades e articuladas a poderes diretos democráticos, a noção de sociedade do conhecimento sugere, ao contrário, tanto a heteronomia da universidade (quando ela produz conhecimento destinado a gerar mais informação para o capital financeiro, curvando-se às suas necessidades e à sua lógica), como a irrelevância da atividade universitária (quando a pesquisa é definida com autonomia pelas suas sociedades ou busca responder às suas necessidades sociais e políticas).

Mas, atualmente, as atividades promovidas pelas IES, constroem um banco de dados em que é repassado aos acadêmicos, um expressivo volume de conteúdo, sem incentivá-los a pensar, formando assim, apenas uma grande quantidade de alunos "banco de dados", os quais não conseguem articular os dados recebidos. A estrutura curricular de disciplinas ora proposta é um dos fatores que contribui para transferência engessada de informações (GUIMARÃES; MAGALHÃES, 2016).

Pode-se dizer, que o desenvolvimento do conhecimento permeia pela construção de uma visão integrada, com capacidade de pensamento crítico sobre os fatos, com capacidade de articulação e questionamentos das informações, devendo a educação permitir uma aptidão de maneira natural da mente, para formular e resolver problemas essenciais do dia a dia, sendo este o alvo a ser atingido pelas universidades dentro das suas funções (GUIMARÃES; MAGALHÃEES, 2016).

Porém, as universidades aparentemente passaram a ser organizações que administram contratos de prestações de serviços, sejam eles educacionais ou de pequenas atividades prestadas à comunidade do seu entorno. Passando a serem avaliadas pelos órgãos fiscalizadores, mediante indicadores de produtividade, sendo estruturada por processos de eficiência organizacional, normas e procedimentos distantes da formação intelectual. Desse modo, as instituições passam a ser pulverizadas em pequenas organizações e submetendo os alunos a exigências não relacionadas ao trabalho intelectual (BERNHEIM; CHAUÍ, 2008). 
O ensino é entendido hoje, apenas como transmissão de conhecimento. Segundo Bernheim e Chauí (2008, p. 13), “o ensino é concebido como uma habilitação rápida para os graduados que precisam ingressar imediatamente em um mercado de trabalho do qual serão eliminados alguns anos depois, ao tornaram-se obsoletos e dispensáveis", dessa maneira, ser docente faz uma pessoa apta apenas para a transmissão e treinamento de pessoas.

A universidade vem a ser uma instituição social que reflete a estrutura e o modo de funcionamento da sociedade como um todo, e dentro da universidade, se encontram opiniões, projetos e atitudes que se conflitam e refletem divisões e contradições, as quais são encontradas na sociedade como um todo. A universidade moderna fundamenta sua legitimidade, no pensamento de um conhecimento que é direcionado, pela lógica, tanto do ponto de vista de sua invenção, quanto da descoberta como a sua transmissão (BERNHEIM; CHAUÍ, 2008).

Nas experiências comuns compartilhadas e fortalecidas, as pessoas também compartilham valores pessoais e isso contribui com a identificação da organização. Quando estes valores são bem trabalhados, faz com que se crie uma cultura forte, em que a base cultural que é estabelecida nas organizações exerce papel de grande significado para o sucesso ou fracasso de novas estratégias que se pretendem implementar (CABELLEIRA, 2007).

Conforme Bernheim e Chauí (2008, p. 21), a Declaração Mundial sobre a Educação Superior para o Século XXI: visão e ação - inclui os seguintes conceitos com respeito à pertinência, os quais refletem a complexidade e a abrangência da missão social da educação superior contemporânea:

a) A pertinência da educação superior deve ser avaliada em função da adequação entre o que a sociedade espera das instituições e o que estas fazem. Isto exige padrões éticos, imparcialidade política, capacidade crítica e, ao mesmo tempo, melhor articulação com os problemas da sociedade e do mundo do trabalho, baseando as orientações de longo prazo em objetivos e necessidades societais, compreendidos o respeito pelas culturas e a proteção ambiental. A preocupação é de abrir acesso tanto à educação geral ampla como à educação especializada, específica para determinadas carreiras, muitas vezes 
interdisciplinar, centrada nas competências e aptidões, pois ambas preparam os indivíduos a viverem em situações diversas e a poder mudar de ocupação.

b) A educação superior deve reforçar seu papel de prestadora de serviço à sociedade, especialmente orientada a erradicar a pobreza, a intolerância, a violência, o analfabetismo, a fome, a doença e a degradação ambiental, sobretudo mediante uma abordagem interdisciplinar e transdisciplinar na análise dos problemas e das questões.

c) A educação superior deve fortalecer sua contribuição ao desenvolvimento de todo o sistema educacional, sobretudo para o aperfeiçoamento dos docentes, do desenvolvimento curricular e da pesquisa educacional.

d) Finalmente, a educação superior deve visar a criação de uma nova sociedade, não violenta e não-exploradora, formada por indivíduos altamente esclarecidos, motivados e integrados, inspirados pelo amor à humanidade e guiados pela sabedoria.

O avanço da sociedade do conhecimento proporciona, de maneira significativa, mudanças no desenvolvimento econômico de regiões e países. Segundo Mota (1999, p. 01) "a valorização das atividades de ciência e tecnologia e de pesquisa e desenvolvimento, para estados nacionais e empresas, são evidências claras de processo".

Mas, a dinâmica da inovação, não acontece sem estar vinculada aos processos de aprendizagem do conhecimento. Assim está diretamente vinculada aos processos de interação entre as organizações e agentes que permitem gerar, reproduzir e retroalimentar processos de aprendizagem, convertendo-os em atividades inovadoras. Porém, na América latina, ainda falta, a existência de uma linguagem comum entre empresários e pesquisadores, de modo que possam trabalhar de maneira colaborativa e assim avançarem no campo de desempenho de busca de inovações ao processo produtivo ou de criação de novos produtos (MOTA, 1999).

Os objetivos das universidades e das empresas são bem diferenciados. Porém, ambos fazem parte de um sistema e devem interagir de maneira a conseguir aumentar as possibilidades de 
benefícios para os seus objetivos e para a sociedade. No entanto, para que isso aconteça, requer um esforço destas instituições, de maneira que esta interação possa ser iniciada e mantida. $O$ principal benefício para a universidade é o conhecimento que ela adquire, sobre o funcionamento e a necessidade das instituições para as quais ela está formando recursos humanos, pois na universidade é o ambiente em que se constitui um reservatório de conhecimentos muito variados que podem se reunir em outras instituições (MOTA, 1999).

Segundo Mota (1999, p. 04), "podemos afirmar que o processo de parceria universidade-empresa segue algumas fases que se iniciam no diálogo, intensificam-se com a convivência, até atingir a identificação cultural e a confiança". Existem diversas maneiras de se iniciar o diálogo, como: a participação em congressos, exposições e feiras; visitas programadas às empresas; visitas de empresários a centros de pesquisa universitários; debates científicos sobre temáticas previamente definidas.

Para Bernheim e Chauí (2008, p. 30), "é importante promover um relacionamento mais estreito e mutuamente benéfico entre os setores universitário e produtivo." Porém, em muitos países o distanciamento entre estas duas esferas é muito grande, na qual ambas ignoram a existência uma da outra, e o setor produtivo e industrial não toma conhecimento do trabalho feito nas universidades no campo da pesquisa e suas possíveis aplicações tecnológicas.

A relação entre universidade e o setor produtivo está relacionado com o futuro da educação superior em conseguir responder às necessidades de todos os setores da sociedade, entre eles o mundo do trabalho ou emprego. As instituições de educação superior precisam se voltar para as mudanças do mundo do trabalho e além de preparar os trabalhadores para tarefas específicas devem prepará-los para a "empregabilidade", analisando as principais tendências do trabalho (BERNHEIM; CHAUÍ, 2008).

Para Nunes e Silva (2011, p. 04), uma das responsabilidades da IES é "preparar profissionais com domínio da linguagem técnica, em condições de utilizar novos equipamentos e capacidade de processar novas informações além de interferir de forma mais direta na sociedade em que está inserida". Desta maneira, a globalização transfere o destaque do capital físico, para o capital humano e intelectual, e a preocupação com a preservação dos recursos de grande volatilidade. Pode-se destacar que o único fator permanente de riqueza nesse ciclo vicioso é o homem, e a sua capacidade intelectual e de conhecimento (NUNES; SILVA, 2011). 
Assim, segundo Correa, França e Bezerra (2015, p. 09):

[...] é necessário que haja uma conscientização de todos - organizações, governos, indivíduos - no sentido de que a sociedade só será totalmente "do conhecimento" a partir do momento em que, se não todos, ao menos a maioria das pessoas puder ter acesso aos conteúdos disponíveis e participar ativamente da construção do conhecimento interativamente, pensando na coletividade e propiciando compartilhar o saber, de modo e tornar a sociedade mais justa e igualitária.

Desta maneira, em frente aos problemas que o capitalismo globalizado evidencia, se faz necessário a união entre a prática e a teoria, ou seja, as pesquisas, projetos e conhecimentos produzidos nas universidades precisam ser auxiliados pela realidade, na medida em que essa fornece elementos propulsores para novos estudos. Assim, o conhecimento produzido pelas IES de pesquisa, deve ter intenções de transformar a realidade social, intervindo em suas deficiências e não se limitando apenas à formação de alunos regulares da instituição (NUNES; SILVA, 2011).

Com isso, torna-se de extrema importância que ocorra um pensar coletivo, de maneira que, com a elaboração de ideias, as instituições possam trazer benefícios à sociedade. Nesse caso, as empresas privadas, órgãos públicos e cidadãos precisam estar engajados com o mesmo propósito, e além de ser necessário trabalhar o senso crítico e a habilidade de transformar informações desconexas em conteúdo significativo, de modo que a tecnologia possa ser realmente utilizada a favor das pessoas, empresas e da sociedade como um todo (CORREA; FRANÇA; BEZERRA, 2015).

Segundo Nunes e Silva (2011, p. 05), “a universidade pública enquanto um espaço de criação e recriação de conhecimento deve ser acima de tudo pública e, para tanto, a transformação social deve extrapolar os muros acadêmicos", portanto, as instituições de ensino devem ser mais do que um laboratório, objeto de estudo ou campo de pesquisas, mas também uma instituição com pessoas, demandas, reivindicações, anseios e saberes que se encontram dentro e fora da universidade (NUNES; SILVA, 2011).

Ainda segundo Nunes e Silva (2011, p. 08), “a relação entre pesquisa e extensão ocorre quando a produção do conhecimento é capaz de contribuir para a transformação da sociedade." Porém, ainda não 
existe a preocupação dos órgãos de financiamento e gestão do ensino e da ciência em dedicar atenção para as atividades de extensão, fato que faz com que ocorra uma grande perda de um elo de interação entre a universidade e a sociedade, com prejuízo para ambas.

Nesta seção da dissertação, procurou-se demonstrar a importâncias das IES para o desenvolvimento e crescimento regional, por intermédio das diversas ações que podem e conseguem promover nas regiões em que atuam. Após a pesquisa bibliográfica pretendeu-se verificar se as ICES catarinenses possuíam práticas semelhantes que podem caracterizá-las como agentes promotores do desenvolvimento regional na sociedade do conhecimento.

Assim, no próximo capítulo, apresentam-se os procedimentos metodológicos adotados para realizar a pesquisa e alcançar os objetivos. 


\section{PROCEDIMENTOS METODOLÓGICOS}

Com base no princípio da interação das IES como agentes propulsores do desenvolvimento regional, propôs-se, realizar um estudo nas universidades comunitárias, pertencentes ao Sistema ACAFE, sobre a interação dessas instituições com a comunidade regional de atuação, tentando evidenciar suas formas de envolvimento com a comunidade.

Delimita-se como lócus de estudo da pesquisa as ICES com as seguintes características:

$\checkmark \quad$ Instituições Comunitárias de Educação Superior (ICES);

$\checkmark$ Universidades;

$\checkmark$ Pertencentes à ACAFE; e

$\checkmark$ Maior representatividade nas mesorregiões de atuações.

\subsection{ENQUADRAMENTO METODOLÓGICO}

O presente trabalho caracteriza-se como interdisciplinar. Segundo Philippi Junior e Neto (2011, p. 40), "interdisciplinaridade é a aximática comum de grupo de disciplinas conexas, definida em nível ou subnível hierárquico imediatamente superior, o que introduz uma noção de finalidade". Ainda de acordo com Philippi Junior e Neto (2011, p. 50):

Interdisciplinar é a interação existente entre duas ou mais disciplinas, podendo ir da simples comunicação de ideias até a integração mutua dos conceitos diretos, da epistemologia, da terminologia, metodologia, dos procedimentos, dos dados e da organização da pesquisa e do ensino a elas relacionados.

Caracteriza-se este trabalho de pesquisa como interdisciplinar, por entender que possui relacionamento com diversas áreas do conhecimento, entre elas: ciências econômicas, história, sociologia, ciências políticas, administração, direito, entre outras.

Com relação aos objetivos, entende-se, como uma pesquisa descritiva e exploratória, em que a pesquisa exploratória tem como objetivo tornar mais explicito o problema e aprofundar as ideais sobre o estudo. Referente a ser descritiva, é porque este tipo de pesquisa descreve as características de uma população ou de um fenômeno, ou até mesmo estabelece relações entre os fenômenos (ALVES, 2007). 
Com relação ao tipo de pesquisa identifica-se como uma pesquisa bibliográfica documental, a qual é desenvolvida exclusivamente, a partir de fontes já elaboradas, livros, artigos científicos, publicações periódicas, as chamadas fontes de papel (ALVES, 2007). Também pode ser caracterizada como uma pesquisa de levantamento, que possui como características a interrogação direta das pessoas, cujo comportamento se deseja conhecer, procede-se a solicitação de informação a um grupo significativo de pessoas acerca do problema estudado, para em seguida, mediante a abordagem quantitativa, obterem-se as conclusões correspondentes aos dados coletados (GIL, 2008).

Referente à abordagem caracteriza-se como uma pesquisa mista e, segundo Creswell (2010, p. 27), "é uma abordagem da investigação que combina ou associa as formas qualitativas e quantitativas. Envolve suposições filosóficas, o uso de abordagens qualitativas e quantitativas e a mistura das duas abordagens em um estudo." Para a coleta de dados foram realizadas treze entrevistas semiestruturadas com dirigentes das entidades da comunidade organizada da região de atuação das universidades, assim como dos dirigentes das ICES.

Com relação à pesquisa qualitativa entende-se como um meio, para explorar e para obter, o entendimento do significado que os indivíduos ou os grupos atribuem a determinados problemas sociais ou humanos (CRESWELL, 2010). Na pesquisa qualitativa, o pesquisador procura captar a situação ou fenômeno em toda a sua extensão, trata de levantar possíveis variáveis existentes e na sua interação, o verdadeiro significado da questão, daí a experiência do pesquisador ser fundamental (ALVES, 2007).

Com relação à concepção da pesquisa, entende-se ser uma pesquisa construtivista, a qual se caracteriza por ter como objetivo, confiar o máximo possível nas visões que o participante tem da situação a qual está sendo estudada. Sendo a intenção do pesquisador, extrair sentido dos significados que os outros atribuem ao mundo; os pesquisadores geram ou indutivamente desenvolvem uma teoria ou padrão de significado (CRESWELL, 2010).

A estratégia utilizada compreende ser um estudo com procedimentos mistos concomitantes, o qual, segundo Creswell (2010, p. 39), "são aqueles em que o pesquisador converge ou mistura dados quantitativos e qualitativos para realizar uma análise abrangente do problema da pesquisa."

A pesquisa utiliza-se de métodos mistos com coleta sequencial de dados quantitativos e qualitativos. Segundo Creswell (2010, p. 43), “o pesquisador baseia a investigação na suposição de que a coleta de 
diversos tipos de dados proporciona um melhor entendimento do problema da pesquisa." A pesquisa inicia com o levantamento amplo para poder generalizar os resultados para uma população. Na segunda fase concentra-se em entrevistas qualitativas abertas visando a coletar pontos de vista detalhadas dos participantes.

\subsection{CÁLCULO DO ÍNDICE DE INSERÇÃO REGIONAL DAS ICES}

Para definir o Índice de Inserção Regional (IIR) das ICES, foi utilizada a metodologia de cálculo dos Índices de Inserção Regional das IES, aplicado por Rolim (2009), ao calcular o IIR das universidades federais. A proposta inicial do cálculo do IIR considerava quatro dimensões de impacto de uma IES sobre a região em que ela está inserida, subdivididas em subdimensões.

1. Dimensão: Contribuição da Pesquisa à Inovação Regional;

$2^{\mathrm{a}}$. Dimensão: Contribuição do Ensino e Aprendizado ao Mercado de Trabalho e à Profissionalização;

$3^{\mathrm{a}}$. Dimensão: Contribuição ao Desenvolvimento Social, Cultural e Ambiental; e

4. Dimensão: Capacitação Para a Cooperação Regional;

Para cada subdimensão deve ser construído um índice, e após calculados os $i$ índices, chega-se ao índice agregado para aquela dimensão, que é a média aritmética simples desses $i$ índices. Repetindose o processo para cada uma das quatro dimensões consideradas, obtémse o indicador procurado, que pode ser provisoriamente chamado de Índice de Inserção Regional (IIR), o qual consiste na média aritmética simples das quatro dimensões.

\section{O IIR irá variar entre 0 e 1. Quanto mais próximo de 1 maior será o grau de integração da IES com a região.}

Devido a dificuldade de informações, a proposta efetivada por Rolim (2009) para o cálculo do IIR, foi a partir das informações relativas às atividades de extensão universitária, e foi possível coletar informações que permitissem obter algumas indicações dos elementos presentes na segunda dimensão proposta inicialmente, (contribuição do 
ensino e aprendizagem ao mercado de trabalho e à profissionalização), e, terceira dimensão (contribuição ao desenvolvimento social, cultural e ambiental) apresentadas no item anterior.

A proposta final para o cálculo do IIR foi construída com base em quatro dimensões:

1. A primeira dimensão considera os projetos de extensão universitária e o público atingido por eles;

2. A segunda dimensão considera os cursos presenciais de extensão universitária e o público atingido;

3. A terceira dimensão considera os cursos a distância de extensão universitária e o público atingido; e

4. A quarta dimensão considera a prestação de serviços institucionais.

Para as dimensões propostas foram consideradas as seguintes características de informações:

\section{A primeira dimensão - relativa aos projetos de extensão realizados e ao público atingido por esses projetos.}

Foram considerados os projetos integrantes de um programa estabelecido de extensão universitária. Segundo o Instituto Nacional de Estudos e Pesquisa (INEP) um programa de extensão universitária é um conjunto articulado de projetos e de outras ações de extensão (cursos, eventos, prestação de serviços) com clareza de diretrizes e orientação para um objetivo comum, executado a médio e longo prazo. Embora muitas universidades também desenvolvam atividades de extensão não vinculadas aos programas, considerou-se que os projetos vinculados a um programa demonstram uma atividade com maior consistência e permanência no tempo (ROLIM, 2009).

Foram considerados, portanto, todos os projetos de extensão vinculados a um programa e o público atingido por eles. Esses projetos atenderam as seguintes áreas temáticas: comunicação, cultura, direitos humanos e justiça, educação, meio ambiente, saúde, tecnologia e produção, trabalho. Assim, para cada universidade essa dimensão foi composta pela somatória de todos os projetos de todas as áreas temáticas, ponderados pelo número total de professores da IES, mais a somatória de todo o público respectivamente atingido por eles, ponderado também pelo número total de professores da IES. 
2 A segunda dimensão foram os cursos de extensão presenciais (com até 30 horas) e o número de alunos que eles atenderam e foram aprovados.

Esses cursos devem ter no mínimo oito horas e ter um processo de avaliação formal. Neste caso foi dada uma ponderação maior aos cursos mais imediatamente voltados para a produção industrial e agrícola, bem como aqueles voltados para as áreas médicas. Isso porque se considera que em decorrência da necessidade de maior quantidade de equipamentos que esses cursos requerem, a sua oferta implica em um esforço maior das universidades. Dessa forma, tanto o número de cursos como o número de participantes foram multiplicados por 2. Esse critério obviamente é criticável, mas a sua introdução, objetiva apenas realçar o maior grau de dificuldade enfrentado. As demais áreas ciências exatas e da terra, ciências sociais aplicadas, ciências humanas, linguística, letras e artes- tiveram peso 1.

Desta maneira, para cada universidade, essa dimensão foi composta pela somatória de todos os cursos de todas as áreas do conhecimento, e algumas com peso 2. Ponderados pelo número total de professores da IES mais a somatória de todo o público respectivamente atingido por eles, ponderado também pelo número total de professores da IES.

\section{A terceira dimensão considerou os cursos de extensão a distância (com até 30 horas) e o público por ele atingido}

O mesmo tipo de ponderação utilizado na dimensão anterior para os diferentes conjuntos de áreas do conhecimento foi aplicado. Também todas as informações foram divididas respectivamente pelo número total de professores da IES.

Deve ser salientado que esse tipo de curso representa uma das tendências mais recentes do ensino superior em todo o mundo. É particularmente empregado em programa de formação continuada e lifelong learning.

\section{A quarta dimensão considerada foi a prestação de serviços institucionais}

Refere-se à realização de trabalhos oferecidos pela IES ou contratados por terceiros (comunidade ou empresa). A prestação de serviços engloba sete tipos e cada um deles pode atender a oito áreas do 
conhecimento. Cada tipo de prestação de serviços também pode ter subdivisões, conforme a seguir.

4.1 - Atendimento ao público em espaços de cultura, ciência e tecnologia

$\checkmark$ Espaços e museus culturais;

$\checkmark$ Espaços e museus de ciência e tecnologia;

$\checkmark$ Cines-clube;

$\checkmark$ Outros;

4.2 - Serviço eventual

$\checkmark$ Número de assessoria;

$\checkmark$ Número de consultoria;

$\checkmark$ Número de curadoria;

$\checkmark$ Número de outros;

4.3 - Atividades de propriedade intelectual

$\checkmark$ Número de depósitos de patentes e modelos de utilidades;

$\checkmark$ Número de registro de marcas e softwares;

$\checkmark$ Número de contratos de transferência de tecnologia;

$\checkmark$ Número de registros de direitos autorais;

\section{4 - Exames e laudos técnicos}

$\checkmark$ Número de laudos emitidos;

\section{5 - Atendimento jurídico}

$\checkmark$ Número de atendimentos;

\section{6 - Atendimento em saúde humana}

$\checkmark$ Número de consultas ambulatoriais (programadas);

$\checkmark$ Número de consultas de emergência e de urgência;

$\checkmark$ Número de internações;

$\checkmark$ Número de cirurgias;

$\checkmark$ Número de exames laboratoriais;

$\checkmark$ Número de exames complementares;

$\checkmark$ Número de outros atendimentos;

\section{7- Atendimento em saúde animal}

$\checkmark$ Número de atendimentos veterinários ambulatoriais;

$\checkmark$ Número de internações veterinárias;

$\checkmark$ Número de cirurgias veterinárias;

$\checkmark$ Número de exames laboratoriais e complementares em veterinária;

Cada uma das sub-dimensões será composta pela somatória dos diferentes tipos de serviços que prestam em cada área de conhecimento, ponderadas pelo número total de professores da IES. O índice final da 
quarta dimensão é obtido pela média aritmética dos índices das sete subdimensões. Para o cálculo do índice final de cada universidade é determinada a média aritmética dos quatro índices obtidos em cada dimensão.

Cabe lembrar que as universidades consideradas têm uma variação muito grande de dimensão. Dessa forma, para tornar os valores comparáveis, cada indicador foi ponderado pelo número total de professores. Ou seja, os valores considerados representam a proporção da variável em relação ao número total de professores em exercício na universidade.

\subsection{METODOLOGIA DE CÁLCULO DO IIR APLICADO}

Com base na metodologia proposta, considerando algumas adequações no que diz respeito às informações que irão compor as dimensões pré-estabelecidas, de modo a adequar a realidade das ICES de Santa Catarina, se propõe a calcular o IIR com as seguintes informações,

$>$ Primeira dimensão - relativa aos projetos de extensão realizados e ao público atingido por esses projetos.

$\checkmark$ Projetos integrantes de um programa estabelecido de extensão universitária;

$\checkmark$ Público atingido;

$\checkmark$ Áreas temáticas, comunicação, cultura, direitos humanos e justiça, educação, meio ambiente, saúde, tecnologia e produção, trabalho;

$\checkmark$ Projetos vinculados a um programa que demonstram uma atividade com maior consistência e permanência no tempo;

Esta dimensão será composta pela somatória de todos os projetos de todas as áreas temáticas, ponderados pelo número total de professores da IES, mais a somatória de todo o público respectivamente atingido por eles, ponderado também pelo número total de professores da IES.

A segunda dimensão considerada foram os cursos de extensão presenciais (com até 30 horas) e o número de alunos que eles atenderam e foram aprovados.

$\checkmark$ Cursos com no mínimo oito horas e ter um processo de avaliação formal. 
$\checkmark$ Será dada uma ponderação maior aos cursos mais imediatamente voltados para as áreas médicas (devido à decorrência da necessidade de maior quantidade de equipamentos que esses cursos requerem. A sua oferta implica em um esforço maior das universidades). Dessa forma tanto o número desses cursos como o número de participantes foi multiplicado por 2 .

$\checkmark$ As demais áreas das ciências exatas e da terra, ciências sociais aplicadas, ciências humanas, linguística, letras e artes tiveram peso 1 .

Essa dimensão será composta pela somatória de todos os cursos de todas as áreas do conhecimento, e algumas delas com peso 2, ponderados pelo número total de professores da IES, mais a somatória de todo o público respectivamente atingido por eles, ponderado também pelo número total de professores da IES.

$>$ A terceira dimensão a ser considerada são os cursos de extensão à distância (com até 30 horas) e o público por ele atingido.

$\checkmark$ O mesmo tipo de ponderação utilizado na dimensão anterior para os diferentes conjuntos de áreas do conhecimento foi aplicado. Também todas as informações foram divididas respectivamente pelo número total de professores da IES.

A subdivisão 04, refere-se a prestação de serviço institucional:

$>$ A quarta dimensão considerada foi a prestação de serviços institucionais.

$\checkmark$ Refere se à realização de trabalho oferecido pela IES ou contratado por terceiros (comunidade ou empresa). A prestação de serviços engloba sete tipos e cada um deles pode atender a oito áreas do conhecimento.

Cada tipo de prestação de serviços também pode ter subdivisões:

4.1 - Atendimento ao público em espaços de cultura, ciência e tecnologia

$\checkmark$ Espaços e museus culturais;

$\checkmark$ Espaços e museus de ciência e tecnologia;

$\checkmark$ Cines-clube;

$\checkmark$ Outros;

\section{2 - Serviço eventual}

$\checkmark$ Número de assessoria; 
$\checkmark$ Número de consultoria;

$\checkmark$ Número de curadoria;

$\checkmark$ Número de outros;

\section{3 - Atividades de propriedade intelectual}

$\checkmark$ Número de depósitos de patentes e modelos de utilidades;

$\checkmark$ Número de registro de marcas e softwares;

$\checkmark$ Número de contratos de transferência de tecnologia;

$\checkmark$ Número de registros de direitos autorais;

\section{4 - Exames e laudos técnicos}

$\checkmark$ Número de laudos emitidos;

\section{5 - Atendimento jurídico}

$\checkmark$ Número de atendimentos;

\section{6 - Atendimento em saúde humana}

$\checkmark$ Número de consultas ambulatoriais (programadas);

$\checkmark$ Número de consultas de emergência e de urgência;

$\checkmark$ Número de internações;

$\checkmark$ Número de cirurgias;

$\checkmark$ Número de exames laboratoriais;

$\checkmark$ Número de exames complementares;

$\checkmark$ Número de outros atendimentos;

Foi acrescentada a quinta dimensão, a qual se refere aos cursos de Pós-graduação Lato Sensu Presencial e aos cursos de Pós-graduação Stricto Sensu:

\section{$>$ Quinta dimensão - Programas de Pós-graduação Lato e Stricto Sensu \\ $\checkmark$ Número de Cursos de Pós-graduação Lato Sensu; \\ $\checkmark$ Número de Programas de Stricto Sensu; \\ $\checkmark$ Número de Grupos de Pesquisas Vinculados aos PPGs;}

Justifica-se a inclusão de uma quinta dimensão na análise do índice, por considerar que os cursos de pós-graduação Lato Sensu oportunizam uma especialização após a conclusão da graduação e uma melhor qualificação profissional. Se as instituições possuem bons cursos, os egressos irão retornar à instituição. Está é uma das maneiras das universidades estarem contribuindo com a inserção dos seus egressos no mercado de trabalho.

Com relação aos Programas Stricto Sensu, justifica-se, por considerar que estes programas consolidam grupos de pesquisas, que visam a contribuir com o desenvolvimento da região, onde as pesquisas 
buscam entender os problemas locais e propor novas alternativas para solução e melhorias de processos e de novas possibilidades.

\subsection{PROCEDIMENTOS DE COLETA DE DADOS}

Para realizar a coleta das informações necessárias para o cálculo do IIR, primeiro foi realizado contato, via ACAFE, com dirigentes de seis universidades do Sistema, contemplando as mesorregiões do estado de Santa Catarina. Os dados iniciais para o cálculo do IIR foram coletados via instrumento, com base no detalhamento das cinco dimensões propostas, solicitando-se o histórico dos últimos cinco anos.

Figura 07 - Mapa do estado de Santa Catarina com as universidades da rede ACAFE

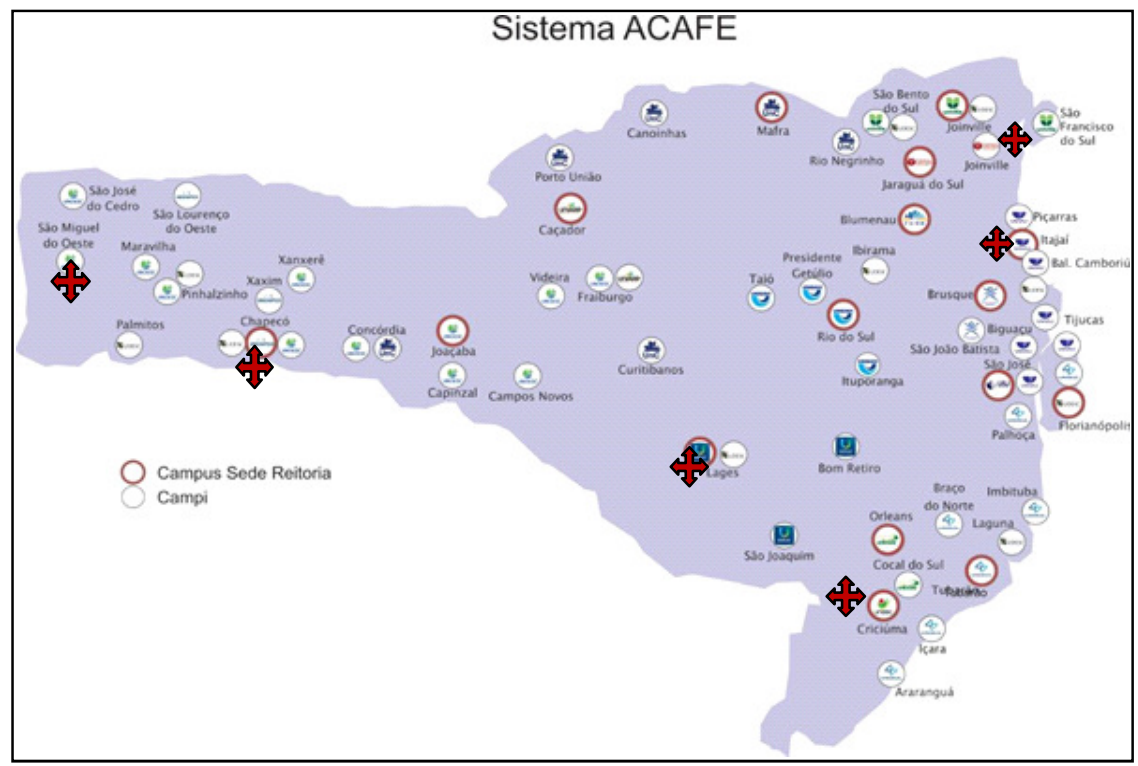

Fonte: Site da ACAFE (2016).

Além do cálculo do IIR das ICES, foram realizadas entrevistas com os dirigentes das seis universidades. O questionário base da entrevista buscou compreender junto aos dirigentes das ICES, se as ações promovidas pela Instituição estavam interagindo com a comunidade e contribuindo com a promoção do desenvolvimento regional por intermédio de suas ações de ensino, pesquisa e extensão. 
Também foram realizadas entrevistas com os representantes das associações empresarias dos municípios sedes das ICES, visando verificar se as atividades praticadas pelas instituições e as propostas definidas e divulgadas por elas, são percebidas da mesma maneira pela comunidade organizada local e regional. Em síntese, esta pesquisa buscou avaliar se as ações e atividades de inserção comunitária divulgadas pelas instituições de ensino são conhecidas pela sociedade organizada da região, como ações que efetivamente contribuem para o desenvolvimento do entorno da universidade e da comunidade.

A fórmula de cálculo do IIR é o a seguinte:

$$
I s d i j=\frac{S d i j-X s d i \text { minimo }}{X s d i \text { máximo }-X s d i \text { minimo }}
$$

Sendo que:

Isd $\mathrm{ij}$ = Índice da subdimensão i na IES j;

Xsd ij = Valor que a subdimensão i assume na IES j;

Xsd $\mathrm{i}$ máximo $=$ Valor máximo que a subdimensão $\mathrm{i}$ assume no conjunto das IES;

Xdi mínimo = Valor mínimo que a subdimensão i assume no conjunto das IES;

Após o cálculo dos índices, chega-se ao índice agregado para a dimensão, que é a média aritmética simples desses $\boldsymbol{i}$ índices. O processo é repetido para cada uma das cinco dimensões consideradas se obtém o indicador procurado, o qual será denominado de Inserção Regional (IIR), o qual consiste na média aritmética simples das quatro dimensões. A fórmula final do índice para cada uma das $j$ IES consideradas é a que segue:

$$
I I R=\frac{I d 1+I d 2+I d 3+I d 4+I d 5}{5}
$$

O IIR irá variar entre 0 e 1 . Quanto mais próximo de 1 maior será o grau de integração com a sua região de uma IES.

\subsubsection{Os percalços e dificuldades no caminho}

As dificuldades para conclusão desta pesquisa foram significativas, desde o seu princípio surgiram algumas dificuldades, iniciando pela própria definição do objeto de pesquisa, e o projeto de 
pesquisa foi construído e reconstruído por inúmeras vezes, mais sempre permanecendo com o foco nas universidades comunitárias. Após a definição do objetivo da pesquisa e defesa do projeto, passou-se para a fase de construção da primeira parte da pesquisa para a qualificação, período este que passou próximo de 05 meses e aí surge o primeiro obstáculo a ser vencido, pois no dia da qualificação devido a um acidente esportivo estava com o pé direito engessado.

Vencida esta etapa e a qualificação concluída, passou-se para a pesquisa de campo, em que a dificuldade maior, além da distância, foi conseguir conciliar as agendas para que no segundo semestre de 2016 pudesse realizar as 13 entrevistas realizadas. Assim foram realizadas as primeiras viagens para Chapecó e Lages. A viagem foi de criciúma a Chapecó direto parando apenas para o almoço, e depois de realizada a entrevista com o reitor da UNACHAPECO, retornou para Lages para o pernoite, pois no dia seguinte realizaria as três entrevistas em Lages. Nesta viagem a primeira aventura, na descida da serra do rio do rastro em uma sexta feira a noite, não se conseguia ver um metro a frente, devido à serração, mas com muito cuidado e cautela, conseguiu-se seguir viagem e chegar com segurança.

Em outro momento tive que ir até São Miguel do Oeste, então vivenciei outra aventura, pois durante o dia estive em Chapecó para um compromisso profissional e no início da noite em destino a cidade de São Miguel do oeste, iniciou-se um temporal com muita chuva e vento, e, a viagem que era para durar de duas a três horas, durou quase cinco horas.

As entrevistas em Joinville e Itajai, tiveram a dificuldade de conseguir agenda, porém depois de muita insistência consegui agendar e realizei em uma única viagem, saindo de criciúma com destino a Itajaí para entrevista com o reitor da UNIVALLI, e pernoitando em Joinville. Na parte da manhã fiz as entrevistas de Joinville, retornando a Itajai no período da tarde para a entrevista com a associação empresarial.

Ao todo foram rodados aproximados 4.000 mil kilometros em aproximadamente 50 horas de viagem nas estradas catarinenses, durante o segundo semestre de 2016, para a coleta de dados da pesquisa. Durante as viagens tive a oportunidade de conhecer novas pessoas e fazer novas amizades e, sempre tive a companhia de minha esposa e em algumas do meu filho. 


\subsection{CATEGORIAS DE ANÁLISE}

As categorias para análise do desenvolvimento que as ICES contribuem com a região em que atuam tem como base as dimensões propostas por Rolim (2009) quando do cálculo do IIR, conforme a seguir:

1. Dimensão: Contribuição da Pesquisa à Inovação Regional - (Resposta às Demandas e Necessidades Regionais; Condições Estruturais para Promover a Pesquisa e a Inovação; Processos Facilitadores da Transmissão e Aproveitamento do Conhecimento);

2a. Dimensão: Contribuição do Ensino e Aprendizado ao Mercado de Trabalho e à Profissionalização - (Territorialização do Processo de Aprendizagem; Atração de Estudantes e Emprego Regional; Promoção de Educação Contínua, Treinamento e Aperfeiçoamento Profissional; Formas Alternativas de Ensino; Otimização do Sistema Regional de Aprendizagem)

3. Dimensão: Contribuição ao Desenvolvimento Social, Cultural e Ambiental - (Desenvolvimento Social; Desenvolvimento Cultural; Sustentabilidade Ambiental);

4a. Dimensão: Capacitação Para a Cooperação Regional - (Mecanismos para Promover o Envolvimento Universidade-Região; Promoção Conjunta do Diálogo e Iniciativas de Interesse Regional; Avaliação e Mapeamento do Impacto da Universidade; Capacitação Institucional Para o Envolvimento Regional; Gerenciamento dos Recursos Humanos e Financeiros; Criação de uma Nova Cultura Organizacional).

\subsection{JUSTIFICATIVA DA ESCOLHA DOS LOCAIS DE PESQUISA}

A definição das regiões que foram pesquisadas teve como base de análise, além das características citadas, o Índice de Desenvolvimento Econômico Municipal Sustentável (IDEMS), calculado pela Federação 
Catarinense dos Municípios (FECAM), que concentra uma base de indicadores municipais nos seguintes temas: assistência social, demografia, economia, educação, finanças públicas, gestão de risco, saúde, habitação, segurança pública e meio ambiente. Este Índice é uma das ferramentas de indicadores com objetivo de avaliar os municípios segundo seu nível de desenvolvimento sustentável.

O referido índice é composto por 04 dimensões as quais cada uma representa $25 \%$ do total do índice geral, e alguns índices possuem subdimensões com pesos diferentes, conforme se apresenta no quadro 03 .

Quadro 03 - Composição do IDMS

\begin{tabular}{|c|l|c|}
\hline Dimensão & \multicolumn{1}{|c|}{ Subdimensão } & Peso \\
\hline \multirow{3}{*}{ Sociocultural - 25\% } & Educação & $45 \%$ \\
\cline { 2 - 3 } & Saúde & $35 \%$ \\
\cline { 2 - 3 } & Cultura & $10 \%$ \\
\cline { 2 - 3 } & Habitação & $10 \%$ \\
\hline Economica - 25\% & Economia e Renda & $100 \%$ \\
\hline Ambiental - 25\% & Meio Ambiente & $100 \%$ \\
\hline \multirow{3}{*}{ Politico Institucional 25\% } & Participação Social & $30 \%$ \\
\cline { 2 - 3 } & Gestão Publica & $30 \%$ \\
\cline { 2 - 3 } & Finanças & $40 \%$ \\
\hline
\end{tabular}

Fonte: SIDMS/FECAM.

A determinação do IDMS é dada por meio do cálculo da média aritmética dos índices de cada dimensão, e os índices das dimensões são calculados pela média ponderada das sub dimensões, conforme os pesos de cada subdimensão demonstrada no quadro 03; e os índices das subdimensões são calculados pela média aritmética dos indicadores. Assim, a fórmula de cálculo do índice geral é:

$$
\mathrm{IDMS}=\frac{\mathrm{ID}-\mathrm{SC}+\mathrm{ID}-\mathrm{E}+\mathrm{ID}-\mathrm{A}+\mathrm{ID}-\mathrm{PI}}{4}
$$

Onde:

IDMS - Índice de Desenvolvimento Municipal Sustentável

ID-SC - Índice de Desenvolvimento Municipal Sociocultural

ID-E - Índice de Desenvolvimento Municipal Econômico 
ID-A - Índice de Desenvolvimento Municipal Ambiental

ID-PI - Índice de Desenvolvimento Municipal Políticoinstitucional

Os índices e os sub-índices municipais são classificados conforme o quadro 04 a seguir, e na classificação é utilizado indicadores e variáveis, em todos os níveis do sistema, de maneira que se consiga verificar as classificações dos municípios e regiões tanto para o índice geral, quanto para dimensões, subdimensões. No quadro 04, apresentase a classificação do índice conforme o valor do IDMS calculado:

\begin{tabular}{|c|c|}
\hline \multicolumn{2}{|c|}{ Quadro 04 - Classificação do IDMS } \\
\hline Valor do IDMs & Classificação \\
\hline $\begin{array}{c}\text { maior ou igual a } 0,875 \\
\text { maior ou igual a } 0,750 \text { e } \\
\text { men do que } 0,875\end{array}$ & Médio Alto \\
\hline $\begin{array}{c}\text { maior ou igual a } 0,625 e \\
\text { menor do que } 0,750\end{array}$ & Médio \\
\hline $\begin{array}{c}\text { maior ou igual a } 0,500 \text { e } \\
\text { menor do que } 0,625\end{array}$ & Médio Baixo \\
\hline Menro de 0,500 & Baixo \\
\hline
\end{tabular}

Fonte: SIDMS/FECAM (2017a).

A parametrização das variáveis, ou seja, os valores fixados como máximos e mínimos para encaixar os índices dentro das classificações, foram definidos por meio de três métodos:

> Metas, pactos ou valores sugeridos por órgãos de referência nacional ou internacional, como a Organização Mundial de Saúde (OMS), Ministério da Educação, etc.;

$>$ Média do estado ou dos $25 \%$ melhores/ piores;

$>$ Variáveis binárias, que só suportam os índices 0 ou 1 .

No quadro 05, apresenta-se o índice calculado dos municípios que possuem ICES, as quais são representativas nas mesorregiões do estado de Santa Catarina. E verificou-se que os municípios relacionados, possuem índices superiores à média estadual, o que pode ser um 
indicativo da contribuição das universidades comunitárias para o demonstrativo deste índice.

Quadro 05 - Média dos Índices IDMS dos Municípios

\begin{tabular}{|c|l|c|c|c|c|c|}
\hline Ordem & \multicolumn{1}{|c|}{ Municípios } & ID-SC & ID-E & ID-A & ID-PI & IDMS \\
\hline 1 & Itajaí & 0,783 & 0,793 & 0,674 & 0,812 & 0,766 \\
\hline 2 & Joinville & 0,821 & 0,703 & 0,862 & 0,684 & 0,768 \\
\hline 3 & Criciúma & 0,787 & 0,595 & 0,624 & 0,622 & 0,657 \\
\hline 4 & Lages & 0,719 & 0,537 & 0,713 & 0,636 & 0,651 \\
\hline 5 & Chapecó & 0,818 & 0,655 & 0,645 & 0,685 & 0,701 \\
\hline 6 & São Miguel do Oeste & 0,803 & 0,58 & 0,413 & 0,639 & 0,609 \\
\hline & & & & & & \\
\hline & Média Estadual & 0,721 & 0,559 & 0,48 & 0,669 & 0,608 \\
\hline
\end{tabular}

Fonte: SIDMS/FECAM (2017c).

No quadro 06, apresenta-se os índices das messoregiões do estado de Santa Catarina, verificando que das seis messoregiões em que foram divididas o estado, quatro possuem índice acima da média estadual que é 0,608. Ainda consegue-se observar que as regiões localizadas no litoral catarinense são as que possuem o índice maior que a média estadual, com destaque para o vale do Itajaí, com 0,766 , onde encontra a segunda maior ICES em número de alunos.

Quadro 06 - IDEMS das messoregiões de Santa Catarina

\begin{tabular}{|c|l|c|c|c|c|c|}
\hline Ordem & Municípios & ID-SC & ID-E & ID-A & ID-PI & IDMS \\
\hline 1 & Serrana & 0,656 & 0,54 & 0,491 & 0,642 & 0,582 \\
\hline 2 & Oeste Catarinense & 0,726 & 0,571 & 0,388 & 0,684 & 0,592 \\
\hline 3 & Vale do Itajaí & 0,733 & 0,564 & 0,595 & 0,68 & 0,643 \\
\hline 4 & Grande Florianópolis & 0,711 & 0,557 & 0,551 & 0,641 & 0,615 \\
\hline 5 & Norte Catarinense & 0,739 & 0,536 & 0,585 & 0,621 & 0,620 \\
\hline 6 & Sul Catarinense & 0,734 & 0,548 & 0,485 & 0,673 & 0,610 \\
\hline & & & & & & \\
\hline & Média Estadual & 0,721 & 0,559 & 0,48 & 0,669 & 0,608 \\
\hline
\end{tabular}

Fonte: SIDMS/FECAM (2017c).

Os índices apresentados contribuem com a justificativa da escolha das regiões propostas a serem visitadas, tendo em vista demonstrarem que nas regiões que possuem ICES, o IDMS apresenta-se 
acima da média estadual, desta maneira, a pesquisa poderá contribuir em demonstrar possíveis evidências que permitam justificar se a presença das ICES está contribuindo de maneira mais ou menos significativa, para o desenvolvimento regional.

As ações promovidas pelas instituições de ensino nas diversas áreas sociais, culturais, econômicas e as evidências apontadas pelos índices apresentados, corroboram o fato que os municípios onde estão situadas as maiores ICES do estado de santa Catarina, apresentam o IDMS no nível médio e médio alto, índices estes superiores à média estadual. Fato este que pode levar a pensar, que a contribuição das universidades comunitárias, as quais possuem o perfil voltado para a comunidade e sendo propulsoras do desenvolvimento, está contribuindo para o reflexo referente ao crescimento e desenvolvimento regional.

Conforme proposto, foi encaminhado o instrumento para coleta de informações para os dirigentes de seis universidades do Sistema ACAFE, de maneira a conseguir contemplar as mesorregiões do estado e conseguir os dados necessários para as análises propostas nos objetivos desta pesquisa. $\mathrm{O}$ contato com as instituições foi realizado da seguinte maneira:

$\checkmark$ Unoesc - Universidade do Oeste de Santa Catarina;

$\checkmark$ Unochapecó - Universidade Comunitária Regional de Chapecó;

$\checkmark$ Uniplac - Universidade do Planalto Catarinense;

$\checkmark$ Unesc - Universidade do Extremo Sul Catarinense;

$\checkmark$ Univali - Universidade do Vale do Itajaí; e

$\checkmark$ Univille - Universidade da Região de Joinville.

Simultaneamente ao envio do instrumento de coleta de dados, foram agendadas entrevistas no período de setembro a dezembro de 2016, junto às instituições de ensino e às associações empresarias dos municípios sedes das ICES, conforme a seguir:

ACIC - Associação Empresarial de Criciúma;

ACIL - Associação Empresarial de Lages;

ACISMO - Associação Empresarial de São Miguel do Oeste;

ACIC - Associação Empresarial de Chapeco;

ACIJ - Associação Empresarial de Joinville; e

ACII - Associação Empresarial de Itajaí. 
As ICES visitadas estão pertencentes ao sistema ACAFE, localizadas nos municípios, conforme quadro 07, no qual se apresentam algumas características dos municípios, conforme dados da FECAM.

Quadro 07 - Características dos municípios visitados

\begin{tabular}{|l|c|l|c|c|c|c|}
\hline & Criciuma & Chapeco & $\begin{array}{c}\text { São Miguel } \\
\text { do 0este }\end{array}$ & Lages & Itajai & Joinville \\
\hline Associação & AMREC & AMOSC & AMEOSC & AMURES & AMFRI & AMUNESC \\
\hline Secretaria Regional & ADR Criciúma & ADR Chapeco & $\begin{array}{c}\text { ADR São } \\
\text { Miguel do Oeste }\end{array}$ & ADR lages & ADR Itajai & ADR Joinville \\
\hline Area & $236 \mathrm{Km}^{2}$ & $624 \mathrm{Km}^{2}$ & $234 \mathrm{Km}^{2}$ & $2630 \mathrm{Km}^{2}$ & $289 \mathrm{Km}^{2}$ & $1147 \mathrm{Km}^{2}$ \\
\hline População & $209.153,00$ & 209.553 & 39.390 & 158.620 & 208.958 & 569.645 \\
\hline Eleitores & 141.522 & 140.373 & 29.110 & 12.694 & 143.201 & 372.925 \\
\hline PIB & $6.480 .936,04$ & $7.713 .606,57$ & $1.216 .501,54$ & $4.255 .422,22$ & $17.128 .932,09$ & $24.570 .850,78$ \\
\hline
\end{tabular}

Fonte: SIDMS/FECAM (2017a).

A FECAM calcula o IDMS, o qual é a média aritmética dos índices calculados em quatro dimensões, sociocultural, econômica, política e ambiental. Abaixo apresenta-se no quadro 08, a composição destes índices, os quais demonstram a realidade dos municípios visitados, sobre a ótica destas dimensões, as quais podem contribuir a evidenciar os resultados da pesquisa, assim como a contribuição das instituições de ensino para os índices das dimensões estabelecidas pela FECAM. 
Quadro 08 - Indicadores dos municípios visitados

\begin{tabular}{|c|c|c|c|c|c|c|}
\hline & Criciúma & Chapecó & $\begin{array}{c}\text { São } \\
\text { Miguel do } \\
\text { Oeste } \\
\end{array}$ & Lages & Itajai & Joinville \\
\hline SocioCultural & 0,809 & $\mathbf{0 , 8 3 9}$ & 0,812 & 0,767 & 0,798 & 0,850 \\
\hline Educação & $\mathbf{0 , 8 0 4}$ & $\mathbf{0 , 8 2 0}$ & $\mathbf{0 , 8 3 6}$ & 0,657 & 0,754 & 0,836 \\
\hline Acesso e Permanência Escolar & 0,707 & 0,726 & 0,748 & 0,617 & 0,730 & 0,723 \\
\hline Desempenho Escolar & 0,664 & 0,844 & 0,773 & 0,383 & 0,844 & 0,937 \\
\hline Infra estrutura escolar & 0,956 & 0,957 & 0,954 & 0,931 & 0,749 & 0,879 \\
\hline Qualidade no Ensino & 0,890 & 0,754 & 0,870 & 0,696 & 0,692 & 0,805 \\
\hline Saúde & 0,726 & $\mathbf{0 , 7 8 3}$ & 0,744 & 0,730 & 0,799 & 0,754 \\
\hline Cobertura Atenção Basica & 0,602 & 0,793 & 0,891 & 0,917 & 0,773 & 0,421 \\
\hline Fatores de Risco e Proteção & 0,750 & 0,837 & 0,619 & 0,665 & 0,842 & 0,787 \\
\hline Morbidade & 0,757 & 0,673 & 0,646 & 0,627 & 0,820 & 1,000 \\
\hline Mortalidade & 0,793 & 0,827 & 0,818 & 0,709 & 0,759 & 0,809 \\
\hline Cultura & 0,794 & 0,844 & 0,761 & 0,788 & $\mathbf{0 , 8 1 7}$ & 0,900 \\
\hline estrutura de Gestão para Promoção da Cultur & 1,000 & 1,000 & 0,500 & 0,800 & 0,900 & 1,000 \\
\hline Infra estutura Cultural & 1,000 & 1,000 & 0,921 & 1,000 & 1,000 & 1,000 \\
\hline Iniciativas Culturais da Sociedade & 0,936 & 0,936 & 0,837 & 0,936 & 0,837 & 0,936 \\
\hline Recursos da Cultura & 0,241 & 0,441 & 0,786 & 0,416 & 0,530 & 0,665 \\
\hline Habitação & 0,913 & 0,909 & $\mathbf{0 , 9 0 7}$ & $\mathbf{0 , 8 9 3}$ & 0,824 & 0,911 \\
\hline Estutura de gestão para Politicas habitacionai & 1,000 & 1,000 & 1,000 & 1,000 & 1,000 & 1,000 \\
\hline Qualidade habitacional & 0,826 & 0,817 & 0,813 & 0,786 & 0,648 & 0,821 \\
\hline Economica & 0,595 & 0,655 & 0,580 & $\mathbf{0 , 5 3 7}$ & 0,793 & 0,703 \\
\hline Economia & $\mathbf{0 , 5 9 5}$ & 0,655 & $\mathbf{0 , 5 8 0}$ & $\mathbf{0 , 5 3 7}$ & 0,793 & $\mathbf{0 , 7 0 3}$ \\
\hline Agregação do valor Economico & 0,487 & 0,680 & 0,472 & 0,538 & 1,000 & 0,774 \\
\hline Dinamismo economico & 0,632 & 0,645 & 0,646 & 0,564 & 0,665 & 0,633 \\
\hline Nivel de renda & 0,667 & 0,641 & 0,622 & 0,508 & 0,715 & 0,702 \\
\hline Ambiental & 0,624 & 0,645 & 0,413 & 0,713 & 0,674 & 0,862 \\
\hline Meio Ambiente & 0,624 & 0,645 & 0,413 & 0,713 & 0,674 & 0,862 \\
\hline Cobertura saneamento Basico & 0,926 & 0,659 & 0,696 & 0,888 & 0,909 & 0,835 \\
\hline Gestão Ambiental & 0,500 & 0,500 & - & 0,250 & 0,750 & 0,750 \\
\hline Preservação Ambiental & 0,445 & 0,776 & 0,544 & 1,000 & 0,364 & 1,000 \\
\hline Politico Ins titucional & 0,619 & 0,688 & 0,640 & 0,636 & 0,683 & 0,692 \\
\hline Finanças Publicas & 0,637 & 0,661 & 0,627 & 0,631 & 0,658 & 0,612 \\
\hline Saude Financeira & 0,988 & 0,985 & 0,844 & 1,000 & 1,000 & 0,777 \\
\hline Estimulo ao Investimento & 0,182 & 0,202 & 0,383 & 0,300 & 0,974 & 0,254 \\
\hline Capacidade de receita & 0,740 & 0,797 & 0,654 & 0,593 & - & 0,805 \\
\hline Gestão Publica & 0,723 & $\mathbf{0 , 8 9 1}$ & $\mathbf{0 , 8 7 1}$ & 0,819 & 0,943 & 0,956 \\
\hline Articulação com o Exterior & 1,000 & 1,000 & 1,000 & 1,000 & 1,000 & 1,000 \\
\hline Capacidade de planejamento & 0,287 & 0,862 & 0,862 & 0,862 & 1,000 & 0,862 \\
\hline Gestão Financeira & 1,000 & 1,000 & 0,833 & 1,000 & 1,000 & 1,000 \\
\hline Governo Eletronico & 0,500 & 0,833 & 0,667 & 0,250 & 0,750 & 0,917 \\
\hline Qualidade no quadro funcional & 0,829 & 0,761 & 0,994 & 0,981 & 0,965 & 1,000 \\
\hline Participação Social & 0,497 & $\mathbf{0 , 5 1 2}$ & 0,422 & $\mathbf{0 , 4 5 8}$ & 0,449 & $\mathbf{0 , 5 0 8}$ \\
\hline participação Eleitoral & 0,428 & 0,476 & 0,344 & 0,362 & 0,362 & 0,453 \\
\hline Representatividade de generos & 0,565 & 0,547 & 0,500 & 0,554 & 0,536 & 0,563 \\
\hline
\end{tabular}

Fonte: SIDMS/FECAM (2017a) 
A classificação das dimensões estipuladas pela FECAM está distribuída pelo nível alto, médio alto, médio, médio baixo e baixo, e verifica-se que na dimensão sócio cultural todos os municípios visitados estão classificados no nível médio alto. Nesta dimensão de análise da FECAM encontram-se subdimensões em que podem ter influências das atividades desenvolvidas pela IES. 


\section{APRESENTAÇÃO DOS DADOS}

Para o cálculo do IIR das Instituições foram coletadas as informações junto às seis Universidades na Planilha de Coleta de Informações (anexo C), contemplando os dados proposto no modelo de Rolim (2009).

No quadro 09, apresenta-se o IIR das ICES visitadas para entrevista com os gestores:

Quadro 09 - Índice calculado das ICES do Sistema ACAFE

\begin{tabular}{|c|c|c|c|c|c|c|}
\hline Periodo & UNOESC & UNOCHAPECO & UNPPAC & UNESC & UNIVALI & UNIVILIE \\
\hline 2011 & 0,13 & 0,71 & 0,51 & 0,55 & 0,46 & 0,54 \\
\hline 2012 & 0,13 & 0,71 & 0,51 & 0,53 & 0,58 & 0,54 \\
\hline 2013 & 0,38 & 0,76 & 0,53 & 0,60 & 0,58 & 0,51 \\
\hline 2014 & 0,39 & 0,77 & 0,51 & 0,66 & 0,56 & 0,51 \\
\hline 2015 & 0,39 & 0,71 & 0,50 & 0,63 & 0,59 & 0,51 \\
\hline
\end{tabular}

Fonte: Dados da pesquisa.

Com base nos índices demonstrados no quadro 09, percebe-se que a universidade que apresenta maior IRR, segundo a metodologia aplicada, foi a UNOCHAPECÓ, seguida da UNESC e UNIVALI. Entre as universidades visitadas em que foi calculado o IRR, a maioria estão acima 0,50. Em virtude de apenas uma instituição apresentar informações sobre a dimensão 03 , que trata dos cursos de extensão a distância, esta informação não foi considerada para o cálculo do Índice. Dessa maneira, percebe-se que em 2015, os índices calculados variaram entre 0,39 para o menor índice e 0,71 para o maior índice, resultando num índice médio de 0,56.

O gráfico representado na figura 08 apresenta a distribuição dos índices das instituições em relação à média calculada. 
Figura 08 - Distribuição dos índices em relação à Média Calculada

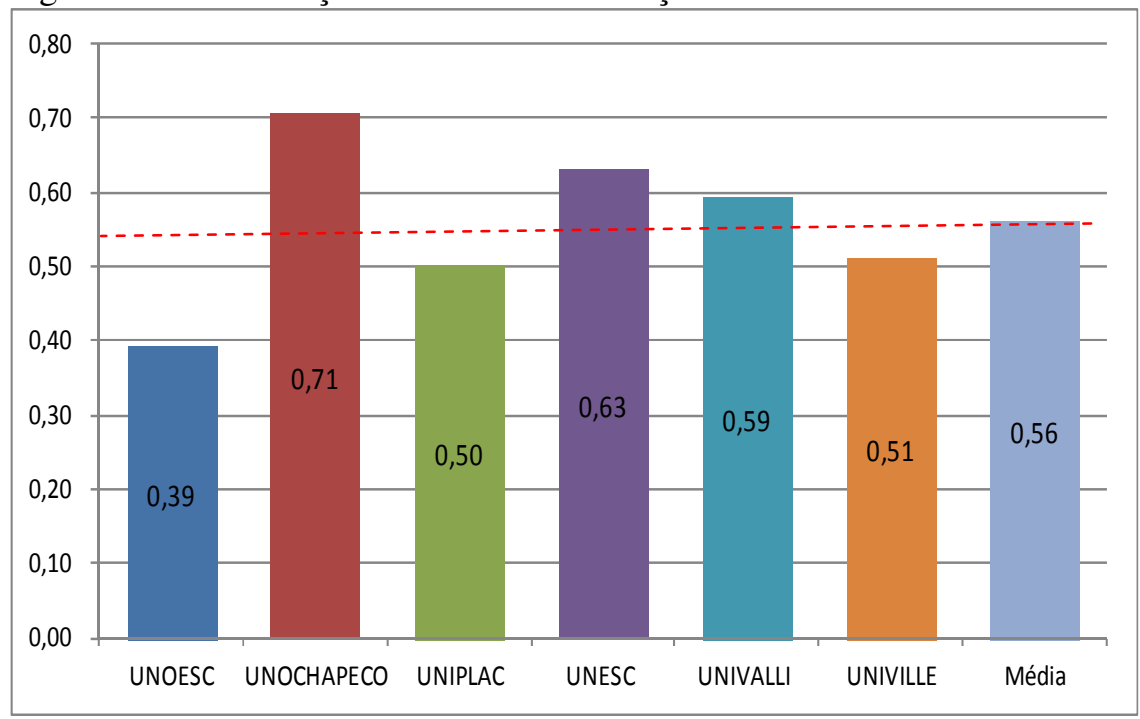

Fonte: Dados da pesquisa

Analisando os índices com base na média aritmética calculada de 0,56, verifica-se, que três universidades apresentam índices acima da média. E estes índices respaldam as informações coletadas nas entrevistas realizadas com os gestores das instituições e com os representantes das associações empresariais dos municípios sedes das instituições de ensino.

\subsection{ANÁLISE DAS ENTREVISTAS}

Com base nas entrevistas, percebe-se que as características apontadas vão ao encontro das características destacadas no capítulo 02 da dissertação, percebendo que as atividades de extensão promovidas pelas ICES são as formas mais evidentes de interação entre a comunidade e a universidade.

Nas entrevistas realizadas nas universidades e nas associações empresarias, as falas foram unânimes quando ressaltaram a importância da universidade para o desenvolvimento local, contribuindo com a formação de mão de obra para a região, promovendo o empreendedorismo local, assim como contribuem com a formação de profissionais qualificados. 
As associações empresariais apontam que uma das principais atividades promovidas pelas instituições de ensino é o assistencialismo que muitas vezes substituem o papel do Estado. Porém, as instituições não se veem reconhecidas pelo governo pelas atividades prestadas à comunidade.

Por outro lado, as associações empresariais afirmam que as instituições de ensino poderiam procurar maior interação com a comunidade empresarial para pensarem juntos a promoção do desenvolvimento e o crescimento regional.

Considerando as categorias de análise de Rolim (2009), pode se dizer que:

1a . Dimensão: Contribuição da Pesquisa à Inovação Regional (Resposta às Demandas e Necessidades Regionais; Condições Estruturais para Promover a Pesquisa e a Inovação; Processos Facilitadores da Transmissão e Aproveitamento do Conhecimento)

Nas entrevistas com a universidades, afirmam que contribuem para a pesquisa de inovação e para a promoção do desenvolvimento. E da mesma forma como as associações empresariais, as ICES afirmaram que os processos de relacionamentos com as entidades, ainda está muito distante. Alguns destacaram que existe um "divórcio" entre a academia e a classe empresarial e outros afirmam que a relação é muito tímida. De maneira geral todos mencionaram que é de extrema importância que esta aproximação aconteça mais rápido possível, pois por serem instituições que pensam no desenvolvimento regional, precisam conversar e estreitar o relacionamento. Conforme mencionado nas entrevistas, "se não o fizerem por vontade própria, serão obrigadas a fazer pela dor e pela necessidade".

Nos quadros a seguir demonstra-se um resumo das percepções encontradas nas entrevistas, com base nas categorias propostas por Rolim (2009). Serão descritos os indicadores apontadas igualmente pelas seis universidades. 
Quadro 10 - Categoria 01- Contribuição da Pesquisa a Inovação Regional

(Continua)

\begin{tabular}{|c|c|c|c|c|c|c|c|c|c|}
\hline है & $\begin{array}{c}\text { Evidências nas } \\
\text { Instituições de Ensino }\end{array}$ & 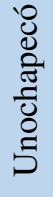 & 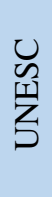 & 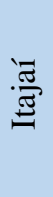 & $\stackrel{\stackrel{0}{\Xi}}{\stackrel{\Xi}{\Xi}}$ & 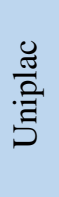 & 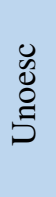 & 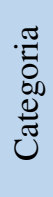 & 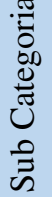 \\
\hline 1 & $\begin{array}{l}\text { Tem como diferencial o } \\
\text { relacionamento com a } \\
\text { comunidade por meio } \\
\text { da atuação }\end{array}$ & $\mathrm{x}$ & $\mathrm{x}$ & $\mathrm{X}$ & & & $\mathrm{x}$ & 1 & 1 \\
\hline 2 & $\begin{array}{lr}\text { Agente } & \text { de } \\
\text { desenvolvimento } & \\
\text { regional, sendo } \\
\text { referência para o } \\
\text { desenvolvimento da } \\
\text { região }\end{array}$ & $\mathrm{x}$ & $\mathrm{X}$ & $\mathrm{X}$ & $\mathrm{X}$ & $\mathrm{x}$ & $\mathrm{x}$ & 1 & 1 \\
\hline 3 & 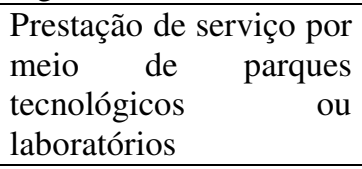 & $\mathrm{X}$ & $\mathrm{X}$ & $\mathrm{x}$ & $\mathrm{x}$ & $\mathrm{x}$ & X & 1 & 2 \\
\hline 4 & $\begin{array}{l}\text { O modelo } \quad \text { de } \\
\text { governança integra a } \\
\text { tríplice hélice }\end{array}$ & $\mathrm{x}$ & & & & & & 1 & 3 \\
\hline 5 & $\begin{array}{lr}\text { O município } & \text { tem a } \\
\text { instituição } & \text { como } \\
\text { parceira } & \\
\end{array}$ & $\mathrm{x}$ & $\mathrm{X}$ & $\mathrm{X}$ & $\mathrm{X}$ & $\mathrm{x}$ & $\mathrm{X}$ & 1 & 1 \\
\hline 6 & $\begin{array}{l}\text { Projetos de extensão } \\
\text { atacam problemas locais } \\
\text { e regionais e tentam } \\
\text { resolver }\end{array}$ & $\mathrm{X}$ & $\mathrm{X}$ & $\mathrm{X}$ & $\mathrm{X}$ & $\mathrm{x}$ & $\mathrm{X}$ & 1 & 1 \\
\hline 7 & $\begin{array}{lr}\text { A atuação } & \text { como } \\
\text { universidade } & \\
\text { comunitária } & \\
\text { corresponde } & \text { à } \\
\text { expectativa } & \text { da } \\
\text { sociedade } & \end{array}$ & $\mathrm{x}$ & $\mathrm{X}$ & $\mathrm{X}$ & $\mathrm{X}$ & & $\mathrm{X}$ & 1 & 1 \\
\hline
\end{tabular}


Quadro 10 - Categoria 01- Contribuição da Pesquisa a Inovação Regional

(Conclusão)

\begin{tabular}{|c|c|c|c|c|c|c|c|c|c|}
\hline 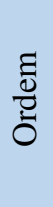 & $\begin{array}{c}\text { Evidências nas } \\
\text { Instituições de Ensino }\end{array}$ & 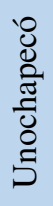 & 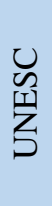 & 菉 & $\stackrel{\stackrel{\bullet}{ٍ:}}{:}$ & $\frac{\mathscr{\pi}}{\frac{\pi}{2}}$ & 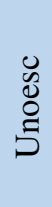 & 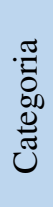 & 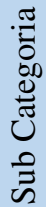 \\
\hline 8 & $\begin{array}{l}\text { Construção do parque } \\
\text { científico e tecnológico }\end{array}$ & $\mathrm{x}$ & $\mathrm{x}$ & $\mathrm{x}$ & $\mathrm{x}$ & & $\mathrm{x}$ & 1 & 2 \\
\hline 9 & $\begin{array}{l}\text { Possuem depósitos de } \\
\text { patentes }\end{array}$ & $\mathrm{X}$ & $\mathrm{x}$ & & & & & 1 & 2 \\
\hline 10 & $\begin{array}{lr}\text { Possuem } & \text { núcleo } \\
\text { inovação } & \text { tecnológica } \\
\text { NIT } & \\
\end{array}$ & $\mathrm{X}$ & $\mathrm{X}$ & & $\mathrm{X}$ & & & 1 & 2 \\
\hline 11 & Projetos de P\&D & & $\mathrm{x}$ & & & & & 1 & 1 \\
\hline 12 & $\begin{array}{l}\text { Possuem núcleo de } \\
\text { empreendedorismo }\end{array}$ & & $\mathrm{X}$ & & $\mathrm{X}$ & & & 1 & 2 \\
\hline 13 & $\begin{array}{ll}\text { Pesquisa } & \text { com } \\
\text { reconhecimento } & \\
\text { internacional } & \\
\end{array}$ & & $\mathrm{X}$ & & & & & 1 & 3 \\
\hline 14 & Possuem incubadoras & $\mathrm{x}$ & $\mathrm{x}$ & $x$ & $\mathrm{x}$ & $\mathrm{x}$ & $\mathrm{x}$ & 1 & 2 \\
\hline 15 & $\begin{array}{l}\mathrm{Na} \text { pesquisa está } \\
\text { envolvida em resolver } \\
\text { questões que tem } \\
\text { impacto na sociedade } \\
\text { local }\end{array}$ & $\mathrm{X}$ & $\mathrm{X}$ & $\mathrm{X}$ & $\mathrm{X}$ & $\mathrm{X}$ & $\mathrm{X}$ & 1 & 1 \\
\hline 16 & $\begin{array}{lr}\text { As ações da Instituição } \\
\text { influenciam } & \text { nas } \\
\text { decisões } & \text { da } \\
\text { comunidade } & \\
\end{array}$ & $\mathrm{X}$ & $\mathrm{X}$ & X & $\mathrm{x}$ & & $\mathrm{x}$ & 1 & 1 \\
\hline
\end{tabular}

Fonte: dados da pesquisa 
Para as instituições de ensino a contribuição da pesquisa a inovação regional ocorre como agente de desenvolvimento regional, sendo referência para o desenvolvimento da região; quando prestam serviço por meio de parques tecnológicos ou laboratórios; quando o município tem a instituição como parceira; quando projetos de extensão atacam problemas locais e regionais e tentam resolver; quando possuem incubadoras; e a pesquisa está envolvida em resolver questões que tem impacto na sociedade local.

Quadro 10.1 - Categoria 01- Contribuição da Pesquisa a Inovação Regional

(Continua)

\begin{tabular}{|c|c|c|c|c|c|c|c|c|c|}
\hline$\frac{\Xi}{0}$ & $\begin{array}{l}\text { Evidências } \\
\text { associações } \\
\text { empresariais }\end{array}$ & 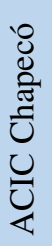 & 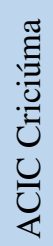 & 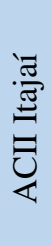 & 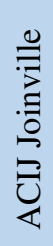 & 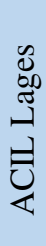 & 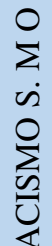 & 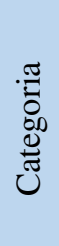 & 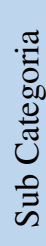 \\
\hline 1 & $\begin{array}{lr}\text { Prestação de } & \text { serviço } \\
\text { ainda deixa a } & \text { desejar } \\
\text { devido } & \text { ao } \\
\text { distanciamento com o } \\
\text { setor produtivo }\end{array}$ & & $\mathrm{x}$ & & $\mathrm{x}$ & $\mathrm{X}$ & $\mathrm{x}$ & 1 & 1 \\
\hline 2 & $\begin{array}{l}\text { As atividades da } \\
\text { universidade } \\
\text { contemplam em parte, } \\
\text { o segmento } \\
\text { empresarial }\end{array}$ & & $\mathrm{x}$ & & $\mathrm{x}$ & & $\mathrm{x}$ & 1 & 3 \\
\hline 3 & $\begin{array}{l}\text { Tem conhecimento que } \\
\text { na universidade } \\
\text { existem projetos de P\& } \\
\text { D }\end{array}$ & & $\mathrm{X}$ & & & & & 1 & 2 \\
\hline 4 & $\begin{array}{l}\text { Talvez com os parques } \\
\text { tecnológicos } \\
\text { momeja } \\
\text { aproximação }\end{array}$ & & $\mathrm{X}$ & & & & & 1 & 1 \\
\hline
\end{tabular}


Quadro 10.1 - Categoria 01- Contribuição da Pesquisa a Inovação Regional

(Conclusão)

\begin{tabular}{|c|c|c|c|c|c|c|c|c|c|}
\hline 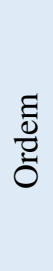 & $\begin{array}{l}\text { Evidências } \\
\text { associações } \\
\text { empresariais }\end{array}$ & 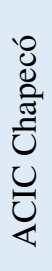 & 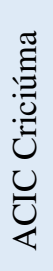 & 第 & 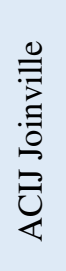 & 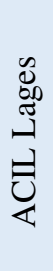 & $\begin{array}{l}0 \\
\sum \\
\dot{2} \\
0 \\
\sum_{0}^{0} \\
0 \\
\end{array}$ & 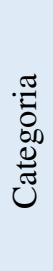 & 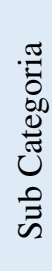 \\
\hline 5 & $\begin{array}{l}\text { Falta de mobilização da } \\
\text { universidade para } \\
\text { divulgar os resultados } \\
\text { de pesquisas }\end{array}$ & & & & & $\mathrm{X}$ & & 1 & 3 \\
\hline 6 & $\begin{array}{l}\text { Falta o Link da } \\
\text { universidade como } \\
\text { empreendedor, a } \\
\text { universidade precisa } \\
\text { fomentar a visão do } \\
\text { empreendedorismo aos } \\
\text { professores e alunos }\end{array}$ & & & & & $\mathrm{X}$ & & 1 & 3 \\
\hline 7 & $\begin{array}{l}\text { A universidade é um } \\
\text { vetor } \\
\text { desenvolvimento, mas } \\
\text { não é o canal do } \\
\text { desenvolvimento }\end{array}$ & & & & & $\mathrm{x}$ & & 1 & 1 \\
\hline 8 & $\begin{array}{l}\text { Universidade pesquisa } \\
\text { mais para ela, para } \\
\text { publicação, tem que } \\
\text { continuar fazendo isso, } \\
\text { mas vai ter que abrir } \\
\text { uma área de pesquisa } \\
\text { Empresarial }\end{array}$ & & $\mathrm{X}$ & & & $\mathrm{X}$ & & 1 & 2 \\
\hline 9 & $\begin{array}{l}\text { A produção científica } \\
\text { deveria ter outro viés, } \\
\text { além apenas da } \\
\text { publicação, deveria o } \\
\text { aluno saber o que } \\
\text { aquele objeto de estudo } \\
\text { reverte para a } \\
\text { sociedade }\end{array}$ & & & & & $\mathrm{x}$ & & 1 & 1 \\
\hline
\end{tabular}

Fonte: dados da pesquisa 
$\mathrm{Na}$ percepção das associações empresariais a contribuição da pesquisa a inovação regional ainda é falha, porque a prestação de serviço ainda deixa a desejar devido ao distanciamento com o setor produtivo e as atividades da universidade contemplam em parte o segmento empresarial.

Quadro 10.2 - Análise da Categoria 01- Contribuição da Pesquisa a Inovação Regional

\begin{tabular}{|c|l|c|c|c|c|}
\hline \multirow{2}{*}{ Ordem } & \multicolumn{2}{|c|}{ Subcategorias } & \multicolumn{2}{|c|}{ ICES } & \multicolumn{2}{c|}{ ACICs } \\
\cline { 3 - 6 } & & Quant. & $\%$ & Quant. & $\%$ \\
\hline 1 & $\begin{array}{l}\text { Resposta às demandas e } \\
\text { necessidades regionais }\end{array}$ & 08 & $50 \%$ & 4 & $44,44 \%$ \\
\hline 2 & $\begin{array}{l}\text { Condições estruturais para } \\
\text { promover a pesquisa e a } \\
\text { inovação }\end{array}$ & 06 & $38 \%$ & 2 & $22,22 \%$ \\
\hline 3 & $\begin{array}{l}\text { Processos facilitadores da } \\
\text { transmissão } \\
\text { aproveitamento } \\
\text { conhecimento }\end{array}$ & 02 & $12 \%$ & 3 & $33,33 \%$ \\
\hline \multicolumn{2}{|c|}{ Total } & $\mathbf{1 6}$ & $\mathbf{1 0 0 \%}$ & $\mathbf{9}$ & $\mathbf{1 0 0 \%}$ \\
\hline
\end{tabular}

Fonte: dados da pesquisa

Em síntese os resultados apontam na categoria de análise 01, dezesseis subcategorias por parte das ICES e nove subcategorias pelas ACICs, destacando que as associações empresarias apontaram para as necessidades de melhorar o relacionamentos entre as partes para que consigam corresponder com as propostas das subcategorias. Enquanto as instituições mencionam que correspondem com as expectativas para contribuição do desenvolvimento regional. Contudo, as associações empresariais destacam o distanciamento das universidades chegando-se a afirmar que existe um divórcio entre as duas entidades. Umas das associações empresariais entrevistada afirma que "este vácuo de espaço, este guep que existe entre os dois mundos, é que precisa avançar, a universidade é uma fonte de pesquisa e se você partir para a vala comum não se chega a lugar nenhum, tem que ser ousado e ousar é investir em pesquisa." 
2a . Dimensão: Contribuição do Ensino e Aprendizado ao Mercado de Trabalho e à Profissionalização - (Territorialização do Processo de Aprendizagem; Atração de Estudantes e Emprego Regional; Promoção de Educação Contínua, Treinamento e Aperfeiçoamento Profissional; Formas Alternativas de Ensino; Otimização do Sistema Regional de Aprendizagem)

As entrevistas nas ICES e nas associações empresariais, mostram que as atividades promovidas pelas universidades contribuem com a aprendizagem dos profissionais para o mercado de trabalho e para a profissionalização da mão de obra regional. As ICES conseguem atrair jovens de municípios vizinhos até o município onde se encontra a universidade, contribuindo dessa forma para o desenvolvimento desses municípios.

Ainda, contribuem com o movimento econômico local, atraindo estudantes que devido à distância, vem residir e trabalhar no município sede das ICES durante o período em que estão em formação, sendo potenciais estagiários ou empregados qualificados contribuindo para o desenvolvimento econômico das empresas locais.

As entrevistas também destacaram que as universidades comunitárias conseguem desempenhar o seu papel de formação de mão de obra qualificada, fato que é percebido e reconhecido tanto pelos gestores das instituições de ensino como pelas associações empresariais.

Quadro 11 - Categoria 02 - Contribuição do Ensino e Aprendizado ao Mercado de Trabalho e à Profissionalização

(Continua)

\begin{tabular}{|c|c|c|c|c|c|c|c|c|c|}
\hline 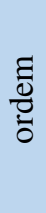 & $\begin{array}{l}\text { Evidências nas } \\
\text { Instituições de } \\
\text { Ensino }\end{array}$ & 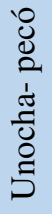 & 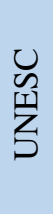 & 点 & & 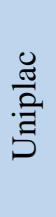 & 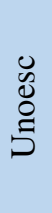 & 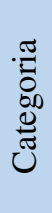 & 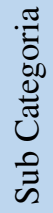 \\
\hline 1 & $\begin{array}{lr}\text { Existência } & \text { da } \\
\text { proximidade com } & \mathrm{o} \\
\text { setor produtivo } & \\
\end{array}$ & $\mathrm{x}$ & & $\mathrm{X}$ & $\mathrm{X}$ & & $\mathrm{x}$ & 2 & 2 \\
\hline 2 & $\begin{array}{l}\text { Mantêm o } \\
\text { relacionamento com a } \\
\text { comunidade por meio } \\
\text { dos cursos de extensão } \\
\text { e prestação de serviços }\end{array}$ & $\mathrm{X}$ & $\mathrm{X}$ & $\mathrm{X}$ & $\mathrm{X}$ & $\mathrm{X}$ & $\mathrm{x}$ & 2 & 3 \\
\hline
\end{tabular}


Quadro 11 - Categoria 02 - Contribuição do Ensino e Aprendizado ao Mercado de Trabalho e à Profissionalização

(Conclusão)

\begin{tabular}{|c|c|c|c|c|c|c|c|c|c|}
\hline$\frac{\tilde{D}}{0}$ & $\begin{array}{l}\text { Evidências nas } \\
\text { Instituições de } \\
\text { Ensino }\end{array}$ & 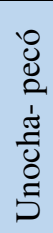 & 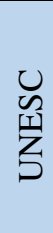 & 胥 & $\stackrel{\stackrel{0}{ٍ: ~}}{:}$ & 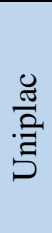 & $\begin{array}{l}\text { Uू } \\
\text { ठ } \\
\vdots\end{array}$ & 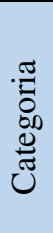 & 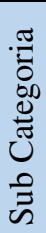 \\
\hline 3 & $\begin{array}{lr}\text { Proporciona } & \text { a } \\
\text { formação nas } & \text { diversas } \\
\text { áreas com cursos } \\
\text { específicos }\end{array}$ & $\mathrm{x}$ & $\mathrm{X}$ & $\mathrm{x}$ & $\mathrm{x}$ & & & 2 & 1 \\
\hline 4 & $\begin{array}{lr}\text { Cursos de } & \text { graduação } \\
\text { voltados } & \text { para } \\
\text { atividades } & \text { econômicas } \\
\text { regionais } & \end{array}$ & & & $\mathrm{x}$ & $\mathrm{x}$ & $\mathrm{x}$ & & 2 & 1 \\
\hline
\end{tabular}

Fonte: dados da pesquisa

Para as instituições de ensino, a contribuição do ensino e aprendizado ao mercado de trabalho e à profissionalização ocorre quando mantêm o relacionamento com a comunidade por meio dos cursos de extensão e prestação de serviços.

Quadro 11.1 - Categoria 02 - Contribuição do Ensino e Aprendizado ao Mercado de Trabalho e à Profissionalização

(Continua)

\begin{tabular}{|c|c|c|c|c|c|c|c|c|c|}
\hline है & $\begin{array}{lr}\text { Evidências } & \text { nas } \\
\text { associações empresariais }\end{array}$ & 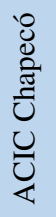 & 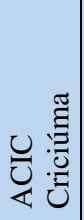 & 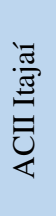 & 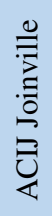 & 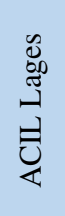 & 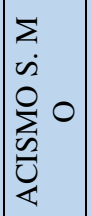 & 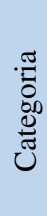 & 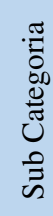 \\
\hline 1 & $\begin{array}{lr}\text { Precisa } & \text { revisar } \\
\text { currículos escolares de } \\
\text { maneira a continuar } \\
\text { sendo geradora de mão } \\
\text { de obra qualificada }\end{array}$ & & $\mathrm{X}$ & & & & & 2 & 3 \\
\hline 2 & $\begin{array}{l}\text { A Instituição ajuda o } \\
\text { setor produtivo com } \\
\text { cursos e atividades de } \\
\text { extensão }\end{array}$ & & $\mathrm{X}$ & $\mathrm{X}$ & & & & 2 & 3 \\
\hline
\end{tabular}


Quadro 11.1 - Categoria 02 - Contribuição do Ensino e Aprendizado ao Mercado de Trabalho e à Profissionalização

(Conclusão)

\begin{tabular}{|c|c|c|c|c|c|c|c|c|c|}
\hline$\frac{\tilde{D}}{\overline{0}}$ & $\begin{array}{l}\text { Evidências } \\
\text { associações } \\
\text { empresariais }\end{array}$ & 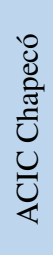 & 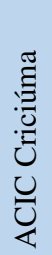 & 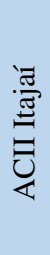 & 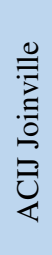 & 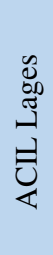 & 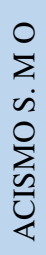 & 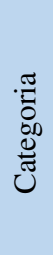 & 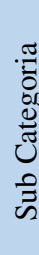 \\
\hline 3 & $\begin{array}{l}\text { A Universidade } \\
\text { promove a formação e } \\
\text { capacitação de } \\
\text { profissionais que ficam } \\
\text { no município e região }\end{array}$ & & & $\mathrm{X}$ & & $\mathrm{x}$ & $\mathrm{X}$ & 2 & 3 \\
\hline 4 & $\begin{array}{l}\text { Possui programas de } \\
\text { formação para as } \\
\text { atividades econômicas } \\
\text { locais e regionais }\end{array}$ & & & $\mathrm{X}$ & & & & 2 & 5 \\
\hline
\end{tabular}

Fonte: dados da pesquisa

Para as associações empresariais as respostas que venham a contribuir para o ensino e aprendizado ao mercado de trabalho e à profissionalização não foi relevante, visto que somente 3 associações empresariais apontaram que a Universidade promove a formação e capacitação de profissionais que ficam no município e região.

Quadro 12 - Análise da Categoria 03 - Contribuição do Ensino e Aprendizado ao Mercado de Trabalho e à Profissionalização

(Continua)

\begin{tabular}{|c|lr|c|c|c|c|}
\hline \multirow{2}{*}{ Ordem } & \multicolumn{2}{|c|}{ Subcategorias } & \multicolumn{2}{c|}{ ICES } & \multicolumn{2}{c|}{ ACICs } \\
\cline { 3 - 6 } & Quant. & $\%$ & Quant. & $\%$ \\
\hline 1 & $\begin{array}{l}\text { Territorialização } \\
\text { processo } \\
\text { aprendizagem }\end{array}$ & $\begin{array}{l}\text { do } \\
\text { de }\end{array}$ & 2 & $50 \%$ & 0 & $0 \%$ \\
\hline 2 & $\begin{array}{l}\text { Atração de estudantes e } \\
\text { emprego regional }\end{array}$ & 1 & $25 \%$ & 0 & $0 \%$ \\
\hline
\end{tabular}


Quadro 12 - Análise da Categoria 03 - Contribuição do Ensino e Aprendizado ao Mercado de Trabalho e à Profissionalização

(Conclusão)

\begin{tabular}{|c|l|c|c|c|c|}
\hline \multirow{2}{*}{ Ordem } & \multirow{2}{*}{ Subcategorias } & \multicolumn{2}{|c|}{ ICES } & \multicolumn{2}{|c|}{ ACICs } \\
\cline { 2 - 6 } 3 & Quant. & $\%$ & Quant. & $\%$ \\
\hline 3 & $\begin{array}{l}\text { Promoção de } \\
\text { educação } \\
\text { contínua, } \\
\text { treinamento e } \\
\text { aperfeiçoamento } \\
\text { profissional }\end{array}$ & 1 & $25 \%$ & 3 & $75 \%$ \\
\hline 4 & $\begin{array}{l}\text { Formas } \\
\text { alternativas de } \\
\text { ensino }\end{array}$ & 0 & $0 \%$ & 0 & 0 \\
\hline 5 & $\begin{array}{l}\text { Otimização do } \\
\text { sistema regional } \\
\text { de aprendizagem }\end{array}$ & 0 & $0 \%$ & 1 & $25 \%$ \\
\hline \multicolumn{1}{|c|}{ Total } & $\mathbf{0 4}$ & $\mathbf{1 0 0 \%}$ & $\mathbf{5}$ & $\mathbf{1 0 0 \%}$ \\
\hline
\end{tabular}

Fonte: dados da pesquisa

Nessa dimensão foram pontuadas algumas evidências destacadas nas entrevistas, percebe-se que as instituições de ensino contribuem com o desenvolvimento da região por meio da oferta de cursos voltados para a região, como destacada na entrevista da UNIVALLI, quando menciona que possui cursos voltados para a área portuária.

Nessa dimensão, destaca-se poucas evidencias da contribuição das ICEs para o ensino e aprendizagem, pois, foi apresentado críticas quanto a necessidade de cursos voltados para as características regionais, que contribuam com a demanda de mão de obra local, e assim contribuírem com as empresas regionais.

\section{3a. Dimensão: Contribuição ao Desenvolvimento Social, Cultural e Ambiental - (Desenvolvimento Social; Desenvolvimento Cultural; Sustentabilidade Ambiental)}

Em todas as entrevistas ficou evidenciado que as ICES contribuem significativamente para o desenvolvimento social, cultural e ambiental, e em algumas regiões, as atividades culturais acontece especialmente devido às ações promovidas pelas ICES. Muitas das atividades culturais já constam nos calendários locais dos municípios, 
sendo este um dos diferenciais apontados pelas associações empresariais. Com relação ao desenvolvimento social, foi destacado tanto pelas associações empresariais como pelas universidades, as ações promovidas pelas atividades de extensão na área assistencial na área da saúde e jurídica, tanto nos bairros como nos atendimentos nas próprias instituições.

Quanto à sustentabilidade ambiental, algumas das universidades são destaque nesta atividade por meio de projetos institucionais e projetos fomentados com recursos de empresas públicas. Algumas são reconhecidos pelas associações empresariais como destaque positivo das instituições de ensino.

Quadro 13 - Categoria 03 - Contribuição ao Desenvolvimento Social, Cultural e Ambiental

\begin{tabular}{|c|c|c|c|c|c|c|c|c|c|}
\hline$\frac{\tilde{0}}{0}$ & $\begin{array}{l}\text { Evidências nas } \\
\text { Instituições de Ensino }\end{array}$ & 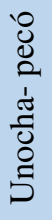 & $\begin{array}{l}\text { U } \\
\text { Î̀ } \\
\text { Z }\end{array}$ & 菉 & 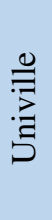 & 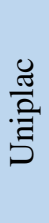 & 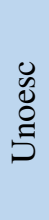 & . & 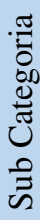 \\
\hline 1 & $\begin{array}{l}\text { Atuação nas áreas do } \\
\text { esporte, cultura, e na } \\
\text { parte de assistencialismos } \\
\text { nas áreas da saúde e } \\
\text { Jurídica }\end{array}$ & $\mathrm{X}$ & $\mathrm{x}$ & $\mathrm{x}$ & $\mathrm{x}$ & $\mathrm{x}$ & $\mathrm{X}$ & 3 & $\begin{array}{c}1 \mathrm{e} \\
2\end{array}$ \\
\hline 2 & $\begin{array}{lr}\text { Prestação de } & \text { serviço, por } \\
\text { meio de } & \text { parques } \\
\text { tecnológicos } & \text { ou } \\
\text { laboratórios } & \end{array}$ & $\mathrm{x}$ & $\mathrm{x}$ & $\mathrm{x}$ & $\mathrm{x}$ & $\mathrm{x}$ & $\mathrm{X}$ & 3 & 3 \\
\hline 3 & $\begin{array}{l}\text { Relação de consultor } \\
\text { produtivo na relação com } \\
\text { a comunidade }\end{array}$ & $\mathrm{x}$ & & $\mathrm{x}$ & $\mathrm{x}$ & & $\mathrm{x}$ & 3 & 3 \\
\hline 4 & 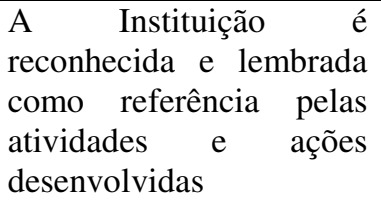 & $\mathrm{x}$ & $\mathrm{x}$ & $\mathrm{x}$ & $\mathrm{x}$ & & & 3 & 1 \\
\hline
\end{tabular}


Quadro 13 - Categoria 03 - Contribuição ao Desenvolvimento Social, Cultural e Ambiental

(Conclusão)

\begin{tabular}{|c|c|c|c|c|c|c|c|c|c|}
\hline$\frac{\Xi}{0}$ & $\begin{array}{l}\text { Evidências nas } \\
\text { Instituições de Ensino }\end{array}$ & 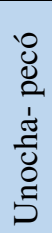 & 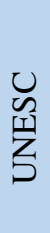 & . & 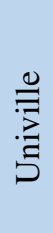 & 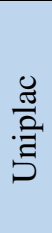 & $\begin{array}{l}\text { Uू } \\
\text { ठ } \\
\vdots\end{array}$ & 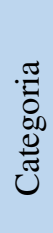 & 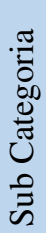 \\
\hline 5 & $\begin{array}{l}\text { Projetos de extensão } \\
\text { atacam problemas locais } \\
\text { e regionais e tentam } \\
\text { resolver }\end{array}$ & $\mathrm{X}$ & $\mathrm{X}$ & $\mathrm{x}$ & $\mathrm{X}$ & $\mathrm{x}$ & $\mathrm{X}$ & 3 & 3 \\
\hline 6 & $\begin{array}{l}\text { Possuem envolvimento } \\
\text { direto com a comunidade }\end{array}$ & $\mathrm{X}$ & $\mathrm{X}$ & $\mathrm{x}$ & $\mathrm{X}$ & $\mathrm{X}$ & $\mathrm{X}$ & 3 & 1 \\
\hline 7 & $\begin{array}{l}\text { Contribui com } \mathrm{o} \\
\text { desenvolvimento } \\
\text { mobiliário }\end{array}$ & & $\mathrm{X}$ & & $\mathrm{X}$ & & & 3 & 1 \\
\hline
\end{tabular}

Fonte: dados da pesquisa

Para as instituições de ensino a contribuição ao desenvolvimento social, cultural e ambiental ocorre durante a atuação nas áreas do esporte, cultura, e na parte de assistencialismos nas áreas da saúde e Jurídica, por meio da prestação de serviço, por meio de parques tecnológicos ou laboratórios; nos projetos de extensão atacam problemas locais e regionais e tentam resolver e quando possuem envolvimento direto com a comunidade. 
Quadro 13.1 - Categoria 03 - Contribuição ao Desenvolvimento Social, Cultural e Ambiental

\begin{tabular}{|c|c|c|c|c|c|c|c|c|c|}
\hline$\frac{\overline{0}}{0}$ & $\begin{array}{l}\text { Evidências nas } \\
\text { Associações } \\
\text { Empresariais }\end{array}$ & 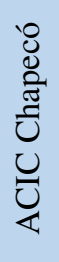 & 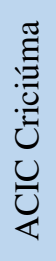 & 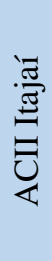 & 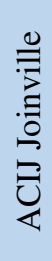 & 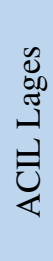 & $\begin{array}{l}0 \\
\sum \\
\dot{\Sigma} \\
0 \\
\sum_{\infty}^{0} \\
0 \\
0\end{array}$ & 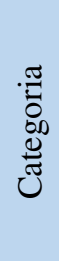 & 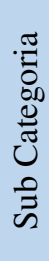 \\
\hline 1 & $\begin{array}{l}\text { A universidade é } \\
\text { conhecida pelas diversas } \\
\text { atividades que } \\
\text { desenvolve }\end{array}$ & $\mathrm{x}$ & $\mathrm{x}$ & $\mathrm{X}$ & $\mathrm{X}$ & & $\mathrm{X}$ & 3 & 1 \\
\hline 2 & $\begin{array}{lr}\text { Conhecem as atividades } \\
\text { assistenciais e culturais } \\
\text { promovidas r pela } \\
\text { Universidade }\end{array}$ & $\mathrm{x}$ & $\mathrm{x}$ & $\mathrm{x}$ & $\mathrm{x}$ & $\mathrm{x}$ & $\mathrm{x}$ & 3 & 1 \\
\hline 3 & $\begin{array}{l}\text { A universidade possui } \\
\text { atividades específicas } \\
\text { para determinadas áreas } \\
\text { voltadas para a } \\
\text { comunidade em geral }\end{array}$ & & & $\mathrm{x}$ & & & $\mathrm{x}$ & 3 & 1 \\
\hline 4 & $\begin{array}{l}\text { A universidade é } \\
\text { voltada ao } \\
\text { assistencialismo, falta o } \\
\text { link no fomento } \\
\text { econômico }\end{array}$ & & & & & $\mathrm{x}$ & & 3 & 1 \\
\hline
\end{tabular}

Fonte: dados da pesquisa

A contribuição ao desenvolvimento social, cultural e ambiental é percebida pelas associações empresariais quando a universidade desenvolve diversas atividades na área e nas atividades assistenciais e culturais promovidas pela universidade. 
Quadro 13.2 - Análise Categoria 03 - Contribuição ao Desenvolvimento Social, Cultural e Ambiental

\begin{tabular}{|c|c|c|c|c|c|}
\hline \multirow{2}{*}{ Ordem } & Subcategorias & \multicolumn{2}{|c|}{ ICES } & \multicolumn{2}{c|}{ ACICs } \\
\hline & & Quant. & $\%$ & Quant. & $\%$ \\
\hline 1 & Desenvolvimento Social & 4 & $50 \%$ & 4 & $100 \%$ \\
\hline 2 & Desenvolvimento Cultural & 1 & $12,5 \%$ & 0 & $0 \%$ \\
\hline 3 & $\begin{array}{c}\text { Sustentabilidade } \\
\text { Ambiental }\end{array}$ & 3 & $37,5 \%$ & 0 & $0 \%$ \\
\hline & Total & $\mathbf{8}$ & $\mathbf{1 0 0 \%}$ & $\mathbf{4}$ & $\mathbf{1 0 0 \%}$ \\
\hline
\end{tabular}

Fonte: dados da pesquisa

Nessa dimensão se destacaram as atividades social, cultural e ambiental promovidas com envolvimento das instituições de ensino dentro do ambiente interno da ICES, principalmente na área da saúde e no esporte, sendo apontado com destaque pela comunidade externa à instituição.

Nas entrevistas ficou evidente a participação das ICES em projetos ambientais, porém, essas atividades são desconhecidas pela comunidade empresarial. Outro ponto que foram destaques nas falas das instituições de ensino, são as atividades culturais e eventos que organizam, inseridos no calendário dos municípios, porém não foram destacados pelas associações empresariais.

4a. Dimensão: Capacitação Para a Cooperação Regional (Mecanismos para Promover o Envolvimento Universidade-Região; Promoção Conjunta do Diálogo e Iniciativas de Interesse Regional; Avaliação e Mapeamento do Impacto da Universidade; Capacitação Institucional Para o Envolvimento Regional; Gerenciamento dos Recursos Humanos e Financeiros; Criação de uma Nova Cultura Organizacional).

Com relação a essa categoria, as entrevistas demonstram a existência de vários mecanismos de extensão ou pesquisa que conseguem promover o envolvimento das universidades com a região, atividades estas que são destacadas por ambas as partes. As falas foram unânimes em todas as universidades e associações, que falta a promoção de um diálogo conjunto entre universidade e associação empresarial que 
busquem pensar juntos em soluções para as demandas regionais. De acordo com as falas dos entrevistados, em alguns municípios essa aproximação já ocorre, porém de maneira tímida, necessitando que o relacionamento seja estreitado para que consigam de maneira concreta pensarem em mudanças estruturais que contribuam com 0 desenvolvimento da região.

Ambos entendem que as regiões possuem o grau de desenvolvimento que tem, em virtude da existência das universidades. Em alguns casos foi destacado que o desenvolvimento do município e da região está no estágio que se encontra devido à universidade. Pensar o município sem a universidade teria que se pensar tudo que deixaria de existir também, ou tudo que aconteceu ou acontece devido às instituições de ensino.

Quadro 14 - Categoria 4 - Capacitação para a Cooperação Regional

(Continua)

\begin{tabular}{|c|c|c|c|c|c|c|c|c|c|}
\hline$\frac{\Xi}{0}$ & $\begin{array}{l}\text { Evidências nas } \\
\text { Instituições de Ensino }\end{array}$ & 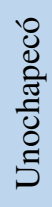 & 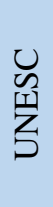 & . & 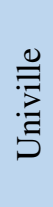 & $\frac{\mathscr{z}}{\frac{\pi}{Z}}$ & 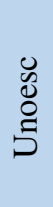 & . & 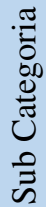 \\
\hline 1 & $\begin{array}{l}\text { Tem como diferencial o } \\
\text { relacionamento com a } \\
\text { comunidade por meio da } \\
\text { atuação }\end{array}$ & $\mathrm{x}$ & $\mathrm{X}$ & $\mathrm{x}$ & & & $\mathrm{x}$ & 4 & 2 \\
\hline 2 & $\begin{array}{lr}\text { Agente } & \text { de } \\
\text { desenvolvimento } & \\
\text { regional, } & \text { sendo } \\
\text { referência para } & \text { o } \\
\text { desenvolvimento } & \text { da } \\
\text { região } & \\
\end{array}$ & $\mathrm{X}$ & $\mathrm{X}$ & $\mathrm{X}$ & $\mathrm{X}$ & $\mathrm{X}$ & $\mathrm{X}$ & 4 & 2 \\
\hline 3 & $\begin{array}{lr}\text { Prestação de } & \text { serviço por } \\
\text { meio de } & \text { parques } \\
\text { tecnológicos } & \text { ou } \\
\text { laboratórios } & \\
\end{array}$ & $\mathrm{X}$ & $\mathrm{X}$ & $\mathrm{X}$ & $\mathrm{x}$ & $\mathrm{X}$ & $\mathrm{X}$ & 4 & 1 \\
\hline 4 & $\begin{array}{l}\text { Relação de consultor } \\
\text { produtivo na relação } \\
\text { com a comunidade }\end{array}$ & $\mathrm{X}$ & & $\mathrm{X}$ & $\mathrm{x}$ & & $\mathrm{X}$ & 4 & 1 \\
\hline
\end{tabular}


Quadro 14 - Categoria 4 - Capacitação para a Cooperação Regional

(Continuação)

\begin{tabular}{|c|c|c|c|c|c|c|c|c|c|}
\hline$\frac{\tilde{0}}{\overline{0}}$ & $\begin{array}{l}\text { Evidências nas } \\
\text { Instituições de Ensino }\end{array}$ & 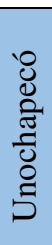 & $\begin{array}{l}U \\
\mathscr{n} \\
\text { Z゙ }\end{array}$ & 凉 & 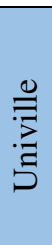 & 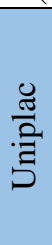 & 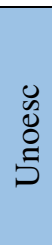 & 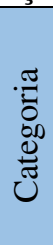 & 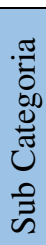 \\
\hline 5 & $\begin{array}{l}\text { Comunidade participa das } \\
\text { decisões da universidade } \\
\text { por meio dos conselhos }\end{array}$ & $\mathrm{x}$ & $\mathrm{x}$ & $\mathrm{x}$ & $\mathrm{X}$ & $\mathrm{X}$ & $\mathrm{x}$ & 4 & 6 \\
\hline 6 & $\begin{array}{l}\text { Existência da proximidade } \\
\text { com o setor produtivo }\end{array}$ & $\mathrm{x}$ & & $\mathrm{x}$ & $\mathrm{x}$ & & $\mathrm{x}$ & 4 & 2 \\
\hline 7 & $\begin{array}{l}\text { Envolvimento com } \\
\text { entidades regionais como } \\
\text { Acic, conselhos e outros } \\
\text { tendo representantes } \\
\text { nestas associações }\end{array}$ & $\mathrm{x}$ & $\mathrm{x}$ & $\mathrm{X}$ & $\mathrm{x}$ & $\mathrm{X}$ & $\mathrm{x}$ & 4 & 4 \\
\hline 8 & $\begin{array}{l}\text { A instituição tenta mostrar } \\
\text { que não tem cor e nem } \\
\text { partido }\end{array}$ & $\mathrm{x}$ & $\mathrm{x}$ & $\mathrm{X}$ & $\mathrm{X}$ & & $\mathrm{x}$ & 4 & 6 \\
\hline 9 & $\begin{array}{l}\text { Existe a relação com o } \\
\text { poder público municipal }\end{array}$ & $\mathrm{X}$ & $\mathrm{x}$ & $\mathrm{X}$ & $\mathrm{x}$ & $\mathrm{X}$ & $\mathrm{x}$ & 4 & 2 \\
\hline 10 & $\begin{array}{l}\text { O município tem a } \\
\text { instituição como parceira; }\end{array}$ & $\mathrm{x}$ & $\mathrm{x}$ & $\mathrm{x}$ & $\mathrm{x}$ & $\mathrm{x}$ & $\mathrm{x}$ & 4 & 2 \\
\hline 11 & $\begin{array}{l}\text { Construção do parque } \\
\text { científico e tecnológico; }\end{array}$ & $\mathrm{x}$ & $\mathrm{x}$ & $\mathrm{X}$ & $\mathrm{X}$ & & $\mathrm{x}$ & 4 & 1 \\
\hline 12 & $\begin{array}{lll}\begin{array}{l}\text { Possuem } \\
\text { patentes }\end{array} & \text { depósitos } & \text { de } \\
\end{array}$ & $\mathrm{X}$ & $\mathrm{x}$ & & & & & 4 & 1 \\
\hline 13 & $\begin{array}{l}\text { Possuem núcleo inovação } \\
\text { tecnológica NIT }\end{array}$ & $\mathrm{X}$ & $\mathrm{x}$ & & $\mathrm{x}$ & & & 4 & 1 \\
\hline 14 & $\begin{array}{l}\text { Possuem envolvimento } \\
\text { direto com a comunidade }\end{array}$ & $\mathrm{X}$ & $\mathrm{x}$ & $\mathrm{X}$ & $\mathrm{x}$ & $\mathrm{X}$ & $\mathrm{x}$ & 4 & 2 \\
\hline
\end{tabular}


Quadro 14 - Categoria 4 - Capacitação para a Cooperação Regional

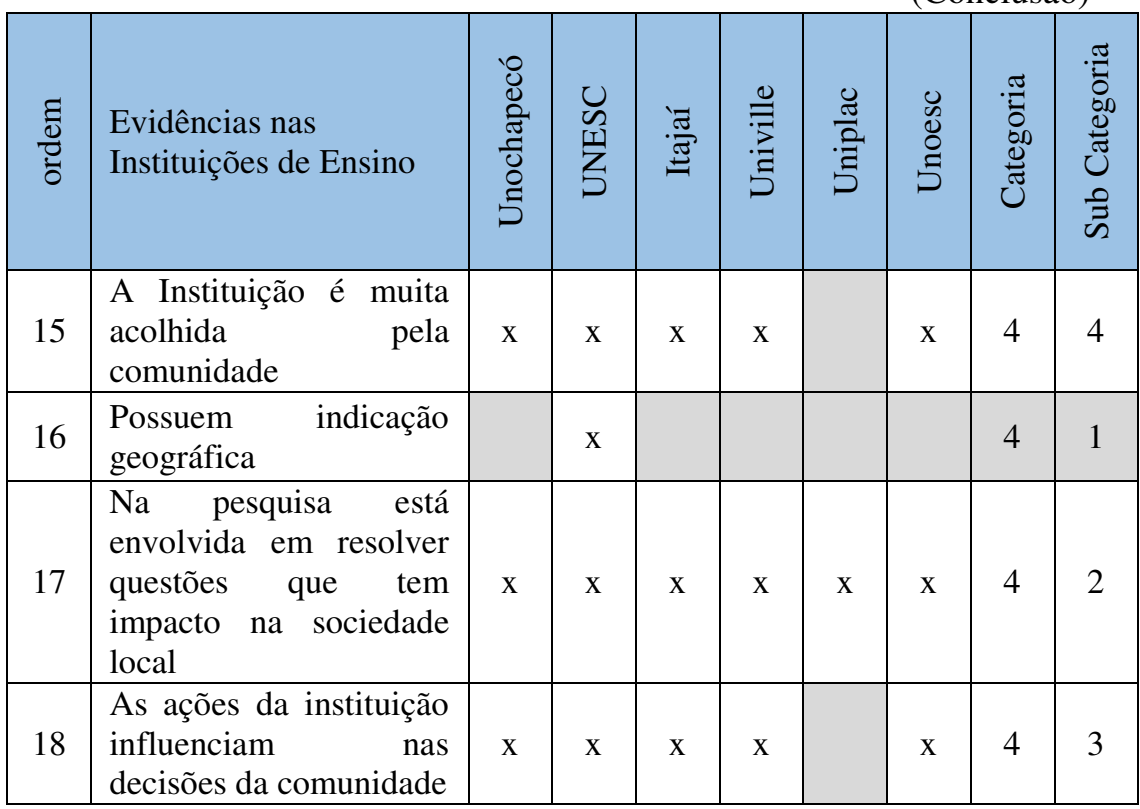

Fonte: dados da pesquisa

As instituições de ensino destacaram que a capacitação para a cooperação regional ocorre como agente de desenvolvimento regional, sendo referência para o desenvolvimento da região; prestação de serviço por meio de parques tecnológicos ou laboratórios; quando comunidade participa das decisões da universidade por meio dos conselhos; envolvimento com entidades regionais como ACIC, conselhos e outros tendo representantes nestas associações; quando existe a relação com o poder público municipal; quando o município tem a instituição como parceira; possuem envolvimento direto com a comunidade; na pesquisa está envolvida em resolver questões que tem impacto na sociedade local; 
Quadro 14.1 - Categoria 4 - Capacitação para a Cooperação Regional

\begin{tabular}{|c|c|c|c|c|c|c|c|c|c|}
\hline$\frac{\tilde{d}}{\frac{\pi}{0}}$ & $\begin{array}{l}\text { Evidências nas } \\
\text { Associações } \\
\text { Empresariais }\end{array}$ & 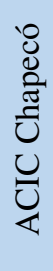 & 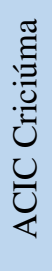 & 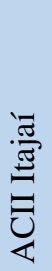 & 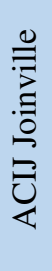 & 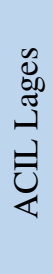 & 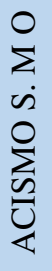 & 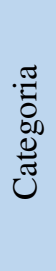 & 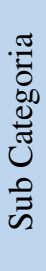 \\
\hline 1 & $\begin{array}{l}\text { A universidade é de } \\
\text { extrema importância e } \\
\text { desenvolve um papel } \\
\text { especial em apoio ao } \\
\text { desenvolvimento } \\
\text { regional }\end{array}$ & $\mathrm{x}$ & $\mathrm{X}$ & $\mathrm{x}$ & $\mathrm{X}$ & $\mathrm{X}$ & $\mathrm{X}$ & 4 & 3 \\
\hline 2 & $\begin{array}{l}\text { O segmento empresarial } \\
\text { está contemplado com } \\
\text { as ações } \\
\text { universidade }\end{array}$ & $\mathrm{X}$ & & $\mathrm{X}$ & $\mathrm{X}$ & & & 4 & 4 \\
\hline 3 & $\begin{array}{l}\text { A relação se estreita a } \\
\text { partir da participação } \\
\text { das decisões nos } \\
\text { conselhos } \\
\end{array}$ & $\mathrm{X}$ & & $\mathrm{X}$ & & & & 4 & 6 \\
\hline 4 & $\begin{array}{l}\text { Existe um vácuo entre o } \\
\text { mundo acadêmico e o } \\
\text { mundo empresarial }\end{array}$ & & $\mathrm{X}$ & & & $\mathrm{X}$ & $\mathrm{X}$ & 4 & 1 \\
\hline 5 & $\begin{array}{l}\text { Precisa existir conversa } \\
\text { entre os dois mundos } \\
\text { para estreitar o } \\
\text { relacionamento }\end{array}$ & & $\mathrm{X}$ & & $\mathrm{X}$ & $\mathrm{X}$ & $\mathrm{X}$ & 4 & 1 \\
\hline 6 & $\begin{array}{l}\text { Os dois mundos } \\
\text { precisam se juntar para } \\
\text { alavancar mais o } \\
\text { desenvolvimento } \\
\text { regional o envolvimento } \\
\text { entre ambos ainda é } \\
\text { muito tímido }\end{array}$ & & $\mathrm{x}$ & & $\mathrm{X}$ & $\mathrm{X}$ & $\mathrm{X}$ & 4 & 2 \\
\hline
\end{tabular}


Quadro 14.1 - Categoria 4 - Capacitação para a Cooperação Regional

(Continuação)

\begin{tabular}{|c|c|c|c|c|c|c|c|c|c|}
\hline$\frac{\tilde{0}}{0}$ & $\begin{array}{l}\text { Evidências nas } \\
\text { Associações } \\
\text { Empresariais }\end{array}$ & 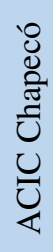 & 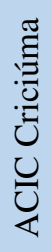 & 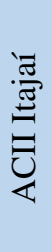 & 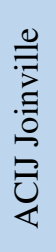 & 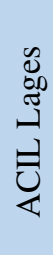 & 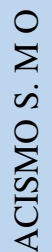 & 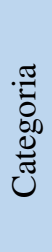 & 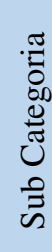 \\
\hline 7 & $\begin{array}{l}\text { Compete à universidade } \\
\text { pelo papel pesquisador } \\
\text { a fazer a frente e se } \\
\text { abrir buscando mais o } \\
\text { setor empresarial }\end{array}$ & & $\mathrm{X}$ & & & & & 4 & 2 \\
\hline 8 & $\begin{array}{l}\text { A representação da } \\
\text { universidade se dá por } \\
\text { meio da participação } \\
\text { nos conselhos }\end{array}$ & $\mathrm{x}$ & $\mathrm{x}$ & $\mathrm{X}$ & $\mathrm{x}$ & $\mathrm{X}$ & $\mathrm{x}$ & 4 & 6 \\
\hline 9 & $\begin{array}{l}\text { Deve se buscar } \\
\text { alternativas de aumentar } \\
\text { a velocidade de } \\
\text { aproximação }\end{array}$ & & $\mathrm{X}$ & & $\mathrm{x}$ & $\mathrm{x}$ & & 4 & 2 \\
\hline 10 & $\begin{array}{l}\text { A associação consegue } \\
\text { ter uma participação } \\
\text { bem ativa nas atividades } \\
\text { desenvolvidas pela } \\
\text { universidade }\end{array}$ & $\mathrm{x}$ & & $\mathrm{X}$ & $\mathrm{x}$ & & & 4 & 1 \\
\hline 11 & $\begin{array}{l}\text { As associações não } \\
\text { interferem nas decisões } \\
\text { da universidade, mas } \\
\text { sua opinião tem peso }\end{array}$ & & & & $\mathrm{x}$ & & & 4 & 4 \\
\hline 12 & $\begin{array}{l}\text { Percebem que a } \\
\text { Universidade tenta estar } \\
\text { no meio da } \\
\text { comunidade, mas nem } \\
\text { sempre consegue }\end{array}$ & & & & & $\mathrm{x}$ & & 4 & 1 \\
\hline
\end{tabular}


Quadro 14.1 - Categoria 4 - Capacitação para a Cooperação Regional

\begin{tabular}{|c|c|c|c|c|c|c|c|c|c|}
\hline$\frac{\Xi}{0}$ & $\begin{array}{l}\text { Evidências } \\
\text { Associações } \\
\text { Empresariais }\end{array}$ & 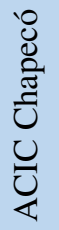 & 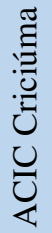 & 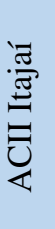 & 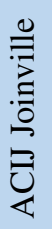 & 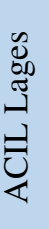 & 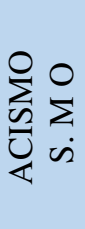 & 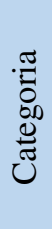 & 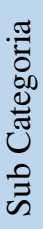 \\
\hline 13 & $\begin{array}{l}\text { O segmento empresarial } \\
\text { participa pouco das } \\
\text { atividades promovidas } \\
\text { pela universidade }\end{array}$ & & $\mathrm{X}$ & & $\mathrm{X}$ & X & X & 2 & 2 \\
\hline 14 & $\begin{array}{l}\text { Falta a comunidade } \\
\text { saber o que a } \\
\text { universidade tem além } \\
\text { dos cursos de graduação } \\
\text { e pós- graduação }\end{array}$ & & & & & $\mathrm{X}$ & & 4 & 3 \\
\hline
\end{tabular}

Fonte: dados da pesquisa

Para as associações empresariais a capacitação para a cooperação regional, destacou que a universidade é de extrema importância e desenvolve um papel especial em apoio ao desenvolvimento regional e a representação da universidade se dá por meio da participação nos conselhos. 
Quadro 14.2 - Análise Categoria 04 - Capacitação para a Cooperação Regional

\begin{tabular}{|c|c|c|c|c|c|}
\hline \multirow{2}{*}{$\frac{\tilde{d}}{\tilde{D}}$} & \multirow{2}{*}{ Subcategorias } & \multicolumn{2}{|c|}{ ICES } & \multicolumn{2}{|c|}{ ACICs } \\
\hline & & Quant. & $\%$ & Quant. & $\%$ \\
\hline 1 & $\begin{array}{l}\text { Mecanismos para promover } \\
\text { o } \\
\text { universidade-região }\end{array}$ & 6 & $33,33 \%$ & 4 & $28,57 \%$ \\
\hline 2 & $\begin{array}{lll}\text { Promoção conjunta } & \text { do } \\
\text { diálogo e iniciativas } & \text { de } \\
\text { interesse regional } & \\
\end{array}$ & 7 & $38,89 \%$ & 4 & $28,57 \%$ \\
\hline 3 & $\begin{array}{l}\text { Avaliação e mapeamento do } \\
\text { impacto da universidade }\end{array}$ & 1 & $5,56 \%$ & 2 & $14,29 \%$ \\
\hline 4 & $\begin{array}{lr}\text { Capacitação } & \text { institucional } \\
\text { para o } & \text { envolvimento } \\
\text { regional } & \\
\end{array}$ & 2 & $11,11 \%$ & 2 & $14,29 \%$ \\
\hline 5 & $\begin{array}{l}\text { Gerenciamento dos recursos } \\
\text { humanos e financeiros }\end{array}$ & 0 & $0 \%$ & 0 & 0 \\
\hline 6 & $\begin{array}{l}\text { Criação de uma nova cultura } \\
\text { organizacional }\end{array}$ & 2 & $11,11 \%$ & 2 & $14,29 \%$ \\
\hline & Total & 18 & $100 \%$ & 14 & $100 \%$ \\
\hline
\end{tabular}

Fonte: dados da pesquisa

Nessa quarta categoria, destaca-se a participação das ICES como agentes de desenvolvimento regional, sendo percebido como ponto positivo pelas instituições de ensino e pelas associações empresariais, porém, existem críticas quanto ao distanciamento entre a academia e o setor produtivo.

As evidências destacadas nessa pesquisa demonstram as percepções das associações empresariais que afirmam que a academia precisa se voltar para o setor produtivo, buscando contribuir por meio da pesquisa o desenvolvimento regional. Em algumas regiões, existe a necessidade de cursos voltados para as competências econômicas da região, fato apontado como positivo no norte do estado, onde as duas ICES visitadas possuem cursos voltados para as demandas regionais.

Diante dessas considerações e na tentativa de demonstrar de maneira mais clara, a contribuição desta pesquisa em relação aos seus objetivos, destacam-se as características e percepções identificadas nas entrevistas, que vão de encontro com o descrito no referencial teórico 
dessa dissertação, pois, os diversos autores pontuam o papel destacado das universidades em responder as demandas da sociedade.

\subsection{ANÁLISE DOS DADOS DA PESQUISA}

A dissertação foi construída a partir de pesquisa em artigos e bibliografias sobre as características das ICES e as contribuições para o crescimento e desenvolvimento regional. Procurou-se demonstrar como a população e a classe empresarial percebem as interações entre as ICES e a comunidade regional.

Inicialmente procurou-se entender a origem das instituições de ensino superior, visando compreender as características comunitárias dessas IES, que surgiram por meio de fundações educacionais criadas pelos municípios do estado de Santa Catarina. Atualmente, são grandes instituições, devido a sua representação na comunidade regional, sendo consideradas ícones nos municípios sedes em que atuam.

As universidades interagem com as comunidades, por meio do ensino, pesquisa e extensão, conforme pode ser evidenciado na figura 09, demonstrando o modelo sistêmico mencionado por (REIS; BANDOS, 2012).

Figura 09 - Abordagem sistêmica da responsabilidade social das IES

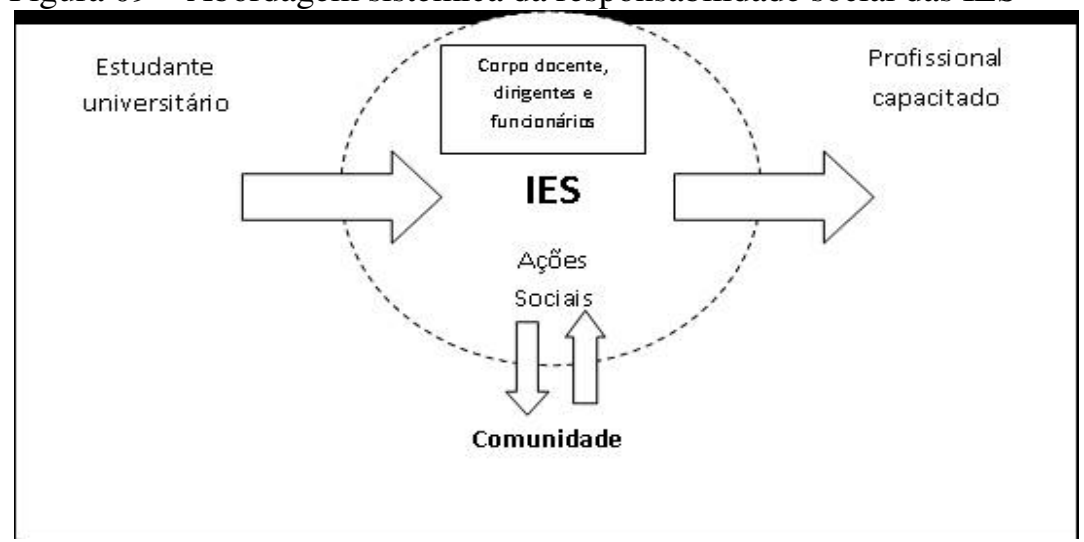

Fonte: Reis e Bandos (2012).

A abordagem sistêmica da responsabilidade social das IES abordado por Reis e Bandos (2012), foram identificadas nas entrevistas com os gestores das ICES e com os representantes das associações empresariais. A interação das instituições foi apontada pelas atividades 
de caráter social realizados pelo corpo docente e discente por meio de projetos de extensão e realizando ações culturais e esportivas.

Ficaram evidentes que as ICES, precisam ir além do ensino, precisam buscar alternativas que fortaleçam os pilares que as caracterizam como universidade. Fato mencionado por Fleck (2011), para que as ICES possam contribuir para o desenvolvimento regional, devem se engajar nos objetivos que proporcionem o crescimento e melhorias socioeconômicas da região.

Os impactos regionais das ICES ficaram evidentes pelas ações e pelos sentimentos demonstrados nas falas dos gestores das instituições e pelos representantes das associações empresariais, corroborando com Serra e Rolim (2009), conforme demonstra a figura 10:

Figura 10 - Impactos regionais de uma universidade

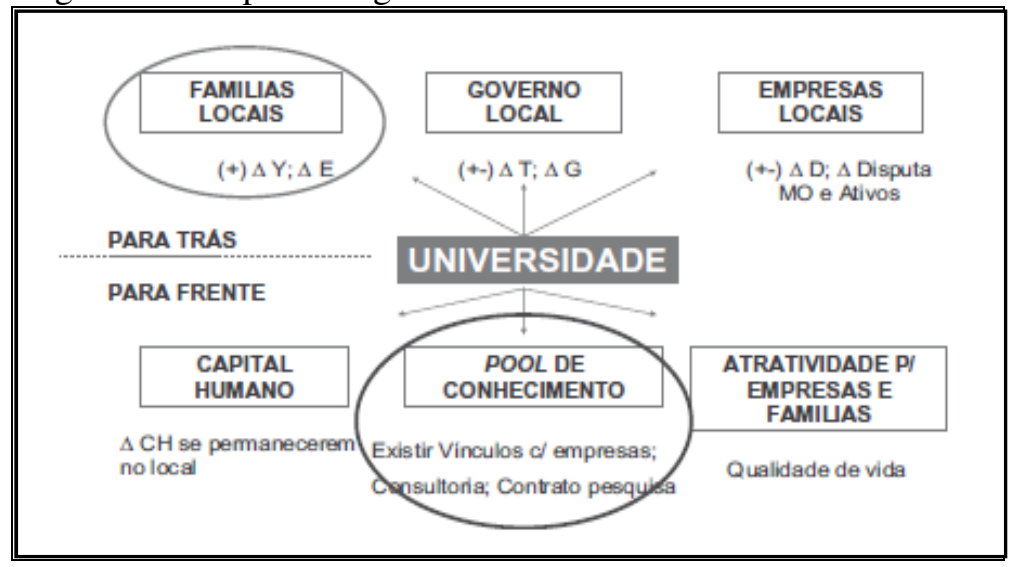

Fonte: Serra e Rolim (2009a).

A teoria sobre os impactos regionais de uma universidade abordado por Serra e Rolim (2009), é desconhecida pelos gestores das IES e dos representantes das associações empresarias, no entanto, as entrevistas demostrou que o Pool de Conhecimento necessita melhorar para justificar a existência de uma universidade como promotora do desenvolvimento em uma região.

Outro impacto reconhecido nas entrevistas foi a movimentação de renda regional abordado por Gumbowaky (2014), pois, com o crescimento e a valorização imobiliária das regiões, o desenvolvimento das atividades comerciais gerado pelo aumento do consumo de alunos, docentes e funcionários, bem como dos negócios imobiliários no 
entorno das universidades, pode se constituir em contribuição das universidades para o desenvolvimento regional ou local.

As características propostas por Fleck (2011), conforme modelo da figura 11, demonstra que existe a interação entre a tríade ensino, pesquisa e extensão, como sendo essencial para que ocorra o desenvolvimento regional. Apesar desse modelo não ser evidente em todas as universidades e nos municípios visitados, o pensamento dos gestores e dos representantes das associações é que o desenvolvimento é propiciado por esta interação. As ICES devem se tornar interativas e vinculadas com as questões socioeconômicas das regiões, criando mecanismos que facilitem a relação com o meio empresarial e a sociedade.

Figura 11 - Modelo teórico - inserção da tríade ensino, pesquisa e extensão no desenvolvimento regional

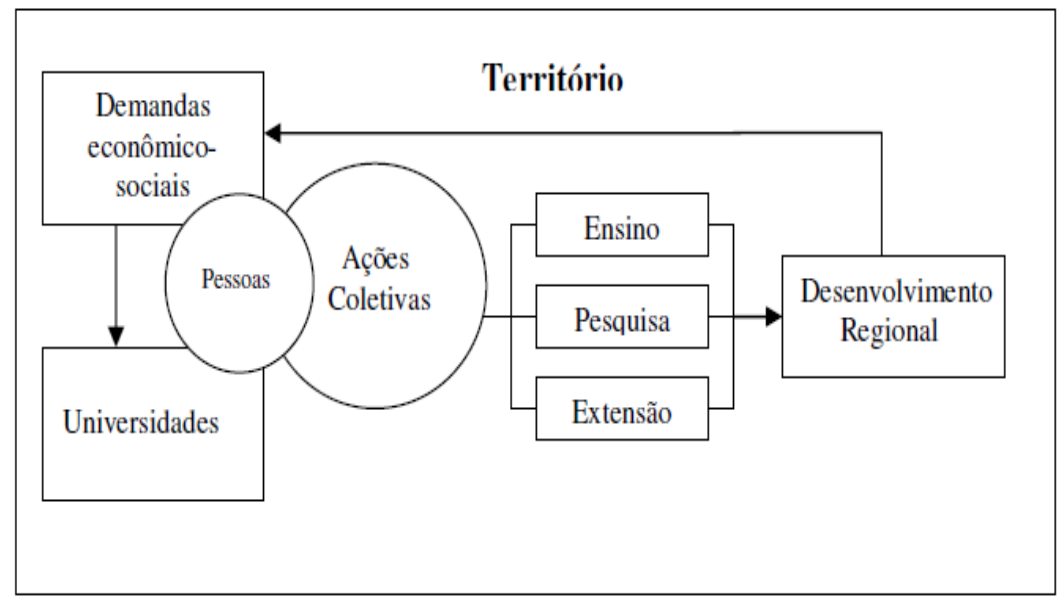

Fonte: Fleck (2011).

A inserção da tríade ensino, pesquisa e extensão no desenvolvimento regional proposto por Rolin e Serra (2009), foi evidenciado nas universidades e nas associações empresarias visitadas, por meio de um sistema regional de inovação caracterizado por uma região onde existem meios de ligações e comunicação interativas entre os agentes propulsores do desenvolvimento. Compreendeu-se que estes agentes podem ser constituídos por universidades, laboratórios de pesquisa básica, laboratórios de pesquisas aplicada, agências de transferência de tecnologia, organizações regionais de governança, 
públicas privadas e empresários dispostos a desenvolver novos produtos em parcerias de risco, com pequenas e grandes empresas interagindo (ROLIM; SERRA, 2009a).

Figura 12- Universidade e região

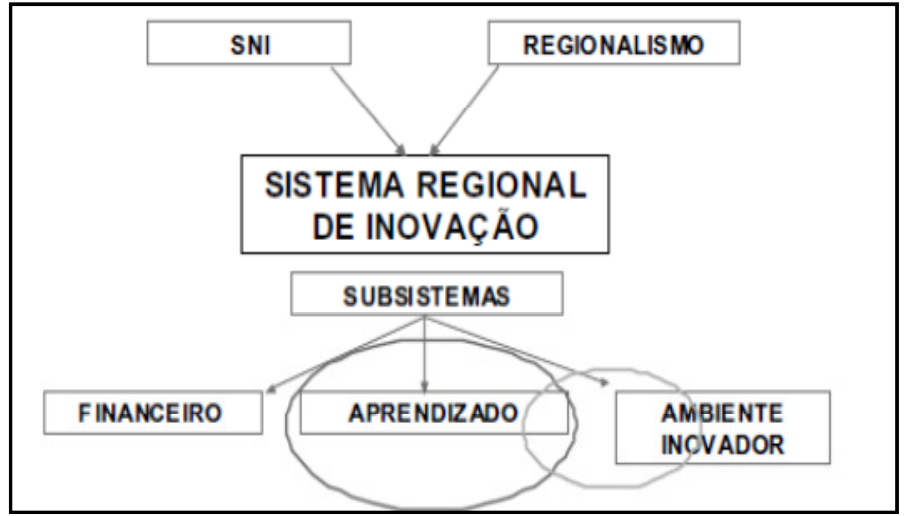

Fonte: Rolim e Serra (2009a).

Quanto a relação entre a universidade e a região, proposto por Caldarelli, Camara e Perdigão (2015), os gestores das universidades e os representantes das associações empresariais afirmaram que as instituições propiciaram benefícios para a região por meio das ações de ensino, de pesquisa e de extensão realizadas pelas ICES.

Figura 13 - Relação entre universidade e região

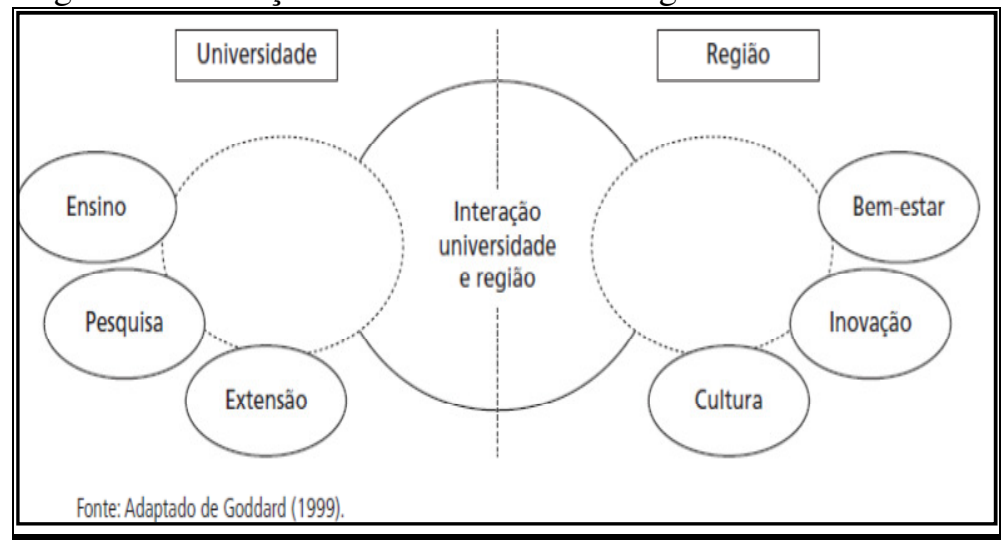

Fonte: Caldarelli, Camara e Perdigão, (2015) 
Com esses resultados, foi possível demonstrar que as ações das ICES do Sistema ACAFE podem ser caracterizados como agentes de desenvolvimento econômico das regiões em que atuam. Porém, ficou evidente que, apesar das ações promovidas contribuírem significativamente para o desenvolvimento, existe um distanciamento entre a academia e o setor privado empresarial, sendo necessário buscar mecanismos para ajustá-lo.

Dessa maneira, entende-se que as universidades são fundamentais para o que atualmente está se denominando de sociedade do conhecimento, e que o conhecimento está sendo tão valorizado como capital intelectual. Nas entrevistas ficou evidente ao que Mota (1999) menciona, que o principal benefício para a universidade, é o conhecimento que ela adquire sobre o funcionamento e a necessidade das instituições para as quais está formando recursos humanos.

Apesar dos objetivos das universidades e das empresas serem diferentes, se faz necessário que ambas interajam para buscar o desenvolvimento da sociedade e da região onde estão inseridas, porém, as ações necessárias, ainda é tímida de ambas as partes. Assim, na sociedade do conhecimento, a dinâmica da inovação só acontece quando vinculada aos processos de aprendizagem do conhecimento, que está diretamente vinculada aos processos de interação entre as organizações e agentes que permitem gerar, reproduzir e retroalimentar processos de aprendizagem, convertendo-os em atividades inovadoras (MOTA, 1999).

Como evidenciado nas entrevistas, apesar das universidades promoverem diversas ações que contribuem com o desenvolvimento regional - principalmente na assistência da população menos favorecida economicamente - a interação com o setor produtivo necessita de esforços conjuntos para que ocorra a triple hélix. Mota (1999) menciona que o processo de parceria entre universidade e empresa seguem algumas fases que inicia no diálogo, intensifica-se com a convivência, até atingir a identificação cultural e a confiança.

Conforme Nunes e Silva (2011), o conhecimento cientifico produzido pelas ICES necessita transformar a realidade social, intervindo em suas deficiências e não se limitando, apenas a formação de alunos regulares. A pesquisa demonstrou ser esse o anseio da sociedade produtiva. As pesquisas realizadas pelas universidades precisam promover mudanças na sociedade e principalmente, contribuir no seu processo produtivo.

Ainda segundo Nunes e Silva (2011), a relação entre pesquisa e extensão ocorre quando a produção do conhecimento seja capaz de 
transformar a sociedade, e o que se vê nas universidades são pesquisas e extensão voltadas para o assistencialismo e poucas ações para o setor produtivo e mudanças tecnológicas que contribuam na forma de agir, pensar e fazer na sociedade onde se localizam. 


\section{CONSIDERAÇÕES FINAIS}

Entende-se que o número de universidades e associações contempladas na pesquisa deu suporte ao cumprimento das metas e objetivos propostos, tendo em vista a representatividade no estado e na região onde cada uma delas desenvolvem suas atividades. Assim, o presente trabalho pode contribuir para despertar o interesse de novos pesquisadores para aprofundar o estudo ora iniciado, visando colaborar com o Sistema ACAFE e com as instituições de ensino, no entendimento do distanciamento da academia e do setor produtivo, mesmo que as partes entendam que a universidade é um dos agentes de desenvolvimento regional.

Uma das principais contribuições desse trabalho foi demonstrar a percepção da comunidade empresarial sobre as ações promovidas pelas ICES nas regiões onde atuam. Assim como, demonstrar o que as entidades representativas empresariais percebem da atuação das universidades comunitárias. As evidências apontadas nas entrevistas contribuem para que as universidades analisem a condução de suas ações para o desenvolvimento econômico e social.

As entrevistas demonstram que existem pensamentos comuns entre as partes entrevistadas, tanto positivamente, quanto para o que precisa ser melhorado, como por exemplo, o fato da universidade ser essencial como um agente promotor do desenvolvimento regional, e que sem a universidade não se conseguiria ter alcançado o nível de desenvolvimento atual. Porém, afirmam que há um distanciamento grande entre elas, e que a universidade precisa trabalhar em conjunto com o setor produtivo.

As universidades necessitam buscar alternativas que incentivem os pesquisadores a se aproximarem da área produtiva que possam contribuir com o conhecimento científico em melhorias produtivas nas empresas da região, assim como no desenvolvimento social. Esse incentivo necessita ser promovido em todas as áreas do conhecimento, e os próprios pesquisadores precisam entender que podem contribuir de alguma forma, independente da área.

Como alternativa, para despertar o interesse de aproximação entre as partes, sugere-se que haja divulgação das ações que as universidades realizam na área social e nas pesquisas, pois, se a comunidade regional (re)conhecer o potencial das ações desenvolvidas pelas universidades, pode gerar interesse em patrocínio de pesquisa, por exemplo.

Constatou-se que a sociedade não tem conhecimento do que se pesquisa na universidade, o que torna fundamental mostrar $\mathrm{o}$ 
conhecimento desenvolvido e que a universidade pode analisar um processo, ou incentivar melhorias nos produtos, processos ou rotinas. Esta aproximação pode iniciar-se via projetos de pesquisa de iniciação científica, por grupos de pesquisa e, de acordo com a complexidade, pode gerar uma prestação de serviço. As ICES Precisam demonstrar que além da formação técnica, podem estar presentes de maneira sólida na prestação de serviço técnico científico à sociedade.

A pesquisa demonstrou que as universidades atuam de maneira significativa na extensão assistencial, porém, na prestação de serviço, o processo é incipiente, necessitando um pensamento acadêmico inovador na nova sociedade do conhecimento. É necessário utilizar o conhecimento científico para contribuir com inovações e avanços técnicos científicos.

Apesar da forte atuação das ICES no assistencialismo, a sociedade não tem o conhecimento do que realmente é promovido nessa área pelas universidades, demonstrando a necessidade de uma publicidade com divulgação regional do que estas grandes instituições fazem semestralmente, dando maior notoriedade do que fazem em prol da sociedade além do ensino.

A comunidade empresarial recebe o conhecimento das universidades, absorvendo a mão de obra qualificada oriunda dessas instituições de ensino, que possui a prerrogativa de um ensino de qualidade. Em algumas regiões existem alguns ensaios de outras iniciativas, como eventos abertos à comunidade, com palestrantes e pesquisadores de outras regiões, que contribui para divulgar as pesquisas em rede estadual ou nacional.

Percebeu-se a importância da universidade procurar a classe empresarial para prestação de serviço, porém, é fundamental que toda a comunidade tenha conhecimento sobre o que a universidade está pesquisando para solucionar problemas e contribuir para o desenvolvimento da região. Agregado a isso, vem a divulgação do potencial das universidades em desenvolver pesquisas técnicas para as empresas da região ou contribuindo com assessorias para as empresas.

A pesquisa evidenciou que as universidades e as associações representativas nas diversas regiões do estado, pensam de maneira semelhante quanto ao papel das universidades no desenvolvimento regional da sociedade do conhecimento, e há o desejo de construir laços mais estreitos de relacionamento.

Para trabalhos futuros, sugere-se verificar a percepção da comunidade em geral dos municípios sobre as universidades comunitárias, bem como ampliar a pesquisa para as demais ICES 
comunitárias do estado, além de aplicar entrevistas semiestruturadas junto aos gestores públicos, prefeitos e secretários de estados. 


\section{REFERÊNCIAS}

ALVES, M. Como escrever teses e monografias: um roteiro passo a passo. Rio de Janeiro: Elsever, 2007.

ARBO, P.; BENNEWORTH, P. Understanding the Regional Contribution of Higher Education Institutions: A Literature Review. OECD Education Working Papers, Paris, n. 9, Paris, 2007.

Disponível em: <http://dx.doi.org/10.1787/161208155312>. Acesso em: 10 mar. 2017

BANDEIRA, A. C. M.; NOVO, L. F. A Universidade e Desenvolvimento Regional: Análise da Contribuição do Programa de Pós-Graduação em Ciência e Tecnologia de Sementes da UFPEL. In: XI COLÓQUIO INTERNACIONAL SOBRE GESTÃO UNIVERSITÁRIA NA AMERICA LATINA-GESTÃO UNIVERSITÁRIA, 11., Florianópolis, 2011.

BERNHEIM, C. T.; CHAUÍ, M. S. Desafios da universidade na sociedade do conhecimento: cinco anos depois da conferência mundial sobre educação superior / Carlos Tünnermann Bernheim e Marilena de Souza Chaú. Brasília: UNESCO, 2008.

BITTAR, M. O Ensino Superior privado no Brasil e a formação do segmento das universidades comunitárias. Universidade Católica Dom Bosco. Pagina comunitária. 2009.

BOVO, J. M (Org.). Impactos econômicos e financeiros da UNESP para os municípios. São Paulo: Fundação Editora da UNESP, 2003.

BRASIL. Lei $\mathbf{n}^{\mathbf{0}} \mathbf{1 2 . 8 8 1}$, de 12 de novembro de 2013. Dispõe sobre a definição, qualificação, prerrogativas e finalidades das Instituições Comunitárias de Educação Superior - ICES, disciplina o Termo de Parceria e dá outras providências.Disponível em:

<http://www.comunitarias.org.br/>. Acesso em: 10 jan. 2016.

BRASILEIRO, S. F.; GONÇALVES, E. F.; TARGINO, M. das G. Novas perspectivas para a responsabilidade Social Universitária Reflexão sobre o Projeto de educação popular e apoio a saúde da Família. Universidade federal de Teresina. Revista FSA, Teresina, v. 11, n. 3, art. 8, p. 208-229, jul./set. 2014. 
BUENO, N. P. Lógica da Ação Coletiva, Instituições e Crescimento Econômico: Uma Resenha Temática sobre a Nova Economia Institucional. Revista Economia, Brasília (DF), v. 5, n. 2, p. 343-402, jun./dez. 2004.

CABELlEIRA, D. M. Comunidades de Prática - Conceitos e Reflexões para uma Estratégia de Gestão do Conhecimento. In: ENCONTRO DA ANPAD RIO DE JANEIRO, 31., Rio de Janeiro 2007. Anais.... 2007. Disponivel em: <http://www.anpad.org.br/admin/pdf/ADI-B2953.pdf>. Acesso em: 15 jan. 2017.

CALDARELli, C. E.; CAMARA, M. R. G.; PERDIGÃO, C. Instituições de Ensino Superior e Desenvolvimento Econômico: o caso das universidades estaduais paranaenses. Revista Planejamento e Políticas Públicas, n. 44, jan./jun. 2015.

CAVICHIOLI, R. das G. C. Sociedade do conhecimento: a educação como pilar. Revista de Educação. v. 13, n. 15, p. 141-154, out. 2011.

COOKE, A. I. Responsabilidade social universitária: contribuições para o fortalecimento do debate no Brasil. Revista da Associação Brasileira de Mantenedoras de Ensino Superior, Brasília, v. 24, n. 36, p. 7-22, jun. 2006. Edição Especial.

COOKE, P.; BRACZYK, H-J.; HEIDENREICH, M. Regional innovation systems: the role of governances in a globalized world. London: UC1. Press, 1998.

COOKE, P.; MORGAN, K.. The associatinal economy: firms, regional and innovaçtion. London: Oxford University Press, 1998.

CORRÊA, F. L.; FRANÇA, S. L. B.; BEZERRA, M. J. S. Sociedade do conhecimento: evolução, desafios, informação, aprendizagem e propostas para um mundo mais inclusivo. 2015. Disponível em: < http://www.convibra.com.br/upload/paper/2015/29/2015_29_11805.pdf >. Acesso em: 10 jan. 2017.

CRESWEL, J. W., Projeto de pesquisa: métodos qualitativos, quantitativo e misto. 3. ed. Porto Alegre: Artmed, 2010. 
CZELUSNIAK, V. A.; CORDEIRO, P. V. M.; DERGIINT, D. E. A. Contribuições dos quadros teóricos da tríplice hélice e dos estudos da ciência tecnologia e sociedade para políticas de inovação tecnológica na América latina. 2010. Disponível em: <http://www.esocite2010.escyt.org/download_ponencia.php?file=Artigo _CTS_20100618(4)1276900885.doc\&Code=3rjvntflbqnlhptfnmrg7a2fis p5mkp92xh57mwbq9dlqb5u1ws6tjp06byb.>. Acesso em: 08 maio 2016.

EXTENSÃO Universitária: organização e sistematização. In: CORRÊA, Edison José (Org.). Fórum de Pró-Reitores de Extensão das Universidades Públicas Brasileiras. Belo Horizonte: Coopmed, 2007.

FECAM. Educação. [2017]. Disponível em: <http://www.fecam.org. br/>. Acesso em: 25 maio 2017.

FEREIRA, A.; LEOPOLDI, M. A. A contribuição da universidade pública para a inovação e o desenvolvimento regional: a percepção de gestores e pesquisadores. Revista GUAL, Florianópolis, v. 6, n. 1, p 6082, jan. 2013.

FLECK, C. F. do. A tríade ensino-pesquisa-extensão e os vetores para o desenvolvimento regional. Revista Brasileira de Gestão e Desenvolvimento Regional, Taubaté, v. 7, n. 3, p. 270-298, set./dez. 2011,

FOLLMANN, J. I. As universidades confessionais e a sua natureza comunitária e Pública não estatal. Instituições comunitárias: instituições públicas não estatais. Santa Cruz do Sul: Edunisc, 2009.

FRANTZ, W. Universidade Comunitária: uma iniciativa pública nãoestatal em construção. 2004. Disponível em:

<http://www.comunitarias.org.br/>. Acesso em: 10 jan. 2016.

GIL, A. C. Como elaborar projetos de pesquisa. 4. ed. São Paulo: Atlas, 2008.

GOEBEL, M. A.; MIURA, M. N. A universidade como fator de desenvolvimento: o caso do município de Toledo-PR. Revista Expectativa Secretariado Executivo, v. 3, n. 3, p. 35-47, 2004. 
GOMES, M. A. S.; PEREIRA, F. E. C. Hélice Tríplice: um Ensaio teórico sobre a relação Universidade-empresa-governo em busca da inovação. Int Knowl. Eng Manage., Florianópolis, v. 4, n. 8, p. 136155, mar./jun. 2015.

GUIMARÃES, P. B; MAGALHÃES, A. de P. A importância da interdisciplinaridade no ensino superior universitário no contexto da sociedade do conhecimento. Revista Científica Vozes dos Vales, v. 5, n. 9, maio 2016.

GUMBOWAKY, A. Instituições de ensino superior fundacionais do estado de Santa Catarina: compromissos com o desenvolvimento regional. Revista Univap, São José dos Campos, v. 20, n. 36, dez. 2014.

LIMA, L. G. de. Contribuições das instituições de educação superior da associação catarinense de fundações educacionais a Santa Catarina e ao Brasil. In: SCHIMIT, João Pedro (Org.). Instituições comunitárias: instituições públicas não estatais. Santa Cruz do Sul: Edunisc, 2009. p. 93-107.

MACHADO, A. M. N. Universidades Comunitárias: Um modelo brasileiro para interiorizar a educação superior. In: In: SCHIMIT, João Pedro (Org.). Instituições comunitárias: instituições públicas não estatais. Santa Cruz do Sul: Edunisc, 2009. p. 74-92.

MAGALHÃES, A. D. D. et al. A universidade e o desenvolvimento regional: o caso da UFVJM - FAPEMIG. In: SEMINÁRIO

ECONOMIA MINEIRA, 15., Diamantina, 2012. Anais... 2012.

Disponível em: <http://diamantina.cedeplar.ufmg.br/2012/arquivos/A\% 20UNIVERSIDADE\%20E\%20O\%20DESENVOLVIMENTO\%20REG IONAL.pdf $>$. Acesso em: 12 jan. 2017.

MELO, A. F. de. Globalização, sociedade do conhecimento e educação superior: os sinais de Bolonha e os desafios do Brasil e da América Latina. Brasília: Universidade de Brasília: 2011.

MOTA, T. L. Nogueira da Gama. Interação universidade-empresa na sociedade do conhecimento: reflexões e realidade. Ciência da Informação, v. 28, n. 1, p. 79-86, 1999. 
NUNES, A. L. de P. F.; SILVA,_M. B. da C. A extensão universitária no ensino superior e a Sociedade. Mal-Estar e Sociedade, Barbacena, v. 4, n. 7, p. 119-133, jul./dez. 2011.

PHILIPPI JUNIOR, A.; NETO, A. J. S. Interdisciplinaridade em ciência tecnologia e inovação. Barueri SP: Manole, 2011.

REIS, A. L; BANDOS, M. F. C. A responsabilidade social de instituições de ensino superior: uma reflexão sistêmica tendo em vista o desenvolvimento. PUC Minas - campus Poços de Caldas. Revista Gestão \& Conhecimento, Nov. 2012. Edição Especial.

RIBEIRO; R. M. da C. A extensão universitária como indicativo de responsabilidade social. Revista Diálogos: pesquisa em extensão universitária, Brasília, v.15, n.1, jul. 2011.

RICHER, L. E; LEIDENS, L. V. - O marco legal do terceiro setor e sua (in)compatibilidade normativa com as instituições comunitárias. In: SCHIMIT, João Pedro (Org.). Instituições comunitárias: instituições públicas não estatais. Santa Cruz do Sul: Edunisc, 2009. p. 38-55.

ROLIM, C. Índice de inserção regional das instituições de ensino superior. 2009. Disponível em:

<http://www.apdr.pt/congresso/2009/pdf>. Acesso em: 10 mar. 2016.

ROLIM, C; SERRA, M. Ensino superior e desenvolvimento regional: avaliação do impacto econômico de longo-prazo. Revista Brasileira de Estudos Regionais e Urbanos, v. 3, n. 1, p. 85-106, 2009a.

ROLIM, C; SERRA, M. Instituições de Ensino Superior e Desenvolvimento Regional: O Caso da Região Norte do Paraná. Revista de Economia, v. 35, n. 3, p. 87-102, set./dez. 2009 b.

ROLIM, C; SERRA, M. Desenvolvimento e engajamento regional: o papel das universidades. In: SILVEIRA, Rogério Leandro Lima da (Org.). Observando o desenvolvimento regional brasileiro: processo, políticas e planejamento. Santa Cruz do Sul : EDUNISC, 2013. p. 7288. 
ROSA-CASTRO, R. de M; MARQUES JÚNIOR, E; ROSA MARQUES, E de M. Universidades comunitárias: características e desafios. In: SEMINÁRIO INTERNACIONAL DE EDUCAÇÃO SUPERIOR. 2014. Anais eletrônicos... 2014. Disponível em: $<$ http://uniso.br/publicacoes/anais_eletronicos/2014/2_es_politicas_publ icas/12.pdf>. Acesso em: 28 maio 2017.

ROSSA, R. M; GARCIA, J. R.; LEZANA, Á. G. R. A abordagem hélice tríplice das relações entre universidade-Indústria- Governo. In: SIMPOI 2013. Anais... 2013. Disponível em: <http://www.simpoi.fgvsp.br/ arquivo/2013/ artigos/E2013_T00192_PCN67304.pdf>. Acesso em: 08 maio 2016.

SANTOS JUNIOR, A. L. A extensão universitária e os entre-laços dos saberes. 2013. 248 f. Tese (Doutorado em Educação) - Programa de Pós-graduação em Educação da Universidade Federal da Bahia. Bahia, 2013.

SANTOS, A. P. dos; CERQUEIRA, E. A. de. ENSINO SUPERIOR: trajetória histórica e políticas recentes. In: COLÓQUIO INTERNACIONAL SOBRE GESTÃO UNIVERSITÁRIA NA AMÉRICA DO SUL, 9., 2009. Anais... 2009. Disponível em: < https://repositorio.ufsc.br/xmlui/handle/123456789/35836>. Acesso em: 20 jan. 2017.

SCHIMDT, J. P. Comunidade e comunitarismo: considerações sobre a inovação da ordem sociopolítica. Ciências Sociais. São Leopoldo, v. 47, n. 3, p. 300-313, set./dez. 2011.

SCHMIDT, J. P. O Comunitário em Tempos de Público não Estatal. Avaliação. Sorocaba, v. 15, n. 1, p. 9-40, mar. 2010.

SCHNEIDER, J. R. A Escola Comunitária - Trama Entre Sujeitos e Instituição, 2008. Dissertação (Mestrado em Teologia) - Escola Superior de Teologia Instituto Ecumênico de Pós-Graduação em Teologia, São Leopoldo, 2008.

SIDEMS. IDMS de Criciúma - 2016. 2017a. Disponível em: < http://indicadores.fecam.org.br/indice/municipal/ano/2017/codMunicipi o/75>. Acesso em: 15 maio 2017. 
SIDEMS. Índice de Desenvolvimento Sustentável dos Municípios

Catarinenses - 2016. 2017b. Disponível em: <http://indicadores.fecam. org.br/indice/estadual/ano/2017>. Acesso em: 15 maio 2017.

SIDEMS. Mesorregiões catarinenses - média dos índices municipais - 2016. 2017c. Disponível em: < http://indicadores.fecam.org.br/cms/ pagina/ver/codMapaItem/87813/ano/2017>. Acesso em: 15 maio 2017.

SIDEMS. Metodologia IDMS. 2017d. Disponível em: < http://indicadores.fecam.org.br/cms/pagina/ver/codMapaItem/87813/ano /2017>. Acesso em: 15 maio 2017.

SILVA, F. M. da; MELO, P. A. de. Universidade e compromisso social: a prática da Universidade Federal de Santa Catarina. 2010. Disponível em: <https://repositorio.ufsc.br/bitstream/handle/123456789/ 97090/universidade \%20e\%20compromisso\%20social\%20a\%20pr\%c1ti ca\%20da\%20universidade\%20.pdf? sequence $=1>$. Acesso em: 01 maio 2017.

SIRQUEIRA, F. J. S.; FERRAZ, M. I. F. A universidade como fator de desenvolvimento regional. 2014. Disponível em

<http://www.uesb.br/eventos/semana_economia/2015/arquivos/13.pdf>. Acesso em: 25 abr. 2016.

VENANZI, D; SANDANO, W. Universidades comunitárias: as características na prestação de serviços públicos. Revista Temas em Educação, João Pessoa, v. 23, n. 2, p. 140-155, jul./dez. 2014.

VIANA, M. dos S. O desafio social do saber universitário. REA, n. 99, ago. 2009.

VOGT, P. O. - Capital Social e Instituições Comunitárias no Sul do Brasil. In: SCHIMIT, João Pedro (Org.). Instituições comunitárias: instituições públicas não estatais. Santa Cruz do Sul: Edunisc, 2009.

VOLPATO, G. A universidade na sua constituição: criação, reformas e implicações político-epistemológicas. Rev. Bras. Est Pedag., Brasília, v. 92, n. 232, set./dez. 2011.

ZABALZA, M. O ensino universitário e seus protagonistas. Trad Ernani Rosa. Porto Alegre: Artmed, 2004. 
APÊNDICE(S) 


\section{APÊNDICE A: CARACTERÍSTICAS E PERCEPÇÕES DETECTADAS NAS ENTREVISTAS}

\section{Gestores das Instituições}

$\checkmark \quad$ Os gestores possuem longo tempo de trabalho nas instituições;

$\checkmark \quad$ As instituições possuem relacionamento com a comunidade;

$\checkmark \quad$ Entendem que as instituições contribuem com a promoção do desenvolvimento sendo um dos agentes responsáveis pelo desenvolvimento regional;

$\checkmark \quad$ Possuem atuações nas áreas do esporte, atividades culturais e na saúde;

$\checkmark \quad$ Possuem parques científicos tecnológicos como instrumento de relação como setor produtivo;

$\checkmark \quad$ Possuem desenvolvimento de propriedade intelectual;

$\checkmark \quad$ Possuem desenvolvimento de produtos e patentes e pesquisa de P\&D;

$\checkmark \quad$ Possuem em suas missões produzir conhecimento promovendo o desenvolvimento regional;

$\checkmark \quad$ Existe a participação da comunidade nas decisões;

$\checkmark \quad$ As decisões institucionais são colegiadas;

$\checkmark \quad$ Possuem relação com o setor produtivo e produção da inovação;

$\checkmark \quad$ Possuem o entendimento que é uma das funções das instituições em promover o desenvolvimento;

$\checkmark \quad$ Falta o estreitamento do relacionamento com o setor produtivo;

$\checkmark \quad$ As instituições não têm cor e nem partido;

$\checkmark \quad$ Tem as atividades de extensão como diferencial, sendo a Extensão na área da saúde um dos diferenciais;

$\checkmark \quad$ As instituições são conhecidas pelas atividades desenvolvidas;

$\checkmark \quad$ Atendem as necessidades das comunidades mais carentes;

$\checkmark \quad$ Os projetos de pesquisa e extensão são mantidos com recursos próprios;

$\checkmark \quad$ Possuem relação próxima com o poder público municipal, sendo parceiras em muitas atividades;

$\checkmark \quad$ Tem o pensamento que as políticas públicas deixam a desejar para com as comunitárias;

$\checkmark \quad$ Os projetos de extensão atacam os problemas locais; As instituições se preocupam primeiro com o ambiente local que estão inseridas, e a pesquisa e a extensão estão voltadas para o local. 
Existe a preocupação com a entrada das instituições privadas e principalmente do Capital estrangeiro no ensino superior, sendo este um desafio muito grande;

A comunidade respeita muito a instituição, colocando-a como essencial para desenvolvimento;

A pesquisa de inovação, ainda se é um pouco incipiente;

As instituições que terão sucesso são aquelas que conseguirem entender o movimento da promoção do desenvolvimento regional pela inovação;

$\checkmark \quad$ Podem ser consideradas, como a comunidade do conhecimento, porque querem se transformar em um grande setor de soluções para comunidade na promoção do desenvolvimento regional.

As regiões estão para as instituições, são intimamente articuladas e as instituições estão envolvidas nas demandas sociais que estão postas e que são emergentes;

$\checkmark \quad$ Contribuem fortemente com o desenvolvimento regional e um retroalimenta o outro.

$\checkmark \quad$ Estão envolvidas nos órgãos e entidades da sociedade regional, como ACIC, conselhos municipais e estaduais;

$\checkmark \quad$ As instituições se tornaram uma referência para a comunidade em todos os sentidos;

$\checkmark \quad$ Contribuem com o desenvolvimento imobiliário ao entorno da universidade e no município;

$\checkmark$ Proporcionam formação nas mais diversas áreas do conhecimento;

$\checkmark \quad$ Possuem prestações de serviços por meio dos institutos para as prefeituras de toda região e até mesmo para fora do estado;

Possuem ensino de qualidade em uma formação profissional que tenha vínculo com a necessidade da sociedade;

$\checkmark \quad$ Envolvimento com a comunidade em projetos que atendem as demandas dos menos favorecidos;

$\checkmark \quad$ As decisões institucionais passam por representação da comunidade externa;

$\checkmark \quad$ Em todos os sentidos, em todas as áreas tem a busca da universidade como referência para poder ajudar a decidir o rumo e o caminho que se vai tomar;

$\checkmark \quad$ Promovem para Municípios cursos e seminários para os técnicos de toda a região dos Municípios;

$\checkmark \quad$ Relação muito próxima com o poder público municipal, nas diferentes áreas e para os diferentes problemas; 
$\checkmark \quad$ Entendem que as políticas públicas não contribuem com o crescimento e desenvolvimento da instituição quanto deveriam;

$\checkmark \quad$ Os projetos de extensão contribuem de maneira significativa nas diversas áreas, mas precisam avançar continuamente;

$\checkmark \quad \mathrm{Na}$ área da pesquisa, tem-se a pesquisa de ponta com reconhecimento internacional;

$\checkmark \quad$ Entendem que a atuação das instituições corresponde às expectativas da comunidade, mas sabe-se que precisa melhorar;

$\checkmark \quad$ Existe um certo distanciamento com desconfiança em relação ao setor empresarial

$\checkmark \quad$ As instituições possuem incubadoras tecnológicas;

$\checkmark$ Pesquisadores tem dificuldade de dialogar com a classe empresarial, porém já existe uma tentativa de aproximação.

$\checkmark \quad$ Promovem cursos que ajudam na mão de obra das estruturas comerciais da cidade;

$\checkmark$ O envolvimento da universidade é social, comercial e industrial, a universidade desenvolve o todo, além, de estar vinculada às estruturas existentes está bem vinculada aos municípios da região e a própria estrutura microrregional e associação, dos municípios da microrregião;

$\checkmark \quad$ Existe a promoção de eventos para ajudar a comunidade e a participação nos mais variados eventos;

$\checkmark \quad$ Procuram cada vez mais fazer uma série de serviços para a comunidade industrial, comercial e de serviços;

$\checkmark \quad$ Com relação aos projetos de extensão e pesquisa, os mesmos em grande parte, atendem os problemas regionais, porém não amenizam os problemas;

$\checkmark \quad$ Existe dificuldade de promoção de projetos devido ás limitações do ponto de vista orçamentário.

$\checkmark \quad$ Possuem política de inovação e estão envolvidas no projeto de inovação tecnológica da região;

$\checkmark \quad$ Precisam cada vez mais tentar fazer que o empresário enxergue a universidade como parceiro;

$\checkmark \quad \mathrm{Na}$ área da saúde, a formação inclusive nível de pós-graduação está nas instituições.

$\checkmark$ Conseguem promover o movimento econômico via projetos ou programas junto ao parque de inovação Tecnológico

$\checkmark \quad$ Promovem cursos de capacitação específica, encontro de empresas que vem e ocupam as instalações da instituição, ou individualmente atendendo as demandas nas empresas da Comunidade. 
Nas questões ambientais sempre são consultadas, fazem parte dos conselhos municipais. Nos conselhos não há evolução em um tema nessa linha sem envolver a universidade;

As Instituições estão sempre envolvidas a responder questões que tem algum impacto na sociedade seja social ou econômica, depende da área da atividade da pesquisa;

$\checkmark \quad \mathrm{Na}$ área de humanas, cursos de pós, a pesquisa tem um reflexo na formação no adensamento técnico-científico das pessoas de desenvolver senso crítico;

$\checkmark \quad$ Atuação da instituição corresponde aos anseios da sociedade, pois a sociedade é deficitária em muitas coisas, e se a instituição pudesse oferecer mais, com certeza, seria muito bem-vindo para sociedade mais a universidade tem suas limitações;

$\checkmark \quad$ Possuem programas de empreendedorismo e polo de inovação e propriedade intelectual e participam do movimento dos centros de inovação;

$\checkmark \quad$ A relação que a instituição tem com as empresas da região, faz com que elas venham de maneira espontânea conhecer a estrutura de laboratórios da instituição, assim como na busca de prestação de serviço,

$\checkmark \quad$ Possuem muitas demandas e diversas ações de prestação de serviço, seja em análise Laboratorial capacitação, locação de espaço para se fazer determinadas ações.

$\checkmark \quad$ Reconhecimento das pessoas que sem a Universidade não estariam na posição que se encontram socialmente;

$\checkmark \quad$ Precisam avançar na promoção do desenvolvimento regional, Possuem grandes e bons projetos de extensão e pesquisa, mas eles são muitos locais, precisam avançar, sendo que os projetos estão concentrados na área de ação comunitária;

$\checkmark \quad$ A interação com a comunidade regional, ocorre por meio de ações pontuais, mas mesmo assim a comunidade tem acesso aos serviços que são colocados à disposição;

Nos mestrados a interação maior por parte das pesquisas, pois possuem um porte maior, transcendem a questão da academia e vão muito para a comunidade e fazem essa inter-relação;

$\checkmark \quad$ Entende-se que não existe a nível estadual esta preocupação e nem Federal, com a formação superior;

A atuação da universidade, não é somente assistencialista, ou então unicamente voltada para a questão da redução da pobreza, mas se você conseguir fornecer mecanismos ou conseguir 
interagir em vários aspectos pensa-se que essa possa ser a repercussão na comunidade da universidade.

$\mathrm{Na}$ área de formação técnica acredita-se que consegue responder algumas expectativas, mas a universidade ainda está em dívida com a sociedade.

A maioria dos cursos são bem conectados com a população, desta maneira, imagina-se que as universidades vêm concretizando as suas missões;

A universidade tenta fazer o que é possível para atender a demanda da comunidade, porém às vezes as coisas escapam e que não é fácil atender tudo;

$\checkmark \quad$ A pressão da concorrência faz com que seja retomado um novo rumo, voltado para que a universidade vá atrás do seu cliente, com a concorrência a universidade tem que sair de dentro dela e buscar resultados fora.

$\checkmark \quad$ A universidade deve procurar suas demandas para a sociedade, ou a sociedade tem que vir propor essas demandas para instituição os dois setores têm que sentar juntos e pensar a região;

As universidades têm que se adiantar, mas infelizmente todas estão sempre andando atrás desse movimento e não na frente dele;

$\checkmark \quad$ A participação da parte empresarial ainda é muito ruim, sendo a participação mais na área de gestão do quê de colaboração;

$\checkmark \quad$ Não é o suficiente ensinar a parte teórica, a universidade tem a pesquisa e extensão que devem caminhar lado a lado, o aluno deve aprender pesquisando;

$\checkmark \quad$ Conhecendo da sustentabilidade das instituições, e do tripé ensino-pesquisa-extensão, pensa que tem de incluir disciplinas de pesquisa e extensão como obrigatórios na grade, mas a resistência é muito grande porque a universidade tradicional é difícil mudar; As universidades estão muito presentes na comunidade, pelas características da gestão das instituições, que não possuem donos, pois foram criadas por lei municipal;

A participação dos segmentos da comunidade na gestão, lhe dá um caráter comunitário de integração não apenas pelas ações que fazem, mas também pela sua gestão;

$\checkmark \quad$ Inicialmente foram criadas basicamente com a finalidade do ensino, a medida que foram crescendo se transformaram em universidades além do ensino, passaram a exercer sobretudo atividades de extensão e de pesquisa; 
Na extensão ocorre a inserção no desenvolvimento regional, pela participação da instituição;

Praticamente quase nada se faz sem a consulta e a presença da universidade em todos os seguimentos;

$\checkmark \quad$ Pensa-se que as instituições comunitárias não têm muitas condições de pesquisa básica de longo alcance, mais elas têm muita produtividade em pesquisas aplicadas, porem sua força na extensão e atividades de serviços é muito grande;

As instituições não possuíam muita influência comunitária, mas atualmente, possuem uma estrutura de expressão, com poder de organização, e com um contingente de alunos e grupos de professores altamente especializados, sobretudo quando focam em atividades de stricto sensu;

As instituições possuem pelos seus meios de comunicação influência na determinação de valores e rotas, inclusive políticas nas regiões;

$\checkmark \quad$ Atualmente o reitor da universidade e chamado para quase todas as grandes decisões, audiências públicas, sejam elas do poder executivo, do poder legislativo das câmaras de vereadores e inclusive nas ações do ministério público junto ao judiciário;

A presença das universidades é muito forte e possuem uma posição, não apenas pela conversa pelas palavras, mas sobretudo pelas publicações, pelos resultados de suas pesquisas;

$\checkmark \quad$ Estão muito engajadas nas suas regiões, e por isto que se pensa que a sociedade sente, que estas instituições são delas, da comunidade;

$\checkmark \quad$ Com relação a participação da comunidade nas decisões da instituição pensa-se que a comunidade regional decide sobre os destinos da instituição pela participação nos seus conselhos.

$\checkmark \quad$ Não há dúvida que todas regiões tiveram uma mudança e uma condição de desenvolvimento fantástica ao longo destes praticamente 50 anos, que as fundações foram criadas;

Talvez tenha sido a maior intervenção que a educação superior de SC tenha feito no estado, a formação de pessoas que permaneceram em suas regiões e que se não fossem estas instituições, não teriam condições de se aperfeiçoar, de se formar e melhorar sua condição profissional. Muito certamente teriam evadidos de suas regiões e se concentrado em grandes centros.

$\checkmark \quad$ Parece ser este o grande exemplo que um sistema educacional tem no estado, que a ACAFE tem das instituições comunitárias 
que permitiu ao estado de Santa Catarina um crescimento relativamente homogêneo.

$\checkmark \quad$ Existem limitações, porque tudo exige manutenção, mas a comunidade tem acesso permanente e irrestrito, nas bibliotecas não há restrição, os trabalhos dos Laboratórios, existem muitos Convênios enfim a relação é muito forte.

$\checkmark \quad$ Com relação às políticas públicas para o ensino superior, pensa-se que é sempre difícil manter parcerias com governo, é complicado porque juridicamente o estado, a união, municípios, e o estado Federado, não tem muito compromisso com os acordos que assumem;

$\checkmark \quad$ Com relação aos projetos de pesquisa e extensão, pensa-se ser uma parte fraca das instituições comunitárias;

As instituições comunitárias têm duas dificuldades fundamentais, a primeira é pessoas com condições de realmente fazer pesquisa e a outra, é recurso público, recurso em dinheiro, sem isso é muito difícil fazer, então se faz aquilo que se pode;

Atualmente as instituições comunitárias estão muito voltadas para a iniciação científica, e a iniciação científica não tem objetivo de resolver problemas regionais, embora muitas coisas possam nascer dali, mas tem o objetivo de fazer uma formação mais adequada para o profissional que se forma.

$\checkmark \quad$ Com relação a corresponder a expectativa da comunidade, se pensa que relativamente corresponde, se for comparada com as melhores universidades do mundo é das melhores universidades brasileiras;

$\checkmark \quad$ As instituiçõos estão presentes e a sociedade percebe, embora que gostariam que a instituições estivessem mais presentes.

\section{NAS ASSOCIAÇÕES EMPRESARIAIS}

$\checkmark \quad$ As universidades mantêm algum tipo de relação com as ACICs; As universidades são reconhecidas por desenvolverem papel extraordinário de apoio ao desenvolvimento econômico regional;

$\checkmark \quad$ A universidade desenvolve atividades de apoio empresarial nas áreas de gestão, qualificação e incorporação de novas tecnologias,

$\checkmark \quad$ O segmento empresarial está contemplado com as ações das universidades mediante ações especificas;

$\checkmark \quad$ Existe participação constante de ambas as partes nas atividades realizadas, que geralmente estão sempre conjuntas; 
Cada vez mais a universidade se faz presente, onde possui todo um grupo, um conjunto de grupo de pesquisas;

As universidades têm suma importância pelo que ela já foi, e pelo que será no futuro próximo;

$\checkmark \quad$ A influência que as universidades geram para a região é considerada se suma importância;

$\checkmark \quad$ As instituições contribuem de forma total para o crescimento regional, sendo uma forte geradora de mão de obra qualificada,

$\checkmark \quad$ Precisa ser conversado no que se aproxima em trabalhar dentro do aperfeiçoamento de alguns currículos já existentes, ou da criação de novos currículos;

$\checkmark \quad$ Com relação a prestação de serviços, se entra um pouco na questão do divórcio, que existe entre o mundo acadêmico e o mundo empresarial no Brasil;

$\checkmark \quad$ Precisa ser melhorado o guep que existe entre os dois mundos e precisa avançar,

$\checkmark \quad$ As universidades possuem mão de obra qualificada com Laboratórios equipados e bem montados;

$\checkmark \quad$ Compete ao mundo acadêmico e empresarial conversar no sentido de aumentar a interação, e criar um volume de negócio e de interação na parte de pesquisa;

$\checkmark \quad$ Percebe-se uma dissociação muito grande, o que é um problema cultural entre o mundo acadêmico e empresarial e que talvez, compete mais a Universidade pela sua definição, pelo seu conceito, em procurar o mundo empresarial;

$\checkmark \quad$ As atividades desenvolvidas pela universidade contemplam em parte as atividades empresariais, mas não tem um culpado;

Existe uma certeza de que se o setor empresarial se aproximasse mais das universidades, seriam bem recepcionados e a recíproca também é verdadeira;

$\checkmark \quad$ Os dois mundos ainda estão devendo;

$\checkmark \quad$ O empresário vive o momento, a universidade trabalha com o futuro, então talvez esta troca de comportamento seja o problema a ser enfrentado;

$\checkmark \quad$ Precisam trabalhar em conjunto, mas cabe à Universidade talvez o papel maior de pesquisador, de olhar mais o futuro, de fazer a frente, chamando a área empresarial para este problema que está começando a ver;

$\checkmark \quad$ O segmento empresarial ainda participa pouco das atividades promovidas pela universidade; 
As associações empresariais estão procurando ter uma conexão maior, mas existe a necessidade de uma interação mais forte;

As universidades auxiliam com relação aos cursos de extensão aprimoramento de uma maneira geral;

$\checkmark \quad$ A Universidade por ser mais pesquisadora, poderia procurar o mundo empresarial e a aproximação do outro lado do empresário com a universidade cabe as associações empresariais;

As lideranças do mundo acadêmico e as lideranças do mundo empresarial devem conversar, deve ser por aí a ponte de ter uma procura mutua;

$\checkmark \quad$ Com os parques científico-tecnológico em todas as regiões do estado, talvez possa ser este o momento do elo de ligação começar a fluir melhor;

Como é que a universidade vai aprimorar o currículo ou gerar novos currículos se ela não tem uma visão clara do meio empresarial;

$\checkmark \quad$ A universidade a partir da sua criação se torna um marco para o município em estar promovendo, formando, capacitando, profissionais que atuam nos municípios;

$\checkmark \quad$ A massa formada se torna a massa crítica que a universidade formou;

$\checkmark \quad$ As universidades conseguem dar ao município uma estatística de crescimento tanto na área de serviços ou na área do Comércio e Indústria;

$\checkmark \quad$ Além da graduação surgem cursos de pós-graduação, os mestrados e doutorados sempre impulsionando e valorizando o mercado;

As atividades desenvolvidas pelas Instituições são de conhecimento das associações que são convidadas a estar presente ou representada;

As instituições possuem de maneira muito forte, a questão de palestras focadas para determinadas áreas;

Os eventos que a universidade promove são voltados para comunidade, pois são Universidades comunitárias;

$\checkmark \quad$ Tem o compromisso por ser comunitária e precisa desse compromisso para com a comunidade, e isso cumpre rigorosamente e faz muito bem isso;

$\checkmark \quad$ Possuem condição de promover e desenvolver as pessoas para atuarem dentro de grandes empresas;

$\checkmark \quad$ A universidade tem atuado forte e desta maneira ela é uma mola propulsora é um lubrificante feito para girar a roda do município 
São nas universidades que se vai encontrar técnicos e conhecedores sobre determinados assuntos, que poderão ajudar com o conhecimento institucional

As associações se garantem em propor várias situações, porque sabe que pode contar a universidade com o profissional que está lá dentro com aquele Professor, com aquele Doutor com aquele aluno;

Às vezes pensa-se a Universidade somente na graduação ou pósgraduação, mas tem o lado do ensino médio, o jovem aprendiz que é uma área social fortíssima de atendimento às empresas e atendimento à legislação, onde as empresas estão muito abertas;

$\checkmark \quad$ Uma das atividades que existe na Universidade são as empresas Júnior, a qual tem o foco de promover projetos que venham dar tanto ao micro, pequeno e médio empresário, ações para melhoria de sua performance no mercado;

As universidades conseguem contemplar a satisfação da comunidade empresarial do município e região;

Pensa-se que a universidade contribui com o desenvolvimento, principalmente quando existe a responsabilidade na construção do profissional, trazendo a prática para dentro da realidade dos acadêmicos isto faz a diferença no resultado;

$\checkmark \quad$ As atividades realizadas pela universidade contemplam muitas demandas da parte empresarial, através dos cursos;

Com relação a prestação de serviço ainda é pouca, tem empresários que buscam, mas são poucos a busca ainda é um pouco frágil;

$\checkmark \quad$ Para aumentar a interação entre a universidade e a parte empresarial falta divulgação, muitas pessoas que estão iniciando um trabalho, os novos empreendedores eles precisam de orientação e não sabe onde buscar na universidade;

As instituições ainda são muito de portas fechadas para conhecimento acadêmico, a produção, pós-graduações, mestrados, aos debates em sala de aula ficam em sala de aula;

O envolvimento da instituição, ainda é muito tímido, a universidade precisaria se envolver mais;

A universidade precisaria formar alunos que estejam conectados com os problemas sociais desenvolvendo propostas para resolver; Talvez o fato da universidade não estar tão linkada com comunidade, seja um pouco a vontade do professor, ou falta de tempo ou incentivo; 
$\checkmark \quad$ Existem os problemas que cada um pensa por si, Universidade e a sociedade empresarial, e assim de uma forma geral é cultural, a relação entre universidade e Associação;

A universidade é como um polo que acaba atraindo investimentos, atraindo pessoas e concentrando uma população regional, tornando os municípios pólos regionais, mas falta o link entre universidade e o empreendedor.

A universidade pode ser considerada um vetor de desenvolvimento, mas ela não é o canal de desenvolvimento é o contato, o setor que atrai acadêmicos de outras regiões e isto fomenta o mercado, mas talvez, por ser uma universidade comunitária ela foca no assistencialismo;

$\checkmark \quad$ Não só o empresário tem que buscar a universidade, mas a universidade tem que buscar o empresário;

$\checkmark \quad$ Talvez falte às universidades abrir as portas para que as empresas busquem algo lá dentro;

$\checkmark \quad$ Precisa ser fomentada ao professor, a visão empreendedora para que eles possam independente da matéria e do curso, passar aos alunos a importância do empreendedorismo;

$\checkmark \quad$ Existe um distanciamento, uma barreira entre a universidade e a sociedade, ocorre que mesmo tendo a sociedade liberdade para direcionar demandas de problemas para que a universidade possa contribuir com soluções, não se consegue mensurar se isto acontece;

$\checkmark \quad$ Não se vê a universidade procurar a sociedade, não tem a questão comercial, você não vê a universidade buscar demandas na sociedade;

A análise deste distanciamento serve como alerta para ambas as partes, pois se tem a liberdade de dispor as ideias, falta é a forma de como propor;

$\checkmark \quad$ Considera se que existe um entrosamento e um clima de boa vontade entre as partes, porém falta uma proximidade maior.

Pensa que a iniciativa poderia ser da própria universidade em levantar a disponibilidade e oferecer aos empresários, pois tem potencial para desenvolver projetos e atividades que envolvam mais a cidade e a região;

$\checkmark \quad$ Pensa que a comunidade não sabe o que tem dentro das universidades e nem tão pouco tem noção do que poderia ser oferecido para a comunidade; 
As Universidades prestam um bom serviço com bons profissionais que estão se formando e orientados pelos professores experientes;

Com relação a contribuição da universidade para o desenvolvimento da região, não se tem dúvida que contribuem e podem contribuir muito mais;

$\checkmark \quad$ As universidades prestam o serviço muito importante para todos da região, e contribuem bastante para o desenvolvimento, prestando serviços excelentes para comunidade, e contribuindo com crescimento dos movimentos da cidade.

As instituições estão perdendo muito espaço e dando oportunidade para se criar outras universidades;

Com relação ao segmento empresarial estar sendo atendido pelas atividades da universidade, pensa-se que está aquém daquilo que poderia ser considerado como desejável;

Com relação a interação da comunidade empresarial e da universidade, talvez exista falha da própria comunidade empresarial em levar as demandas;

Talvez esteja faltando solicitar mais do mundo empresarial, mas em serviços mais entrosamento com a comunidade acadêmica, este entrosamento é teórico;

$\checkmark \quad$ O que precisa ser melhorado é a interface entre a universidade e a região onde precisa se abrir um pouco mais, mostrar melhor o que oferece;

$\checkmark \quad$ Atualmente perdem muitos alunos para as outras universidades para os cursos a distância, para faculdades privadas por falta de uma comunicação maior;

Possui uma excelente infraestrutura e um bom nível de professores são boas em praticamente tudo, em laboratórios que dificilmente alguma outra universidade possui;

$\checkmark \quad$ Precisam fazer um esforço de mostrar para a comunidade seu verdadeiro potencial;

Pensa-se que pela extensão e pela potência que são as instituições, poderiam estar fazendo muito mais em prol da sociedade, mas são bem atuantes, e ninguém pode reclamar, mas são bem participativos se envolvem bastante com a comunidade, pensa-se que não teria com o que reclamar nesse sentido;

Dentro das ações que promovem, destaca-se a formação de mão de obra e principalmente o conhecimento trazem, por que, trabalhar com pessoas que tem um grau de instrução maior, em relação a uma pessoa que não teve esta oportunidade é diferente; 
$\checkmark \quad$ Se pegar uma região que não possui uma faculdade e uma região que possui, você percebe que o desenvolvimento da região que tem a oportunidade de possuir uma faculdade, é talvez mais estruturado e tenha um desenvolvimento mais sólido.

$\checkmark \quad$ Com relação aos segmentos empresarias está contemplado com as atividades da instituição, pensa-se que na parte da indústria ainda não tem muita interação;

$\checkmark \quad$ As universidades contribuem em várias ações com os municípios, mas pela potência que são poderiam contribuir muito mais com a sociedade, poderia ajudar mais;

$\checkmark \quad$ Existe falha da universidade, mas se tem noção que existe a falha por parte da associação, pensa-se que de ambas as partes existe a dificuldade de se procurarem um ao outro e interagirem;

$\checkmark \quad$ Pensa-se que existe uma lacuna, não há uma procura entre as partes, mas se acredita que se houver esta necessidade os dois lados vão estar abertos, e pode haver uma proximidade sem dificuldades nenhuma, em um ambiente maior. 
ANEXOS 


\section{ANEXO A}

Mestrando - Janir de Quadra Paim

Orientadora - Profa. Dra. Cristina Keiko Yamaguchi

Coorientador: Prof. Dr. Miguelangelo Gianezini

\section{ENTREVISTA COM GESTOR DA IES}

1) Há quanto tempo está na Instituição?

2) Em quais funções e atividades já atuou na instituição?

3) Como você percebe o envolvimento da instituição junto à região onde está inserida a universidade?

4) Você considera a sua Instituição, como um agente promotor do desenvolvimento regional?

5) Quais seriam as políticas macros da Instituição que subsidiam o envolvimento com a comunidade regional?

6) Como ocorre a interação IES X Comunidade regional?

7) Como identifica a participação da comunidade regional nas decisões institucionais?

8) O inverso, como percebes as ações da instituição influenciarem nas decisões da comunidade regional? Quais

9) Com relação as atividades de extensão existem a promoção destas atividades para a comunidade local e regional? Quais?

10) A instituição possui atividades de extensão assistencial? (Clinicas, casa da cidadania, assessorias e outras) fale sobre

11) A comunidade regional conhece a UNIVERSIDADE? A comunidade possui acesso e transito pelo campus?

12) Como ocorre a relação da IES com o poder público municipal?

13) As Políticas públicas com relação ao ensino superior, contribuem com o crescimento e desenvolvimento da instituição? (ensino, pesquisa e extensão)

14) Os programas e projetos de pesquisa e extensão atendem e conseguem resolver ou amenizar os problemas regionais nas diversas áreas?

15) A atuação da instituição está correspondendo a expectativa da comunidade organizada da região? Em que sentido?

16) Com relação a pesquisa em inovação, a instituição possui politicas próprias a inovação? Quais? Possui incubadora, núcleo de patentes, projeto de empreendedorismo, etc. 


\section{ANEXO B}

Mestrando - Janir de Quadra Paim

Orientadora - Profa. Dra. Cristina Keiko Yamaguchi

Coorientador: Prof. Dr. Miguelangelo Gianezini

A proposta da pesquisa intitulada "Papel das universidades comunitárias de ensino superior de Santa Catarina para o desenvolvimento regional", buscará identificar como a comunidade organizada percebe a interação regional das Instituições Comunitárias de Educação Superior - ICES de Santa Catarina.

\section{Questionário para auxiliar na entrevista com as representantes entidades de classes}

1) Há quanto tempo exerce a função de representante deste segmento empresarial?

2) Você conhece a Universidade?

3) Qual sua opinião sobre as atividades desenvolvidas pela universidade (instituição) em prol da comunidade regional?

4) Você conhece algumas das atividades desenvolvidas pela universidade (instituição)?

5) $\mathrm{Na}$ sua percepção como a universidade contribui para o desenvolvimento e o crescimento regional?

6) O segmento empresarial que você representa é contemplado com as atividades promovidas pela universidade? De que maneira?

7) O segmento empresarial que você representa participa das atividades promovidas pela universidade?

8) A Associação empresarial possui representatividade nas decisões da Universidade? Se sim de que maneira? É importante por que? 


\section{ANEXO C: PLANILHA DE COLETA DE INFORMAÇÕES}

Mestrando - Janir de Quadra Paim

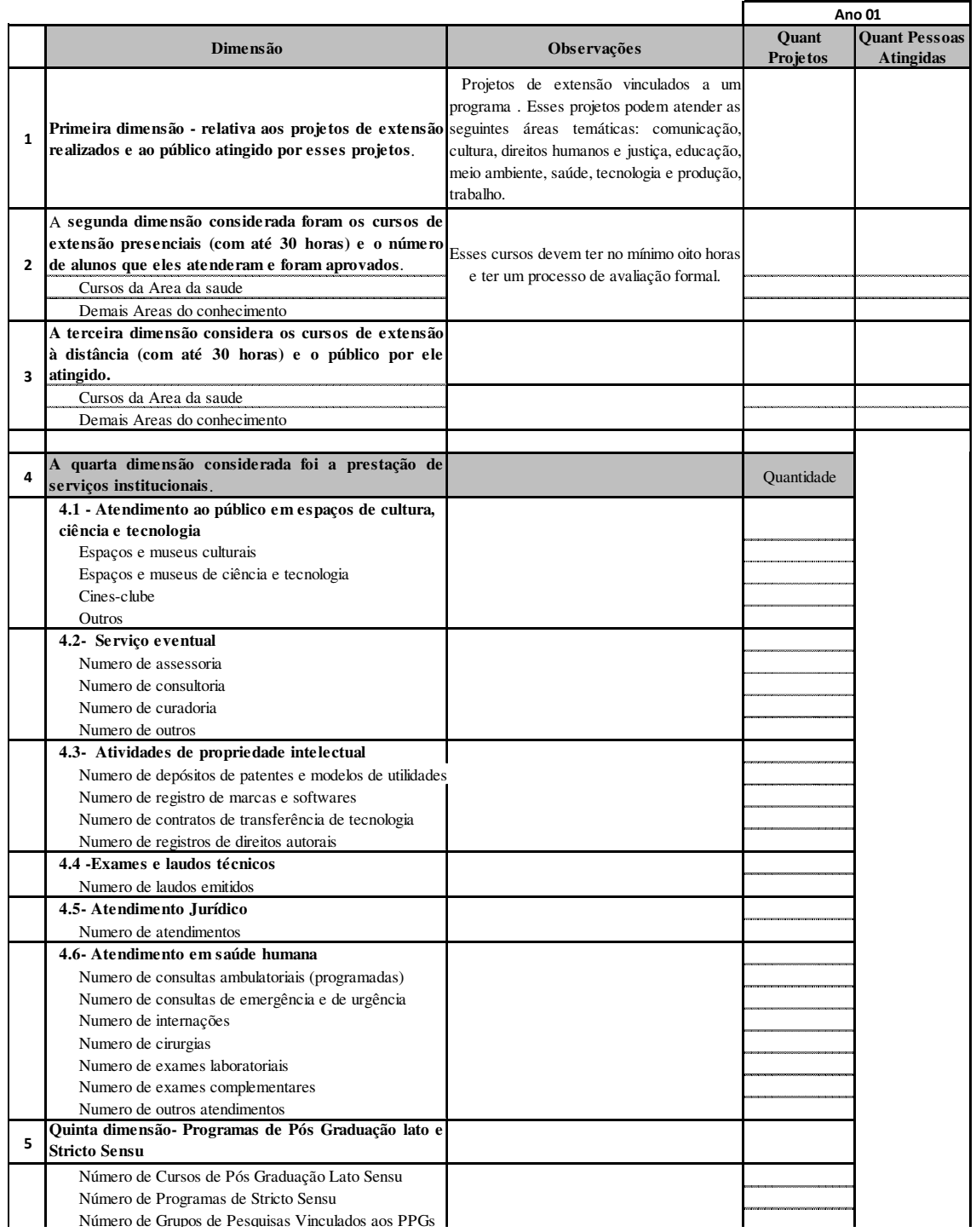

